Impact of India's demonetization on domestic agricultural markets

Nidhi Aggarwal and Sudha Narayanan

Indira Gandhi Institute of Development Research, Mumbai November 2017 


\title{
Impact of India's demonetization on domestic agricultural markets
}

\author{
Nidhi Aggarwal and Sudha Narayanan
}

Email(corresponding author): sudha@igidr.ac.in

\begin{abstract}
In this paper we estimate the impact on domestic trade in agricultural commodities of India's demonetization exercise that invalidated $86 \%$ of the currency in circulation. Using data on arrivals and prices from close to 3000 regulated markets in India for 35 major agricultural commodities for the period 2011-2017, we focus on short term effects up to 3 months after demonetization, tracking both the impact and recovery. These 35 commodities account for an overwhelming share of land under cultivation and value of production and hence are representative of Indian agriculture in more than one sense. Using earlier years as comparison years, we use a combination of difference in differences techniques and synthetic control methods to identify the causal impact of demonetization. We find that demonetization has displaced domestic agricultural trade in regulated markets by over $15 \%$ in the short run settling at $7 \%$ after recovery at the end of the 90 day period after demonetization. Trade in perishables was displaced to the extent of $23 \%$ in the week following demonetization. It recovered slightly by the end of 90 days, but was still 18\% lower than the usual. Most of this decline is on account of the significant decline in prices rather than of arrivals, which appear to have recovered over a period of three months. There are significant differences across commodities but almost all of these are in expected ways. The impacts are sharpest for kharif crops where government intervention is minimal or absent and for perishables and least for crops where farmers are well organized or commodities which governments actively procure. Robustness checks and falsification tests support our findings to a large extent. Overall, it seems to be the case that the monetary contraction embodied in demonetization significantly impacted arrivals and prices, though the price impacts are perhaps more lasting. The findings from this analysis and anecdotal evidence from field visits suggest that the impacts of demonetization potentially have effects that could last beyond the immediate impact.
\end{abstract}

Keywords: demonetization, agricultural markets, India, difference-in-differences, synthetic control

JEL Code: E5, E51, Q02, Q11, Q13

\section{Acknowledgements:}

We thank without implicating Anisha Chaudhary for research assistance and participants of a research workshop at IGIDR and participants at FLAME University for useful discussions, comments and suggestions. 


\title{
Impact of India's demonetization on domestic agricultural markets
}

\author{
Nidhi Aggarwal*1 and Sudha Narayanan ${ }^{2}$ \\ ${ }^{1}$ Assistant Professor, Indian Institute of Management, Udaipur, India. e-mail: nidhi.aggarwal@iimu.ac.in \\ ${ }^{2}$ Associate Professor, Indira Gandhi Institute of Development Research (IGIDR), Mumbai, India. e-mail: \\ sudha@igidr.ac.in
}

November 6, 2017

\begin{abstract}
In this paper we estimate the impact on domestic trade in agricultural commodities of India's demonetization exercise that invalidated $86 \%$ of the currency in circulation. Using data on arrivals and prices from close to 3000 regulated markets in India for 35 major agricultural commodities for the period 2011-2017, we focus on short term effects up to 3 months after demonetization, tracking both the impact and recovery. These 35 commodities account for an overwhelming share of land under cultivation and value of production and hence are representative of Indian agriculture in more than one sense. Using earlier years as comparison years, we use a combination of difference in differences techniques and synthetic control methods to identify the causal impact of demonetization. We find that demonetization has displaced domestic agricultural trade in regulated markets over $15 \%$ in the short run settling at $7 \%$ after recovery at the end of the 90 day period after demonetization. Trade in perishables was displaced to the extent of $23 \%$ in the week following demonetization. It recovered slightly by the end of 90 days, but was still 18\% lower than the usual. Most of this decline is on account of the significant decline in prices rather than of arrivals, which appear to have recovered over a period of three months. There are significant differences across commodities but almost all of these are in expected ways. The impacts are sharpest for kharif crops where government intervention is minimal or absent and for perishables and least for crops where farmers are well organized or commodities which governments actively procure. Robustness checks and falsification tests support our findings to a large extent. Overall, it seems to be the case that the monetary contraction embodied in demonetization significantly impacted arrivals and prices, though the price impacts are perhaps more lasting. The findings from this analysis and anecdotal evidence from field visits suggest that the impacts of demonetization potentially have effects that could last beyond the immediate impact.
\end{abstract}

Keywords: demonetization, agricultural markets, India, difference-in-differences, synthetic control

JEL Classification Codes : E5, E51, Q02, Q11, Q13

\footnotetext{
${ }^{*}$ We thank without implicating Anisha Chaudhary for research assistance and participants of a research workshop at IGIDR and participants at FLAME University for useful discussions, comments and suggestions.
} 


\section{Introduction}

On November 8, 2016, the Government of India declared that two widely held denominations of the Indian Rupee - the Rs.500 and Rs.1000 notes - would cease to be legal tender after midnight. ${ }^{1}$ In that one act, as much as $86 \%$ of the money in circulation was deemed illegal tender, engineering a currency squeeze that has few parallels elsewhere in recent times. In the days that followed, as people across the country deposited these two denominations in banks, while the central bank of India began replacing these with new currency. By March 31, 2017, however, the value of currency in circulation was only $74 \%$ of that on the eve of demonetization (Figure 1).

While demonetization was expected to have economy-wide impact, it was anticipated that it would affect the informal sector and agriculture more, given the latter's heavy reliance on cash for daily transactions. In this paper, we assess the impact of demonetization on domestic agricultural markets with a specific focus on government regulated markets (or mandis), where typically farmers sell their produce to traders via intermediaries. ${ }^{2}$ We estimate the value of domestic agricultural trade that was displaced on account of demonetization and examine the underlying drivers of these impacts - specifically whether these impacts manifest via volumes traded or via prices.

Our motivation for investigating the impact on agricultural trade is manifold. We recognize that the impacts on agriculture trade and prices are at best intermediate, proxy indicators that fall well short of estimating the welfare implications for farmers, in terms of either their incomes or expenditures. However, given that nationally representative data on farmer incomes are not routinely collected ${ }^{3}$ and data from expenditure surveys will likely take a while, the impacts on domestic agricultural trade offer the best proxy for farmer receipts. This is especially since most farmers do not stock or store most cash crops beyond a few weeks. Second, even with regard to impacts on transaction volumes and prices in the mandis, while most commentators have articulated potential impacts on this sector, there has only been anecdotal evidence from academics and journalists during the weeks following demonetization. Limited research based on secondary data are equivocal. Several observers in fact claimed soon after demonetization, that trade would not be impacted since many transactions are cheque based and that these fears of an implosion of agricultural trade domestically are exaggerated. For example Chadha et al. (2017); Chand and Singh (2016) report using secondary data on mandi prices that demonetization may not have had an adverse impact. Others find that trade in these mandis reduced, at least in the immediate

\footnotetext{
${ }^{1}$ Circular Number RBI/2016-2017/122 DCM(plg)No.1226/10.27.00/2016-17 issued on November 8, 2016. See Reddy (2017); Ghosh et al. (2017) for accounts of demonetization.

${ }^{2}$ These intermediaries are licensed market functionaries who mediate transactions, for a fee, between farmers and traders and are typically called commission agents or brokers.

${ }^{3}$ National surveys of farmer incomes are available from the NSS 70th and 59th Rounds, conducted in 2013 and 2003 respectively. There have been no other systematic data collection efforts to gauge farmer incomes in India thus far.
} 
aftermath of demonetization, (Aggarwal and Narayanan, 2016; Banerjee and Kala, 2017). ${ }^{4}$ Given these conflicting perspectives, our study aims to shed light on this debate using a larger coverage of crops, markets, time periods and appropriate identification strategies that support causal inference. Third, despite agriculture's declining importance as a contributor to GDP, about $14.9 \%$ of the country's GDP, about half of all people derive livelihoods from agriculture (Government of India, 2016b). Agriculture is known to impact overall economic growth as a result, an observation made with predictable regularity in most discussions of economic growth in India. We can thus assess the recent slowdown in growth rates in India's Gross Domestic Product (GDP), in the quarters following demonetization, in light of the impacts on India's agricultural sector.

As much as we have immediate interest in quantifying the impacts of demonetization for its own sake, this effort enables us to uncover some understudied relationships between macroeconomic phenomena and agriculture in the context of developing countries and transition economies. That macroeconomic policy can have impacts on the (real) sectors, that may not be well integrated into the modern economy, is an old concern.${ }^{5}$ Other early theoretical work on the impacts of monetary policy emphasize that it can have non-neutral effects on agriculture, with a restrictive policy depressing agricultural prices and incomes (See for example Chambers (1984); Belongia (1991); Diaz-Bonilla and Robinson (2010) for reviews). Existing empirical evidence too suggests that across a range of contexts, market structures and time periods there exists a statistical relationship between money supply and agricultural prices, just as theoretical work on financial-agricultural markets predict. While monetary policy was deemed to influence agriculture largely through overall prices and interest rates, a sudden monetary contraction could, in the short run, work primarily through shifting demand and supply on account of reduced cash held for transactions. In scale and scope, the Indian experience of demonetization is perhaps larger and deeper than any other in recent recorded history. ${ }^{6}$ Further, the unanticipated nature of the event offers a greater scope to better identify empirically and statistically the consequences of monetary contraction on economic activity in informal sectors over the short run. ${ }^{7}$

In this paper we use data on arrivals and prices from 2953 regulated markets in India for 35 major agricultural commodities for the period 2011-2017. These 35 commodities account for an overwhelming share of land under cultivation and value of production and are hence representative of Indian agriculture in more than one sense. Using earlier years as comparison years, we use a combination of difference-in-differences techniques and synthetic control methods to construct appropriate counterfactuals for 2016-17, i.e., the "treatment" unit/ year, elaborated later in the

\footnotetext{
${ }^{4}$ Banerjee and Kala (2017), for example, report that sales of agricultural commodities was $83 \%$ of the predicted value.

${ }^{5}$ Chambers (1984); Chambers and Just (1982); Schuh (1974) are early examples. Historical studies on impacts of demonetization and more generally monetary contraction in other countries are byHamilton (1987); Miskimin (1964); Ciriacy-Wantrup (1940).

${ }^{6}$ Myanmar's demonetization in 1987 that invalidated $80 \%$ of the currency in circulation without a smooth transition is by far the most like the Indian experience.

${ }^{7}$ See for example, internet searches on this issue in Figure 2.
} 
Figure 1 Value of Notes in Circulation in India: July 2016 to March 2017

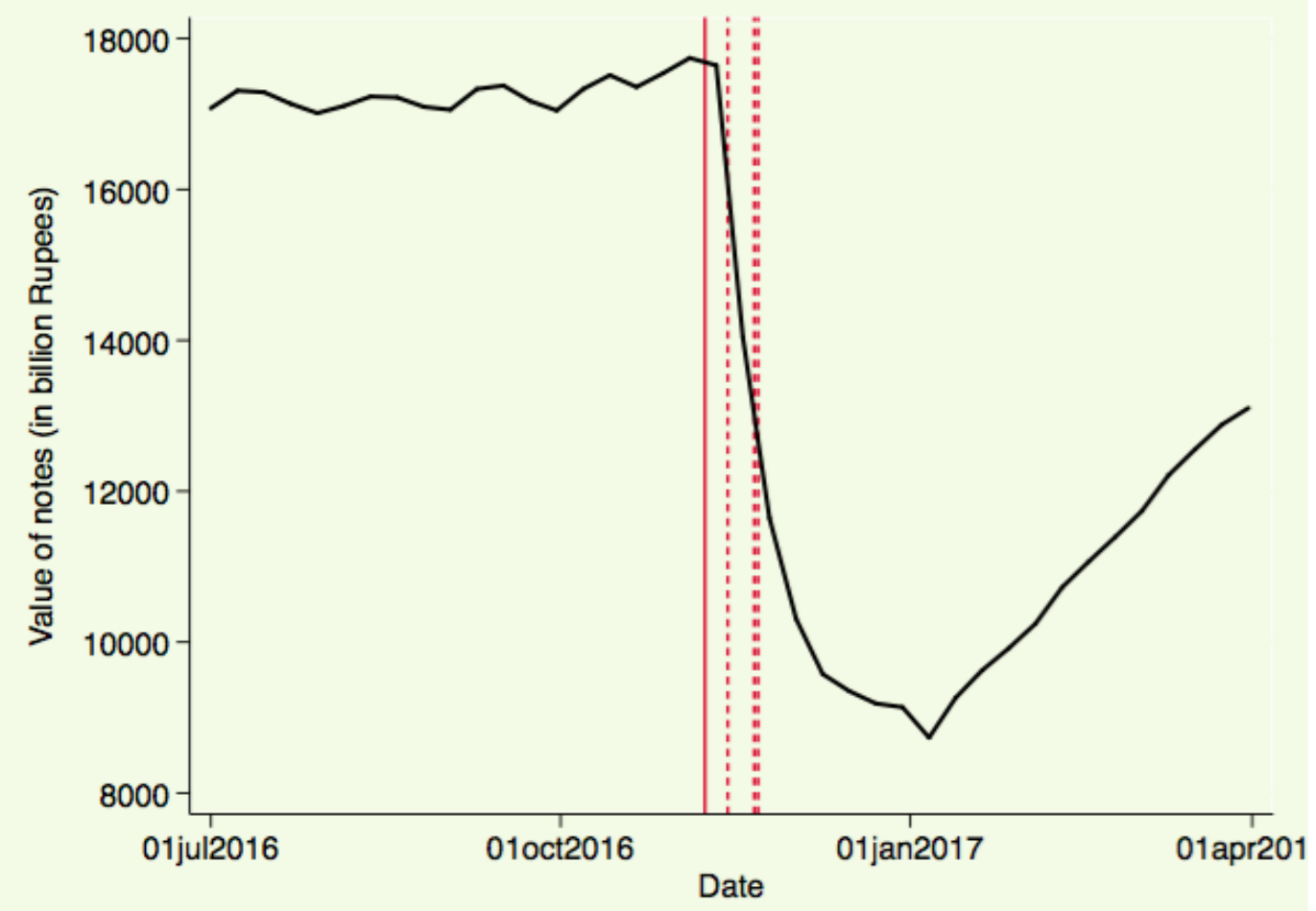

Source: Reserve Bank of India.Table 2, Liabilities and Assets, Accessed September 30, 2017. The vertical line represent dates of relevant notifications when currency withdrawal restrictions were eased.

Figure 2 Trend in internet searches on Google for demonetization

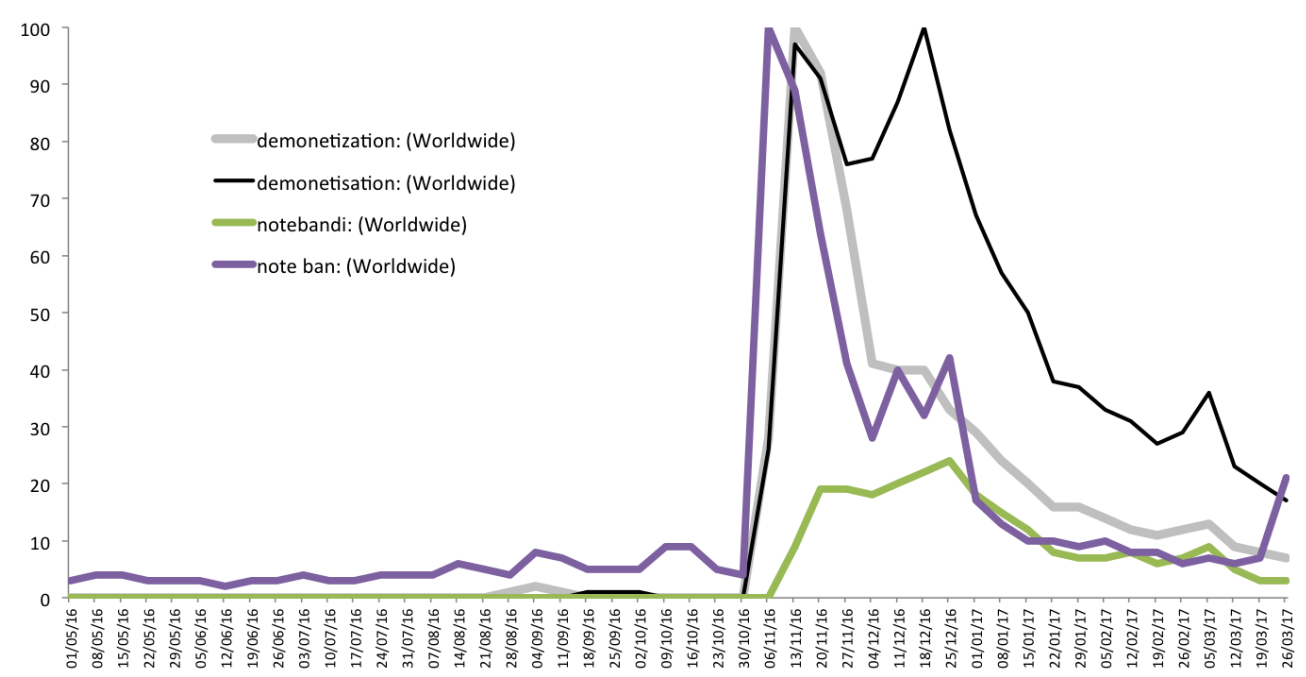

Notes: These are weekly data with 100 denoting the highest number of searches, notebandi is the word for note ban in Hindi, the most commonly spoken language in India. October 15, 2017. 
paper. We find that demonetization has displaced domestic agricultural trade in regulated markets over $15 \%$ in the short run settling at $7 \%$ after recovery at the end of the 90 day period after demonetization. ${ }^{8}$ Most of this decline is on account of the significant decline in prices rather than of arrivals, which appear to have recovered over a period of three months.

There are significant differences across commodities but almost all of these are in expected ways. Trade in perishables was displaced to the extent of $23 \%$ in the week following demonetization. It recovered slightly by the end of 90 days, but was still $18 \%$ lower than the usual. As expected, most of this decline in value of perishables came from decline in prices, directly hitting farmers' income. Tomato prices declined to as much as $47 \%$ as a result of demonetization. So was the case with lemon prices which declined by $46 \%$ in the week following demonetization. Even within non perishables, traded value in commodities such as soyabean got eroded to the extent of $69 \%$ as a result of demonetization. However, unlike perishables, the main source of this decline was on account of decline in arrivals, where farmers had no choice but to hold their stock for some more days to cope with the cash crunch and low demand.

Overall, the impacts are sharpest for kharif crops where government intervention is minimal and for perishables where farmers did not have the choice to store. The impacts are least for crops where farmers are well organized or where governments actively procure. Robustness checks and falsification tests support our findings to a large extent. Thus, it seems to be the case that the monetary contraction embodied in demonetization has impacted arrivals and prices, though the price impacts are perhaps more lasting. These findings help interpret the growth performance of the Indian economy since demonetization and helps anticipate the welfare consequences for farmers.

The paper is organized into six sections. Following this discussion, we describe the context of domestic agricultural trade in India. We then conceptualize the pathways through which demonetization is expected to impact domestic agricultural trade. Section 3 discusses the data used and empirical strategy. Section 4 discusses the results, with Section 5 devoted to checking the robustness of results. Section 6 summarizes these results and discusses coping strategies.

\section{The context of agricultural transactions in India}

Domestic agricultural trade in India typically occurs in designated markets declared under the Agricultural Produce Marketing Committee Act (APMC Act). Historically, farmers were mandated to trade in these markets to licensed intermediaries. Although several states have reformed this law allowing private trade, contract farming and direct procurement, for most commodities, a significant proportion of trade passes through these mandis, even if the first trade may be a sale by a farmer to an itinerant trader or within the village. In a typical process at a regulated mandi, a farmer brings his/her produce to the mandi, takes it to the commission agent of his choice, unloading the

\footnotetext{
${ }^{8}$ Our other models with alternate specifications predict worse impacts of around $20-30 \%$ settling to around $10-15 \%$ by the end of 90 days.
} 
produce there (Aggarwal et al., 2017). Each lot is identified and bidding is for each lot. During the time designated for trade, prospective buyers, including traders and processors, each of whom holds a licence to trade in the specific mandi, visits the agent's premises, examines the quality of the produce and quotes a bid price. The bidding is either closed tender, where they bid is private and written down on a paper slip or computer or it is through an auction. The former dominates commodities that see large daily arrivals. At the end of the trading window the highest bid price is declared as the winning bid. The farmer has a choice to reject the bid if he does not like the price, in which case his lot is placed for bidding on the next trading day in the mandi. If the farmer accepts the price, his produce is weighed and a sales bill is generated. The trader pays the commission agent, and the commission agent, after deducting his commission and the mandi fee, pays to the farmer, mostly in cash. In the above process (for non-perishables), payment occurs at two stages: from the trader to the commission agent, and from the commission agent to the farmer. Traders typically do not pay the commission agents immediately, but buy the commodity on credit. The payment is made to the commission agent between fifteen days to six months of time. The commission agent pays to the farmer, either upfront, or within one or two days, after taking account the interest cost (for paying in advance), and deducting for loans that he may have provided to the farmer in the past.

Virtually all of these transactions are cash-based and although cheque payments and direct bank transfers are increasingly being used by processors, this still forms a small portion of transactions (Aggarwal et al., 2017). As of 2015, there were 6746 such regulated markets (2479 of them termed primary markets and the rest called submarket yards or minor market), with each district in the country having at least one such market (Government of India, 2016b). ${ }^{9}$ The early rationale for a regulated system of markets was to reduce the transactions costs for farmers and ensure that farmers did not have to travel too far to sell the produce. A second reason was to ensure that there is regulatory oversight of farmer-to-trader sales in order to protect the interests of the farmers, i.e., protect them from exploitative terms and conditions. The context we study therefore involves a large number of heterogeneous markets - in terms of size, commodities traded, location and so on. Different states allow private markets direct trade outside the mandi regularly. Despite heterogeneity and the existence of credit relations (long terms relationships), cash transactions dominate mandi-based trade and mandi is the key channel for a bulk of the produce.

\subsection{Conceptual Pathways and Hypotheses}

What is the likely impact of demonetization on domestic agricultural markets, as represented by mandi based trade? Given the context, we expect that a shared shortage of liquidity reduces demand for commodities because commission agents (or even traders if they pay upfront) are unable to pay

\footnotetext{
${ }^{9}$ There are also a reported 26519 rural markets - primary and wholesale that are not regulated Government of India (2016b).
} 
the farmers in cash. The traders themselves may face a demand shock if their buyers are also cash constrained or are only willing to purchase on credit or bank based payments. In the case of bank based payments, traders and commission agents might still face a cash constraint because even with banks, there were severe restrictions on access to liquidity.

For instance, post-demonetization, restrictions on cooperative banks, a key institution in rural finance, were not allowed to accept deposits of old currency, even in exchange for new currency. Withdrawal and exchange limits on new currency were in force for weeks after demonetization (Appendix C). It was not until November 21, 2016, ${ }^{10}$ that farmers were granted some latitude to withdraw upto Rs.250000 per week in cash from specific deposit accounts. Traders registered with APMC markets / mandis were allowed to withdraw, in cash, Rs 50,000/- in a week with some conditions (Figure 1). ${ }^{11}$ Despite this, reports from that time suggest that new currency notes were slow to reach rural areas and cash crunch. Access to cash through Automatic Teller Machines (ATM) and banks has not been easy. Our own field visits to prosperous regions, near the national capital, exporting high quality rice revealed that even with a number of bank branches and ATMs in the town, there was a shortage of cash. ${ }^{12}$ It is possible that many farmers accept bank based payments, although there are indications that suggest that this large scale shift is unlikely to have occurred.

From the supply side, while one would expect that farmers want to sell immediately after harvest, as is typical, it is possible that anticipating a fall in prices farmers are holding back produce from sale. Alternatively it could be that the transactions costs of bringing produce to these mandis, including labour costs and transportation, impinges on farmers who are short of liquidity, who are then forced to postpone their journey to the market, potentially overriding an urgent need to sell produce in order to obtain cash if they were short of cash. ${ }^{13}$ Either or both of these has the effect of contracting supply. These imply the following hypotheses:

- With a contraction of both demand and supply we would expect the volumes of mandi trade to decline, especially for non-perishable commodities where the farmer has a choice to store it and sell at a future date. This effect would manifest in the data as reduced mandi arrivals. This may not happen for perishables, where storing is not an option available to the farmer. Nor would one expect strong impacts for commodities that either see government procurement or are vertically coordinated and where transactions are based on contracts, rather than spot markets.

\footnotetext{
${ }^{10}$ Circular Number: RBI/2016-2017/146; DCM(plg)No.1323/10.27.00/ Figure 1 marks these dates with red dashed lines.

${ }^{11}$ Circular Number: RBI/2016-2017/148; DCM(plg)No.1345/10.27.00/; Loans for the following cropping season were permitted around the same time.

${ }^{12}$ These field visits were to regulated markets in Gannaur (Haryana) and Azadpur (Delhi) during November 29December 1, 2016. Field visits involving conversations with farmers included Karnataka in June and July, 2017; Madhya Pradesh, March, 2017 and Tamil Nadu, March 2017.

${ }^{13}$ We expect that this latter effect would be weak given the shared scarcity of cash.
} 
- The prediction for prices is less obvious. If as described above, both demand and supply contract, then the impact on prices depends on which effect is stronger, i.e., on their price elasticities. If it is the former (latter), one would expect prices to fall (rise). In some cases, especially for perishables, where storing the commodity is not an option, or if the farmer is in an urgent need of the money, there would be a decline in the prices. All of these impacts would naturally vary across commodities and the nature of government intervention and market structure in each of these.

We test the above two hypotheses using data on mandi arrivals and prices. However, the impacts on both arrivals and prices could vary widely across mandis. Our hypothesis is that mandis that trade mostly in cash or have limited penetration of banks and are relatively less connected to urban areas are likely to be more affected. ${ }^{14}$ According to the Report of the Committee on Medium-term Path on Financial inclusion, in June 2015, the number of branches per 100,000 of population in rural and semi-urban areas in India was 7.8, less than half the number in the urban and metropolitan areas (18.7). The median global value as per the data from the World Bank in 2015 was 12.62. ${ }^{15}$ It could also be the case that farmers don't simply choose whether or not to sell in the mandi but pick the mandi they wish to go to. Our field visits in the aftermath of demonetization suggest that some farmers coped with the cash constraints by choosing to sell in nearer, rather than their preferred distant mandis. This diversion of trade to mandis closer to the point of production could imply that smaller markets closer to production centres saw lower decline in arrivals relative to larger market. However, the rate of recovery in these markets is expected to be slower than the larger markets.

There are several reasons, however, that an anticipated implosion of agricultural markets might not occur, especially with respect to arrivals. Many creative ways to circumvent the ban surfaced in the weeks after demonetization. For example, our field visits revealed that in many mandis, old currency continued to be accepted for payment, at a discount, despite the ban. Across mandis, a sophisticated schedule of prices for produce had developed depending on whether one was trading in new or the old illegal currency. ${ }^{16}$ There were also reports that consequently those who had stashes of old currency, possibly black money, were buying up agricultural produce rather than deposit these in banks. ${ }^{17}$ Most often however, we found that goods were passing through but not money, so that farmers, agents and traders were transacting on credit. ${ }^{18}$ Sometimes multilateral

\footnotetext{
${ }^{14}$ In the current version of this paper, we do not explore this aspect.

${ }^{15}$ The World Bank, World Development Indicators, URL: https://data.worldbank.org/indicator/FB.CBK. BRCH. P5? end=2015\&start=2001, accessed on November 1, 2017

${ }^{16}$ See Krishnamurthy (2017), for example.

${ }^{17}$ Paddy mandi a green pasture for black money hoarders, The New Indian Express, November 22, 2016, URL: http://www.newindianexpress.com/states/tamil-nadu/2016/nov/22/ paddy-mandi-a-green-pasture-for-black-money-hoarders-1541249.html, last accessed on November 2, 2017.

${ }^{18}$ See for example, At Delhi's Azadpur Mandi, Lack of Money is Slowly Choking Business and Also Workers, The Wire, November 18, 2016, URL: https://thewire.in/81178/
} 
arrangements had evolved where farmer bought inputs for the impending agricultural sowing from family members of traders who they had just sold to on credit, thus settling the transaction in kind. In each of these cases, one would not expect to see a sharp impact on arrivals. In these cases, the impact of demonetization is likely on consumption and savings. ${ }^{19}$

Likewise if successive notifications easing restrictions on access to new currency were truly releasing constraints on cash, we would see a muted impact on average or a tapering off of negative impacts, if any. ${ }^{20}$ These also include innovative solutions by state governments. For example, in the southern state of Telangana, the government along with a bank issued coupons to trade in farmers' markets that could later be encashed. In Tamil Nadu, temples under the state government administration opened up their cash donation boxes for offerings made by pilgrims for exchange. ${ }^{21}$ All or any of these are factors that would mitigate the negative impacts of demonetization. We also believe that if itinerant small traders who pick up produce at the farmgate were themselves cash starved, we might actually witness trade that would have otherwise occurred locally within the village, make its way to the mandis, where perhaps the likelihood of finding a buyer is higher. In effect, the actual impact of demonetization on domestic agricultural trade is an empirical question.

azadpur-mandi-glimpse-agricultural-supply-chain-held-together-credit-goodwill-old-notes/, last accessed on November 2, 2017.

${ }^{19}$ Our fieldwork also indicated that the persons who were likely most affected were the farm workers and their families, who had not been paid wages since the farmer had no cash. For this group, remittances home had dried up and farm workers reported that they had cut back food consumption too to keep afloat. See: Jobless, these labourers can barely get one meal a day, The Economic Times, December 11, 2016, URL: http://economictimes.indiatimes.com/news/politics-and-nation/ jobless-these-labourers-can-barely-get-one-meal-a-day/articleshow/55920755.cms., last accessed on November 2, 2017.

${ }^{20} \mathrm{See}$ for example, the following reports, Demonetisation: Govt relaxes rules, allows farmers to use Rs 500 notes to buy seeds, Business Standard, November 21, 2016. URL: http://wap.business-standard.com/article/economy-policy/ demonetisation-in-a-partial-rollback-govt-allows-farmers-to-use-old-rs-500-notes-116112100378_ 1.html, last accessed on November 2, 2017 and Further demonetisation relaxation likely for farm sector, weddings, Business-Standard, November 23, 2016, URL: http://www.business-standard.com/article/economy-policy/ further-demonetisation-relaxation-likely-for-farm-sector-weddings-116112201345_1.html, last accessed on November 2, 2017.

${ }^{21}$ See for example, Temple donations in $T N$ see slump post demonetisation, The New Indian Express, November 19, 2016, URL: http://www.newindianexpress.com/states/tamil-nadu/2016/ nov/19/temple-donations-in-tn-see-slump-post-demonetisation-1540260.html, last accessed on November 2, 2017. and Telangana govt has a creative solution for farmers' market in demonetisation woes, The News Minute, November 19, 2016. URL: http://www.thenewsminute.com/article/ telangana-govt-has-creative-solution-farmers-market-demonetisation-woes-53135, last accessed on November 2, 2017. 


\section{Data and Empirical Strategy}

\subsection{Data}

For the analysis we focus on commodities chosen to represent each of about 12 commodity groups identified by the Ministry of Agriculture. ${ }^{22}$ The choice of these crops is based on the cultivated (gross/net) area under the group in the 2015 although we have taken care that these broadly reflect the shares over the period 2012-2017 (See Table 2) so that we are able to account for commodities that reflect Indian agriculture broadly. For foodgrains (i.e., cereals and pulses), the crops we consider account for $85 \%$ of land under foodgrain, for oilseeds, the proportion is $87 \%$ and for horticulture (fruits, vegetables, aromatic plants, plantation crops and spices), the commodities included account for close to $60 \%$ of the total area under such crops. ${ }^{23}$

Not all of these commodities are produced in all the states nor in all seasons. Our list of crops include kharif or monsoon crops, that were either being harvested or were ready for harvest at the time of demonetization. The typical kharif crop involves sowing in June and harvests ranging from October to January depending on the crop and the varieties. Our focus on kharif crops is because we expect that demonetization would mainly impact these and not those that are typically grown in other seasons. For example, the other important seasons are rabi (winter) and summer. Rabi sowing typically runs from November to February or March and summer between February and June. $^{24}$ We use crop year rather than calendar or financial years. Crop years run from July in each year to June the following year. We use data spanning the crop years 2012 to 2017. By crop year 2017, we mean the year that runs July 2016 through June 2017. Our choice of years is to ensure that the set of regulated markets are somewhat uniform. A longer time span would pick up variations in reporting, neglect newer markets and include markets that were either merged with others or ceased to function. In aggregate, we analyze 35 commodities spanned across commodity groups of cereals, pulses, oilseeds, spices, plantation, sugar, fibre. We include vegetables and fruits to examine the impact on perishable commodities.

For these selected crops, we analyze mandi arrivals across all regulated mandis in the country. These data are reported daily for each trading day. Arrivals typically refer to those lots for which official gate entry has been made. These data for arrivals cannot be construed as representing all trade for two reasons. In several states, reforms of the APMC Act allow direct transactions between farmer and retailer/processor/consumer. Crops such as sugarcane for example are delivered to sugarcane factories and increasingly crops such as cotton are delivered directly to ginning, pressing

\footnotetext{
${ }^{22}$ Commodities are grouped into cereals, pulses, oilseeds, fibres, sugar and beet, plantation crops, spices, fruits, vegetables, flowers, aromatic crops and honey. Livestock products are considered separate from "crops".

${ }^{23}$ It is difficult to get an estimate of the selected commodities' contribution to the value of production of all crops, without also selecting a set of prices that represent a normal year. We therefore preferred to use acreage.

${ }^{24}$ In this paper, the kharif crops include paddy, maize, jowar, ragi, soyabean, cotton and rabi crops include wheat, gram, groundnut, rapeseed and mustard. These were determined by arrival patterns as well as dominant season of production.
} 
units and mills, groundnut to decortication units and so on. These lots would not therefore pass through a mandi. Second, despite the mandate for commodities to be trading in these regulated markets, for a number of commodities in a number of locations, trade is known to occur outside the mandi, that often goes unrecorded in order to avoid payment of mandi fees and taxes. These caveats aside, nationally representative surveys of agricultural households suggest that the transactions involving direct sale to processors is fairly limited except for a few commodities.

We source our data from the Ministry of Agriculture, Government of India. In general, the data reported include daily arrivals and prices. These data are often made public after a lag and are updated over time. We downloaded these data at different points in time allowing for enough time for these data to be complete. We also conducted random checks at the time of analyzing to ensure that we were using the same data that were available on that data. ${ }^{25}$ Arrivals are typically recorded at the gate and do not necessarily imply a sale; they may be stored at the commission agent's premises until sale. We treat each unique mandi name as separate. Typically there are APMC markets and sub-yards or sub-markets and sometimes the parent APMC reports data collated from all its sub-mandis. We do not attempt to combine these ourselves and retain the original form in which data are available. Further, arrivals are reported at commodity level, so that it is impossible to identify which how much of each variety arrives. While arrivals are the total for each trading day at the mandi, three prices are reported - the minimum price at which a lot is traded, the maximum price as well as the modal transactions price. In our experience, the modal price is more a ballpark estimate than the actual mode. These prices are collected by mandi officials who physically circulate in the market multiple times during trading hours to record these in consultation with the agents and traders. In rare cases, it is recorded as the most frequently traded price based on the prices of each lot. In some markets it is recorded as a linear combination of maximum and minimum, and is mode only in name. In contrast to arrivals, prices are more often than not documented for different varieties separately, although in practice we found that the category "Others" was often chosen as the default even when the variety was clearly distinguishable. We use all data for the selected commodities. For prices we choose one variety per mandi, the one that appears first in the database and where variety is explicit, we control for variety in our regressions. ${ }^{26}$ We use the minimum prices since we feel that this systematically records the lowest price of the day, mainly since minimum prices are nearly always reported whereas this is not the case with modal and maximum price. Our analysis therefore tracks if the minimum prices at which produce was traded fell, which would be a more conservative approach to the analysis than to track maximum or modal prices. Our sense is that minimum prices are much more likely to hold up given that even during such a crisis, farmers must have a reservation price that has a

\footnotetext{
${ }^{25}$ We downloaded data at four points of time - end-November 2016, end-December 2016, mid-January 2017, midMarch 2017 and mid-August 2017.

${ }^{26}$ We are currently processing results to test the sensitivity of results to the inclusion of the entire range of prices for all varieties in a specific mandi.
} 
Figure 3 Marketing channels for kharif crops, 2012-3.

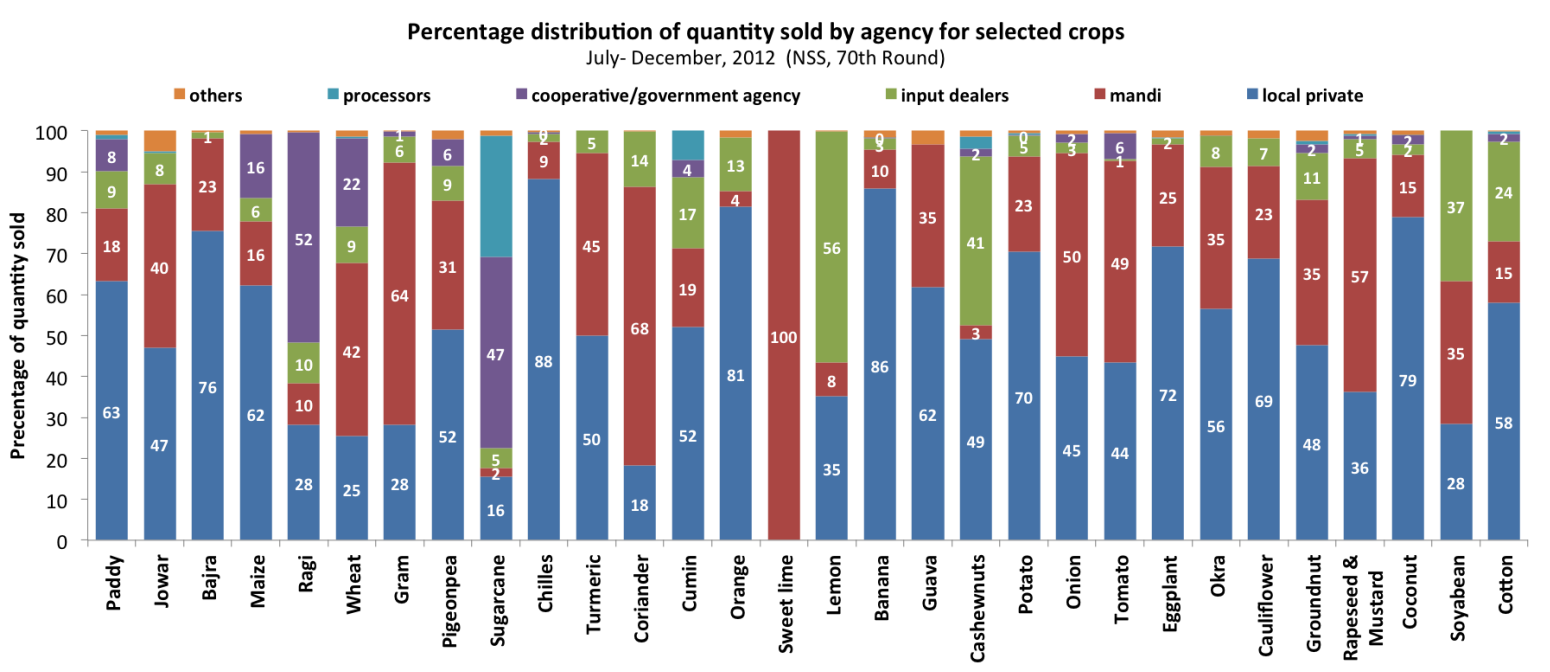

lower bound. Maximum and modal prices could possibly be more responsive to a cash crunch, if demand collapsed. Although we use trade valued at minimum prices and more generally minimum prices as the outcome of interest, we estimate these models also using maximum prices to check the sensitivity of our results. ${ }^{27}$

Table 2 presents percentage of arrivals during the kharif season for each selected commodity. Commodities such as paddy, maize, soyabean, cotton are primarily grown as kharif crops. The major rabi crops include wheat, cumin and Bengal gram. The table also indicates the average number of mandis that reported arrivals in a crop year during 2012-16. Cereals such as paddy, wheat, maize, bajra have a wide geographical coverage. Arrivals for soyabean, tur and Bengal gram is also reported by a large set of mandis. Within perishables, we see a large number of mandis reporting arrivals for onion, potato, tomato and brinjal. A smaller number of mandis report arrivals for the fruits analyzed in the study.

As discussed in Section 2, not all agricultural produce pass through mandis. Some of it is directly sold to co-operatives and government agency, mills and processors and to private traders through contracts. ${ }^{28}$.

Commodities such as wheat, maize, bajra (peal millet), tur (pigeonpea) and Bengal gram (chickpea) have a large share of production that is sold via mandis. Others such as ragi (finger

\footnotetext{
${ }^{27}$ Quality differentiation across lots even for the same variety is one reason for price variation but there is no reason to believe that quality would be systematically good or bad post-demonetization. This is unobserved and remains a limitation of the data used.

${ }^{28}$ The 70th Round of the National Sample Survey conducted in 2012-13 offers the best estimates of marketing channels for commodities that is nationally representative of agricultural households in India. Figure 3 shows the commodity wise share transacted via different channels by the farmer. It is worth noting that several trades that occur through private buyers who are typically itinerant vendors who visit the village pass through mandis where the produce is aggregated and sold onward.
} 
millet), jowar (sorghum), groundnut, soyabean have a much smaller share. ${ }^{29}$ Figure 4 presents weekly arrivals for six commodities analyzed in the sample. The shaded region in the graph indicates the kharif season, the period that was hit by demonetization (Week 18-19). For nonperishables, arrivals are uneven throughout the year. The peak season for paddy, soyabean and cotton is the kharif season. Arrivals for tur typically arrive between December to January. In contrast, arrivals for perishables such as tomato and banana are spread throughout the year.

\section{$3.2 \quad$ Empirical strategy}

To estimate the impact of demonetization, we rely on a difference-in-differences regression framework with the event of demonetization as the treatment. The crop year 2017, running from July 2016 to June 2017 represents or serves as the treated unit (the year when demonetization occurred) and the other years represent control or comparison units, so that we have one treated year and comparison years. We then use the days before (after) November 8 in each year as the pre(post)treatment variable - the treatment referring to the event of demonetization. We therefore apply the difference-in-difference to time-space rather than the customary state-space framework. ${ }^{30}$

We analyze the impact on total value (computed as the product of the minimum price and arrivals) at a mandi for each commodity on a day using the following regression equation:

$$
\ln V_{c, m, t}=\alpha_{0}+\alpha_{1} D_{\text {post }-N o v 8, t}+\alpha_{2} D_{2016, t}+\alpha_{3} D_{\text {post }-N o v 8, t} \times D_{2016, t}+\beta_{4} X_{m, t}+\epsilon_{c, m, t}
$$

where $\ln V_{c, m, t}$ represents logarithm of daily value of arrivals for commodity, ' $c$ ', traded in mandi, ' $m$ ', on date, $t$. $\alpha_{1}$ measures the difference on average between post-November 8 arrivals value relative to pre-November 8 arrivals value. This controls for the trend in arrivals value over the season, which ensures that the impact of demonetization is not contaminated by an underlying intra-season trend in arrivals. Most kharif crops exhibit intra-seasonal differences increasing over the season and tapering off (as discussed in the context of Figure 4). The coefficient $\alpha_{2}$ measures the average daily arrivals value for 2016-17 relative to other years. If for example, the year 2016-17 saw a bumper harvest or a greater area was devoted to a particular crop, translating into greater production and hence larger arrivals, one would expect arrivals (and thus their value) to be higher on average than in previous years. This is especially important in the context of demonetization

\footnotetext{
${ }^{29}$ As mentioned earlier, soyabean and groundnut are often bought by processors. Ragi and jowar typically grown by poorer farmers and are sold within the village.

${ }^{30}$ We prefer this innovation to using a predictive model because we believe the predicted values are associated with large errors. For example Banerjee and Kala (2017) are able to predict $77 \%$ of values with their model and they state it varies widely across mandis. A related issue is that predicted values using rain might be irrelevant for irrigated agriculture. Likewise, the predictions of arrivals, even in rainfed areas, may depend more on the timing of onset of the monsoon and this could vary from year to year. Further, produce often travels long distances and across multiple states. In these instances, rainfall in the district where the mandi is located has limited bearing on arrivals; rainfall in the production sheds are more likely to matter.
} 
Figure 4 Weekly arrivals for sample commodities

The graphs below show weekly arrivals for six commodities belonging to each commodity group for three crop years analyzed in the study. Weekly arrivals are computed as sum total of arrivals for a commodity in a week across all mandis within a crop year. Week 18-19 represent the week in which demonetization was announced in 2016-17. The shaded region represents the Kharif season which spans from October to January. The x-axis shows the corresponding week in a crop year.
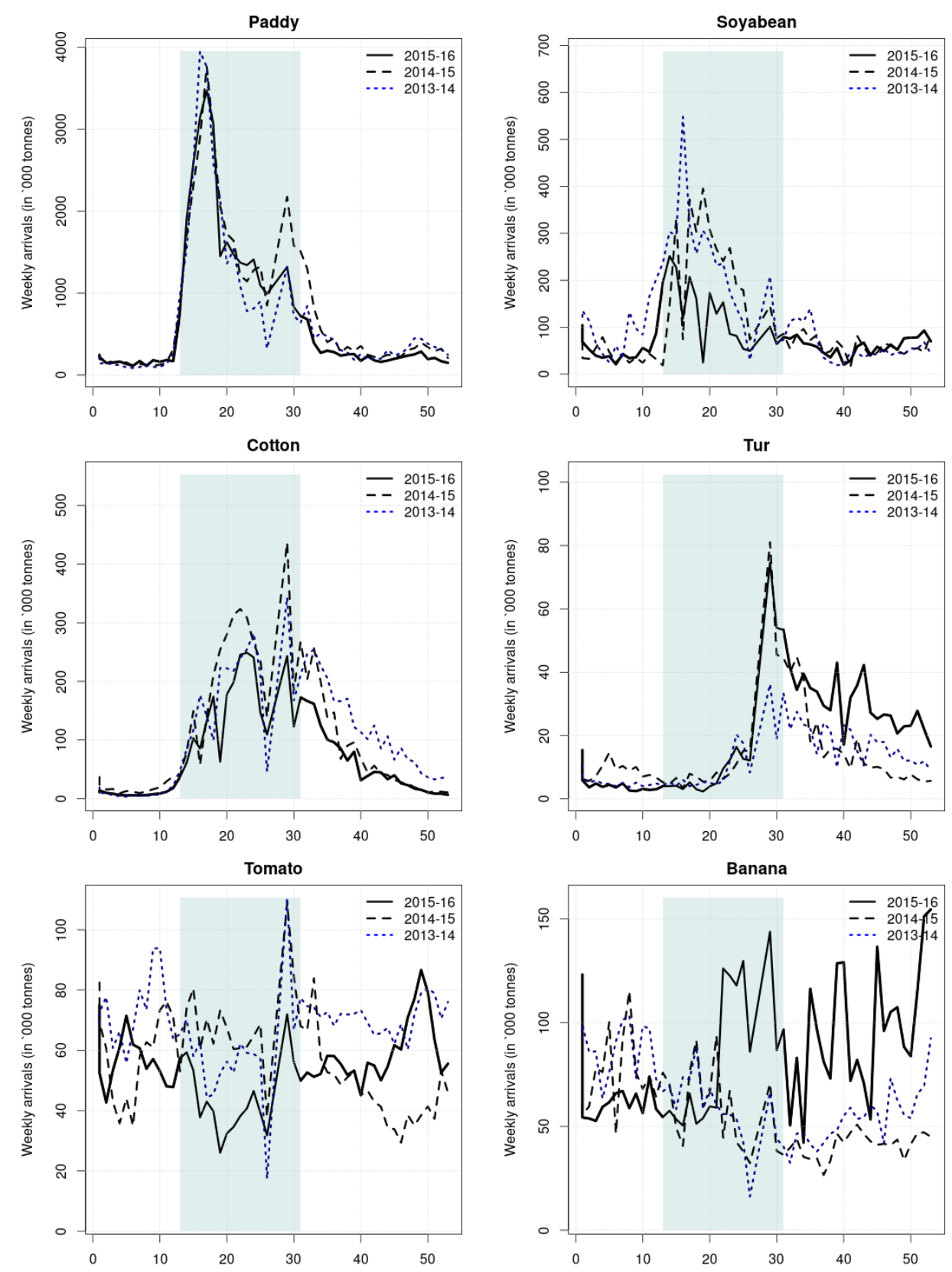
since 2016-17 coincided with a good agricultural season in terms of adequate rains, leading to bumper harvests for many commodities. Many observers have commented that the price declines observed could well be due to the high supply this year. Further, estimates of production this year relative to earlier years for selected crops suggests that it is in fact true for at least a few key commodities (Table 1). $X$ 's indicate control variables discussed later in this section.

We estimate variants of this model, pooling all the commodities to estimate the overall impact on aggregate for the 35 commodities. The estimates from this model gives the best proxy for value of trade displaced (or reduced) domestically in the mandis and is therefore central to our analysis.

Next, we decompose the impact of demonetization into impact on prices and impact on arrivals. As discussed in Section 2.1, the net impact on traded value could be driven by price effect or arrivals effect or both. To anaylze the impact on arrivals, we estimate the following regression equation:

$$
\ln Y_{c, m, t}=\beta_{0}+\beta_{1} D_{\text {post-Nov8,t }}+\beta_{2} D_{2016, t}+\beta_{3} D_{\text {post }-N o v 8, t} \times D_{2016, t}+\beta_{4} X_{c, m, t}+\epsilon_{c, m, t}
$$

where $Y_{c, m, t}$ denotes the logarithmic values daily arrivals in tons for commodity, ' $c$ ', mandi ' $m$ ', and date, ' $t$ '. Similarly, to analyze the impact on prices $\left(\ln P_{c}, m, t\right)$, we estimate the following regression:

$$
\ln P_{c, m, t}=\gamma_{0}+\gamma_{1} D_{\text {post }-N o v 8, t}+\gamma_{2} D_{2016, t}+\gamma_{3} D_{\text {post }-N o v 8, t}+\gamma_{4} Y_{c, m, t}+\beta_{4} X_{c, m, t}+\eta_{c, m, t}
$$

Since prices vary based on arrivals of a commodity, we include logarithmic values of arrivals $\left(Y_{c, m, t}\right)$ in the specification for prices (Model 3).

In the above models, $\alpha_{3}, \beta_{3}$ and $\gamma_{3}$ capture the average impact of demonetization on value of trade, arrivals, and prices in percentage terms.

We use mandi fixed effects to remove the time invariant characteristics of mandis, but use data of all mandis, however small or incomplete, to ensure that we subsume any trade diversion effects of the cash crunch. Agricultural policy in India is a state subject, and several ongoing market reform initiatives could influence agricultural marketing transactions. We thus include interactions between year and states as controls in part to account for these differential trends in all our pooled regressions. These state- year interactions would also pick up variations in production patterns across states and years.

With daily arrivals data, we control for day of the week effects, to account for mandi holidays and trade diversion effects between mandis since different mandis might have different holidays. Our preferred model includes data for the full year notwithstanding the fact that the crops may grow only in a particular season and most of it is marketed within a span of 3-4 months. We use dummy variables for each month to capture the variations in arrivals across months. Month and 
day effects also take care of variation in number of mandis reporting the data. We include variety effects to capture the differences in varieties. For all models, we trim $0.5 \%$ of the data; we correct standard errors for heteroscedasticity. ${ }^{31}$

In addition, we include a dummy variable to capture the Diwali effect in our analysis. Diwali is an important festival celebrated across India. The date of the festival, determined based on the traditional lunar calendar, falls in the month of October or November and varies from year to year. To the extent that in the period of our analysis, it straddles pre and post-demonetization dates (November 8 ) in different years. This could confound the identification of our estimates. The dates for Diwali during the period of our analysis are provided in Table 3. As can be seen from the table, the some dates are very close to the date on which demonetization was announced, especially for some years such as 2015-16. Our analysis of mandi trading patterns around Diwali indicates that arrivals start falling three days prior Diwali, and pick up after three days of Diwali (see Figure 5). Thus, we control for this effect by including a Diwali dummy which takes value one for the period of three days pre and post Diwali, zero otherwise. Most other key festivals fall before November 8 each year and are therefore not confounders.

Finally, we control for rainfall in all our regression specifications. Rainfall is captured at a monthly frequency at district level. We map all mandis studied here to their corresponding districts. We compute rainfall deficit or surplus as the difference between rainfall in a particular month and its historical average in that month over the past ten years. This is used as raw surplus or deficit. We also re-estimate the regression model by normalizing the difference the standard deviation of the historical rainfall data for that month. We call these as 'surplus (deficit)' and 'normalized surplus (deficit)'. We use two separate variables to capture the effect of surplus or deficient rainfall. We include twelve lags of rainfall data in the specification, to capture the entire cropping season that might potentially affect production, yield and marketed surplus. There is also the important issue of variations in sowing and harvest dates that typically respond to the arrival of rainfall at the time of sowing. Controlling for lagged rainfall measures of varying lengths accounts for these differences.

We implement the analysis using varying windows around demonetization in order to understand whether the impacts are transient or not and to analyze the strength of the impact of demonetization over time. The variation is likely to arise because of two key factors, as mentioned earlier. First, the government took several measures to ease the difficulties farmers were facing as the money began to be replenished (as shown in Figure 1 and Appendix C). These involved setting higher withdrawal limits for farmers and traders and enabling cooperative banks in rural areas to transact, among other things. Second, it is possible that farmers have limited storage capacity and were only able to hold out for a short time after which they would bring it to mandis for sale even if the prices

\footnotetext{
${ }^{31}$ In current work, we are examining the issue of serial correlation and correcting for these as well; our expectation however is that the results won't change substantially.
} 
Figure 5 Diwali analysis for a few sample commodities

The graphs below show event-study analysis 15 days pre and post Diwali. The bold blue line indicates the mean of arrivals during 2011-12 to 2015-16. The upper dashed blue line indicates the maximum arrivals in any of the years around Diwali, while the lower dashed line indicates the minimum arrivals. The black dashed vertical line indicates the Diwali day. The x-axis shows days spanning 15 days before Diwali to 15 days post Diwali. We exclude the crop year 2016-17 from this analysis.
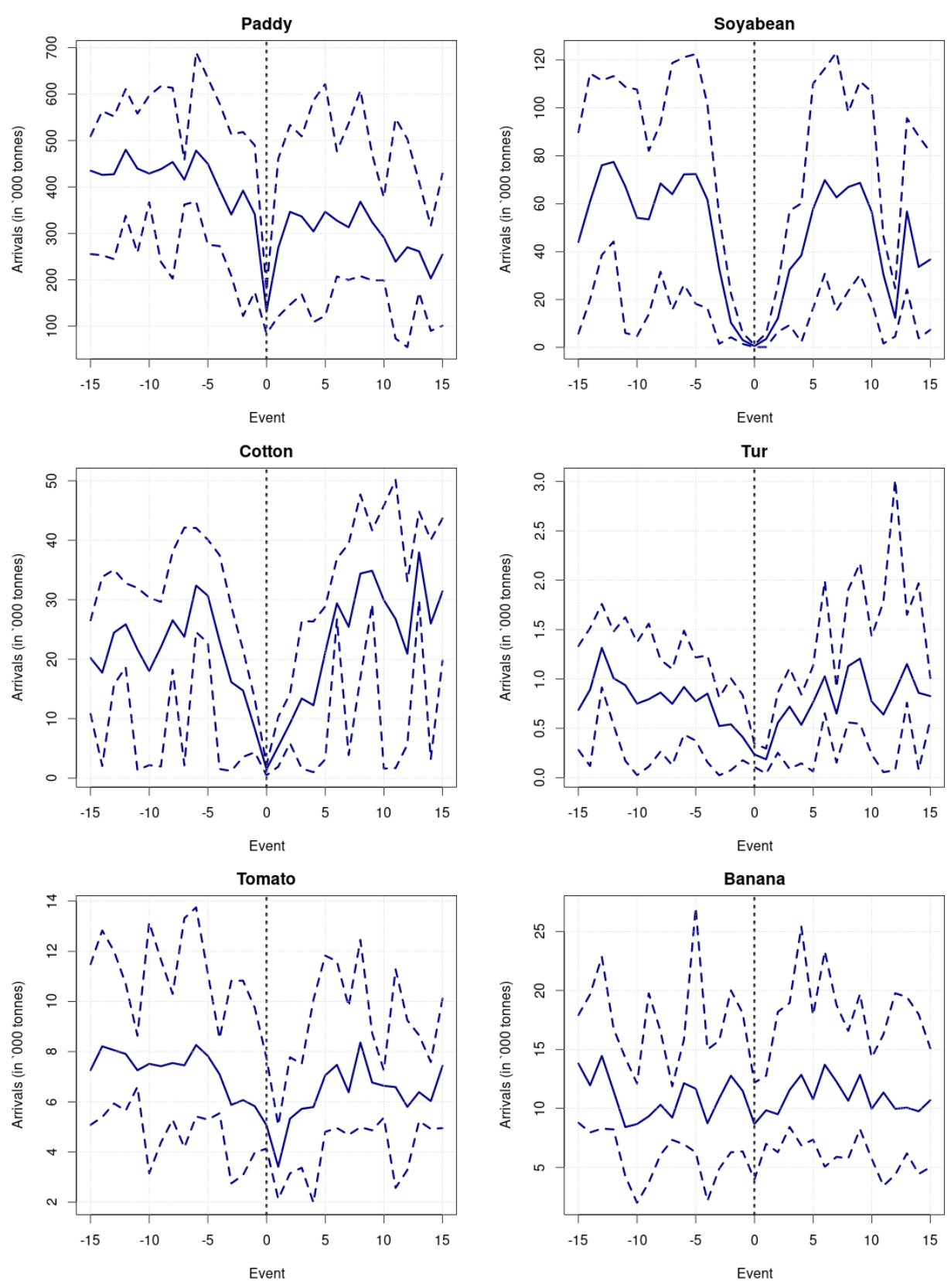
were low and their own circumstances challenging. We estimate the model for different windows around the even, starting with a comparison of one day after to 90 days after in most cases.

The identification strategy in this study is predicated on the assumption of parallel trends, that, in the absence of treatment the treated unit and control units would have shared a similar trend. We check this by plotting mean pattern of cumulated arrivals for control years vis-a-vis the pattern in the treatment year. Figure 6 shows the graph for some of the sample commodities. We see that the arrivals follow a similar trend across years, for the pre-November 8 period. Since the difference in differences approach only accounts for time-invariant unobservable characteristics that are systematically different across 2016-17 and comparison years, if there were idiosyncratic differences between these that result in different value of trends pre-November 8 , this would lead to biased estimates of impacts. For example, variations as observed in the case of cotton could be attributed to differences in production of the crop in an year and also possibly state level procurement. In order to account for these, we control for these fluctuations in production by using rainfall data.

We also check for any unusual dips or spikes prior to demonetization. We believe that this is largely irrelevant because the announcement of withdrawal of currency came as a surprise and was announced at 8 p.m. with currency remaining legal tender until midnight that day. ${ }^{32}$ Given that this is not a window for business in agricultural markets it is unlikely that there was transaction activity in anticipation of the change. Our graphical analysis support this.

We estimate the above set of models and begin our analysis with the impact on total value of trade. We then explore the nature of these impacts across kharif and rabi crops, perishables and non perishables, considering our hypotheses that these could be different across commodity groups or type. We then uncover patterns of impacts vis-a-vis total value and examine whether these come from impact on arrivals and via impact on prices using commodity by commodity regressions.

\section{Results}

\subsection{Impact on trade valued at minimum prices}

Our main results focus on difference in differences estimates from Model 1. We use the logarithm of value of arrivals for each mandi, by commodity, each day. We estimate this for each of the 90 days following the date of demonetization. Apart from the variables detailed in Model 1, where we pool all commodities, we use commodity dummy variables to capture commodity specific effects. We also use mandi fixed effects. ${ }^{33}$ Figure 7 shows the average treatment effects with successive windows.

\footnotetext{
${ }^{32}$ As a coarse verification that this was indeed a surprise, we graph the trend in google search in English based on two ways of spelling (Figure 2 earlier).

${ }^{33}$ We run several variants of these, for example without commodity effects. We also run alternate estimates that use variety effects too and then finally estimates that aggregates (over commodities) the total value of trade per mandi per day. These results are available with the authors and show stronger negative impacts of demonetization.
} 
Figure 6 Cumulated arrivals for a few sample commodities for control years and treated year

The graphs below show the cumulated arrivals within an year for the control years and the treatment year. We report the mean value of the cumulated arrivals for the control years.
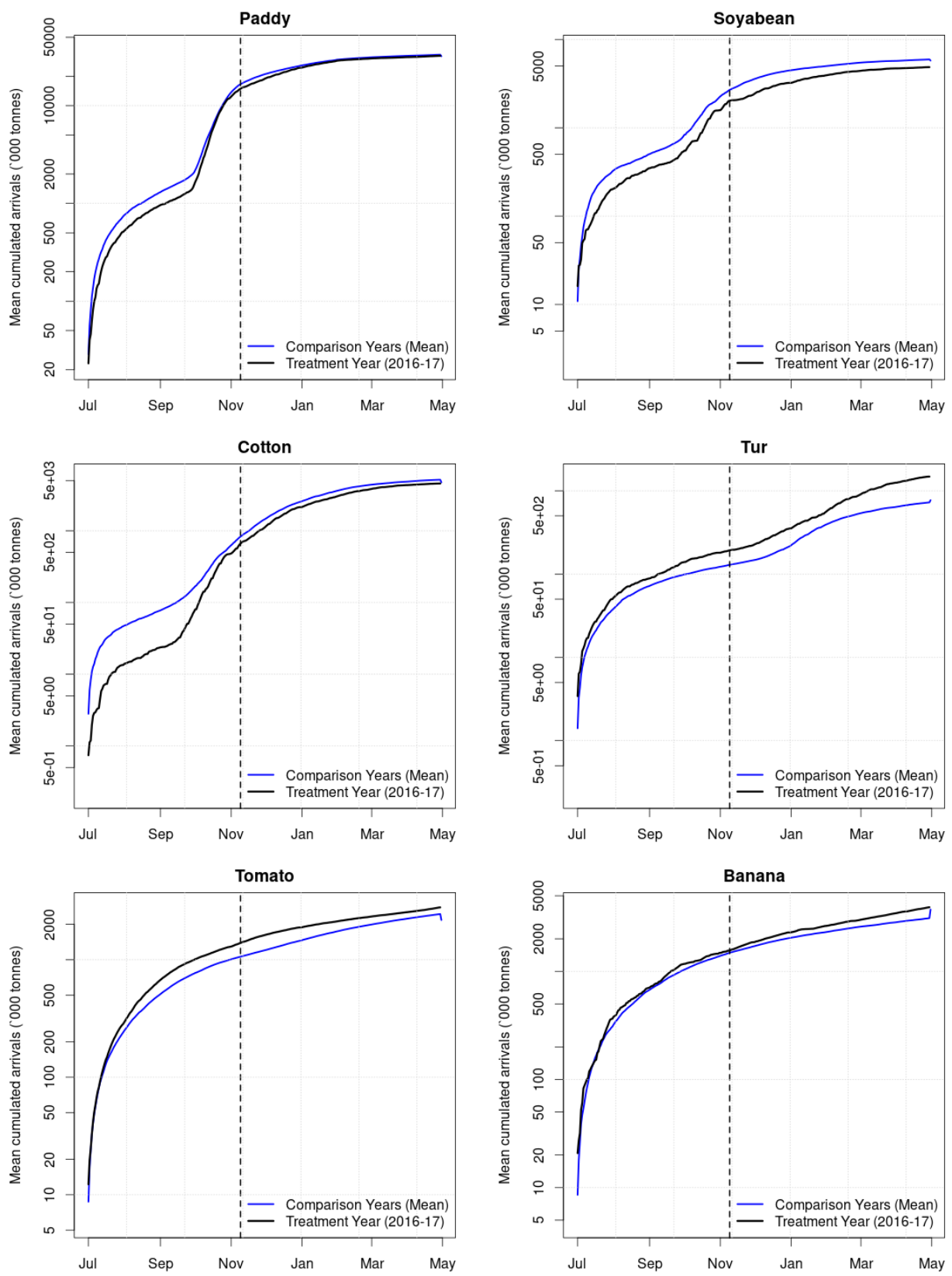
Figure 7 Impact on mean daily value of trade: Difference-in-differences Estimates

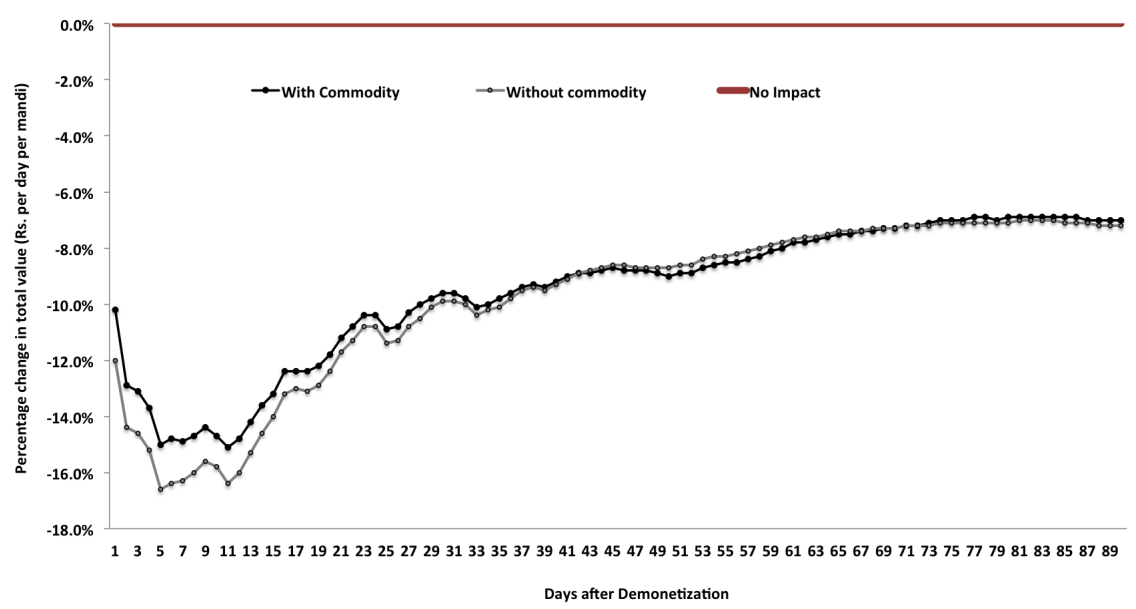

Source: Computed by authors.

The worst impacts occurred within a fortnight of demonetization with a trade displacement effect of around $15-17 \%$ at its worst. Thereafter, we observe a steady revival, which plateaus after a couple of days months suggesting reluctant recovery if not altogether stalling after the 75 day mark. By the end of 90 days after demonetization, mandis were seeing a loss of value of trade to the extent of 7 to $7.2 \%$ per mandi per day. ${ }^{34}$ We find that All of these results are statistically significant at $1 \%$. The apparent displacement of domestic agricultural trade in value terms could come from a decline in arrivals or a collapse in prices or most likely a combination of both. The next sections assess the relative strength of these effects.

\subsubsection{Heterogeneity of impacts}

How do these impacts vary across different categories such as perishable and non perishables, kharif and rabi crops? ${ }^{35}$ As outlined in the conceptual framework (Section 2.1), we anticipate that kharif crops would likely be more affected than rabi crops. We had also hypothesized that perishables could see steady arrivals but perhaps depressed prices, while for non-perishables, which farmers can store and hold out for better prices, the opposite may be true.

We estimate separate regressions for sub-groups of these commodities pooled together. The classification of crops into kharif and rabi was discussed earlier - the two are designed to be mutually exclusive but do not exhaust the commodities selected. In contrast we designated as perishables the

\footnotetext{
${ }^{34}$ In some models this is high as $13 \%$, not presented here. We estimated this model using maximum prices for selected days and the impacts were around 15-18\% with end-of-90-days results being comparable to the results with minimum value.

${ }^{35}$ The distributional consequences of demonetization are somewhat more challenging to uncover and we continue to work on identifying those mandis which may have been worse affected than others based on their location, access to banks, commodities they may grow and so on.
} 
following commodities : apple, banana, okra, eggplant, cabbage, cauliflower, guava, lemon, lime, mausambi, orange and tomato. All others are deemed non-perishables. ${ }^{36}$

Table 4 provides the average treatment effects across categories. We find that the mean trade value collapse was much sharper among the perishables than the non-perishables. The perishables saw a decline in trade to the extent of $22 \%$ per mandi per day in the month following demonetization. It recovered slightly after the first month, but even by the $90^{\text {th }}$ day, trade in perishables had declined by over $18 \%$ per mandi per day over three months. The impact on non perishables was lower. The maximum decline in non perishables was observed in the week following demonetization when trade declined by $11 \%$ per mandi per day over the week. It recovered after that, and by the end of the $90^{\text {th }}$ day, the decline was close to $1.3 \%$ per mandi per day over the three months period.

The most likely reason for this variation in impacts is due to demand and supply forces. While in the case of perishables, only the demand may have shrunk, depressing only the prices, in the case of non perishables, it is likely that both demand and supply was shrunk. These impacts will be visible in the prices and arrivals analysis, which we discuss in next section. that

The impacts on kharif and rabi also vary across the two categories and over time. ${ }^{37}$ We find that in the week immediately after demonetization, both kharif and rabi crops experienced a decline in trade, with kharif losing $5 \%$ per mandi per day, while rabi losing $15 \%$ per mandi per day in the seven day period. However, in the subsequent weeks, we find that trade value instead increased across both these categories, with the impact on kharif stronger than rabi crops. Reasons discussed in Section 2.1 such as the use of innovative techniques to dispose off old notes or higher procurement by the government could be at play for the observed increase.

We also see significant variation in the impacts across commodities. Based on individual commodity regressions on value of trade (reported in Table 8)), we find that the commodities that were hit the hardest in the immediate aftermath of demonetization were soyabean and coriander seed. ${ }^{38}$ Soyabean trade fell by $69 \%$ per mandi per day over the seven day period following demonetization. Coriander seed, on the other hand, saw a decline in trade to the extent of $82 \%$ over the same period. Both these commodities started showing signs of recovery over the course of 30 days following demonetization. We also see that commodities such as paddy and cotton saw a positive impact on trade even in the week immediately after the event of demonetization.

In all, the findings are broadly consistent with anticipated outcomes and have an intuitive interpretation. In the next section, we examine the source of variation in these impacts in the form of arrivals and prices.

\footnotetext{
${ }^{36}$ Arguably, this classification is not the only way to do this and it can be argued that some of those in list of perishables are not quite as perishable as others, or vice versa. Our contention is that small changes in these categories do not make a large difference, given that the purpose is to elicit patterns of impacts.

${ }^{37}$ The kharif results presumably capture mostly sale from current production, while the kharif results would likely represent sales from mainly stored crops from past harvests.

${ }^{38}$ We re-estimate these regressions using maximum value of trade computed as the product of maximum prices and arrivals. Our findings remain the same.
} 


\subsection{Sources of impacts}

Just as we examined the heterogeneity of impacts on trade across commodity groups, we now identify whether the impacts we see on value are generated by declines in arrivals and/or prices. Further given the unique nature of each crop, we analyze each of the 35 crops independently. We present a few below for illustrative purposes with the rest of the results and the full results available with the authors.

Table 5 shows the impact on arrivals in the regulated mandis after the note ban of Nov 8, 2016. As hypothesized, we find that the arrivals fell in the week after the note ban, across almost all non perishable commodities except cotton seed. The decline in arrivals for perishable commodities is much lower than the non perishable commodities. ${ }^{39}$ Apple, which has a relatively longer shelf-life than the other perishables analyzed in the study, also saw a significant decline in arrivals in the week post demonetization. The table also reports change in arrivals two weeks after demonetization relative to the week prior the event. While it appears that the decline in a few commodities such as maize, rice, arhar, cashewnuts recovered slightly, several other commodities continued to see a sharp fall. To put these numbers in perspective, we also examine the mean week-on-week changes in arrivals for the control years as well. Except for paddy and raw turmeric, we do not see such a sharp decline in the remaining years. The last column in the table also shows the proportion of arrivals that come during the kharif season. The table shows that the impact of the event was not only restricted to kharif crops such as maize and soyabean but was also observed on rabi crops such as wheat and Bengal gram.

Nevertheless, the weekly changes do not capture the possible effects of other factors such as rainfall, variation in production and so on. Thus, we next evaluate the impact of the event using the difference-in-difference regression specification described in Section 3.2. We estimate the regression using varying window sizes from 1 to 60 (along with 75 and 90 separately) days after demonetization. This covers three months of period when there was an economy-wide severe shortage of cash. In the following subsections, we discuss the results for arrivals and prices separately.

\subsubsection{Impact on arrivals}

We present the $\beta_{3}$ coefficient estimates based on Model 2 from the regression on arrivals for select few commodities in Figure 8.

The $\beta_{3}$ coefficient for paddy turns out to be positive and significant, indicating that there was in fact a positive impact on arrivals after demonetization. This indicates that the increase in traded value that we saw in the previous section was driven by higher arrivals. A possible reason for this could be that bulk of paddy procurement is done by various state agencies such as the Food

\footnotetext{
${ }^{39}$ It is likely that perishables saw a significant decline in prices relatively to the week before demonetization. We analyze this in the section on "Impact on prices".
} 
Figure $\mathbf{8} \beta_{3}$ for estimated regression for post event window from one to ninety days after demonetization

The graph shows the $\beta_{3}$ coefficient estimate of the regression:

$$
\ln Y_{c, m, t}=\beta_{0}+\beta_{1} D_{\text {post }-N o v 8, t}+\beta_{2} D_{2016, t}+\beta_{3} D_{\text {post }-N o v 8, t} \times D_{2016, t}+\beta_{4} X_{c, m, t}+\epsilon_{c, m, t}
$$

where ' $\mathrm{Y}$ ' denotes arrivals, 'c' as commodity, ' $\mathrm{m}$ ' as mandi and ' $\mathrm{t}$ ' as date. $\beta_{3}$ is the coefficient of interest, which captures the percentage change in arrivals as a result of demonetization. The regression equation also includes control variables such as lags of rainfall data, and Diwali effect. Mandi, month, day of the week and variety effects are also included. Red dots indicate significant coefficients at $5 \%$ level, while blue dots indicate insignificant coefficients. Standard errors are robust to heteroscedasticity. The x-axis shows the post demonetization window size used in the estimation.
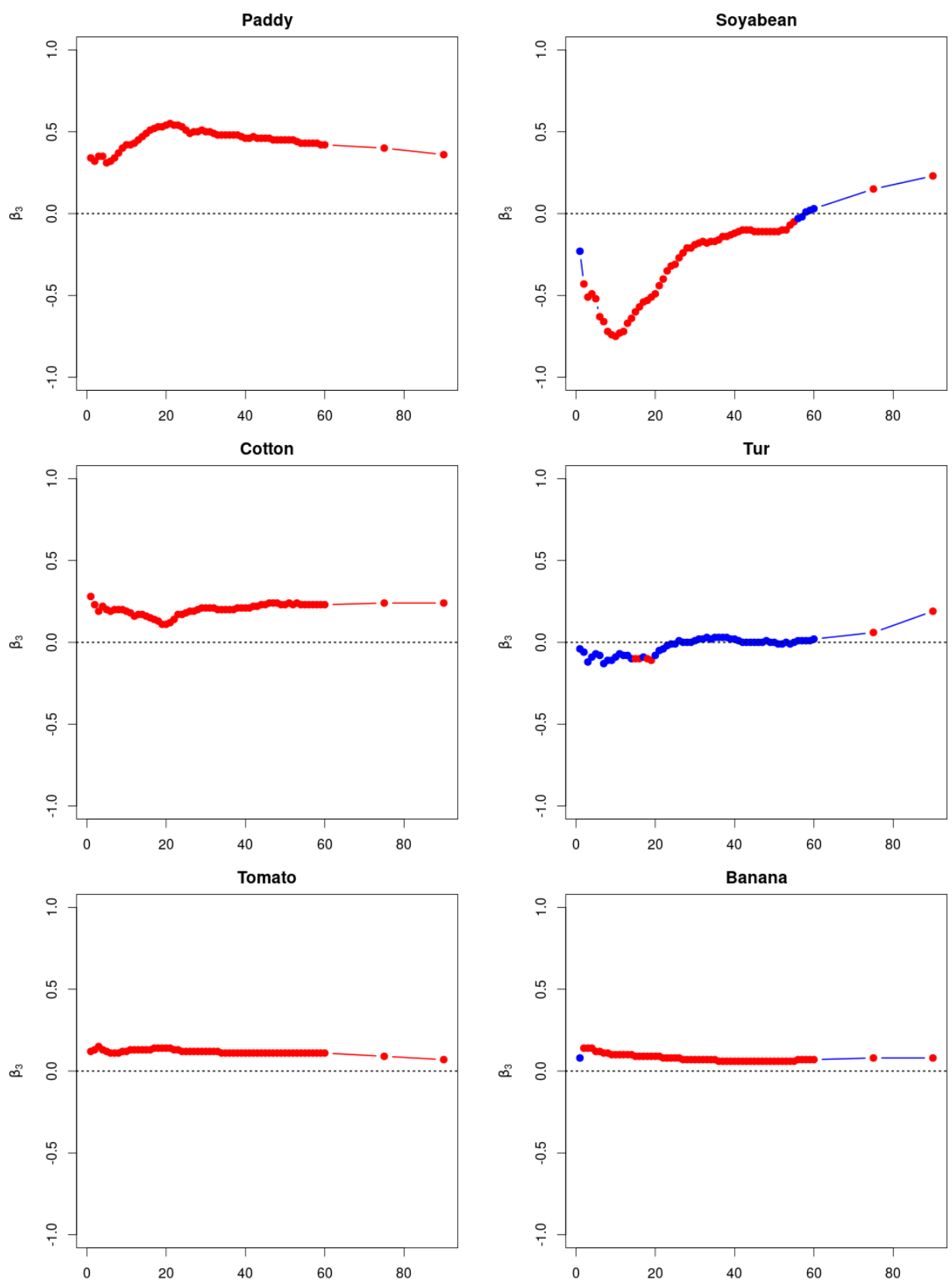
Corporation of India (FCI) and other state level Civil Supplies Corporations. ${ }^{40}$ Payment for these procurements is, in most cases, made directly to the bank account of the farmer, with the exception of two states, where it is first transferred to the bank accounts of commission agents, who then transfer it to farmers' bank accounts. Government reports suggest that this procurement for the season 2016-17 as of February 28, 2017 was 8.27\% higher than the previous year (Government of India, 2016a).

The coefficient for soyabean, in contrast, turns out to be negative and significant. The graph indicates that initially, there was a severe impact of demonetization on soyabean, with the arrivals falling by as much as $60 \%$ by day 10 . However, the situation improved after a few days, with the beta coefficient getting close to zero around day 27 , and eventually positive. The positive coefficient shows that the arrivals which were earlier not sold in mandi were now making their way to these markets. Thus, the impact was observed until one month after demonetization. The third graph shows the impact on arrivals for cotton. Cotton is typically sold to ginning units and spinning mills via private traders with only an estimated $15 \%$ traded in mandis (Figure 3). This is perhaps why we see negligible impact of demonetization on cotton arrivals. Within the pulses category, we see that the tur saw a significant negative decline. The arrivals for tur fell by as much as $30 \%$ in two weeks after demonetization. The arrivals after two weeks see some recovery, with the size of the $\beta_{3}$ coefficient reducing to 10 percent.

We now turn to perishable commodities show in the graph, tomato and banana. As expected, we do not see a decline in arrivals of these commodities. Instead, we see a positive and significant impact on arrivals. This suggests that demonetization actually spurred an increase in arrivals. Both these commodities rely heavily on private traders ( $44 \%$ and $86 \%$ ) who buy produce at the farm gate or within the village (Figure 3). One plausible explanation is that the private traders, being cash strapped themselves, do not show up so that the farmers now divert produce to the mandi. A plausible explanation is therefore that for commodities that rely on private traders and are perishable, demonetization actually crowded in trade into the mandis.

Given that demonetization took place when the monsoon crop was either being harvested or had just been harvested it is unlikely that the winter crops were affected. Trade in rabi commodities typically are during the months of February-April and given that storage is not widely prevalent, one would not expect the volumes of arrivals to alter dramatically during the period after demonetization. Yet, the effect for some rabi crops seem significant.

\footnotetext{
${ }^{40}$ As much as $30 \%$ of annual production of rice is procured by the Government and much of this is procured during November to February. While some of it is procured in the form of rice from millers, a significant share is bought as paddy and custom milled by the government.
} 


\subsubsection{Impact on prices}

We now examine the impact on prices by estimating commodity specific regressions described in Model 3. Figure 9 presents $\gamma_{3}$ coefficient estimates for the same set of commodities presented in Section 4.2.1.

We see that the coefficient, $\gamma_{3}$ is negative and statistically significant in the period after demonetization for paddy and soyabean, indicating a fall in prices in the range of $2-7 \%$ as a result of the event. Both these commodities are major kharif and non perishable crops, where farmers have the choice to store. Paddy and cotton, as discussed in Section 4.2.1, are procured by the state or by processing units, hence the payments for these commodities is made via cheques. In addition, higher purchase of paddy by traders to dispose old currency could have kept the demand high, and saved the prices from a huge decline. Prices of tur, as was observed in the case of arrivals, fell much more sharply (10-50\%). A possible reason for the observed sharp fall in both prices and arrivals of tur could be attributed to the bumper crop that was observed in 2016-17.41

Tomato, a perishable, saw a significant decline in prices. Prices fell to as much as $50 \%$ in the period immediately after demonetization. The same was true for banana, the prices of which fell by $11 \%$, only to recover to $9 \%$ by the end of 90 days.

A summary of all commodity specific regression results for various windows $(7,15,21,30,60$, 75 and 90 days) is presented in the Appendix Tables 8-14, with specific focus on the treatment effect coefficients, $\alpha_{3}, \beta_{3}$ and $\gamma_{3}$.

\section{$5 \quad$ Robustness checks and caveats}

The difference-in-differences technique presumes that in the absence of demonetization, the patterns or trends in arrivals and prices in 2016-17 kharif would have been comparable to that in previous years, even if in actual volumes or prices they are not. We controlled for monthly seasonality, day of the week effects and rainfall to ensure that the differences across years in observable characteristics were accounted for. We also implemented regressions with state year interactions that accounted for differential agricultural marketing policy changes in different states. However, there could still be systematic unobservable factors that confound our identification of the causal impact of demonetization. In order to strengthen the causal interpretation of our analyzes, we undertake a series of robustness checks and falsification tests.

For the impact on total value of agricultural trade we use a Synthetic Control approach (Abadie et al., 2010; Abadie and Gardeazabal, 2003; Abadie et al., 2014) to validate the findings of the difference in differences approach but also to conduct placebos to ensure the impacts we attribute

\footnotetext{
${ }^{41}$ See As prices head south, tur dal farmers seek centre's support, Business Line, Decmeber 6, 2016. URL: http:// ww. thehindubusinessline.com/economy/agri-business/economy/article9414035.ece, and Commodity profiles for Pulses, March 2017, URL: http://agricoop.nic.in/sites/default/files/Pulses.pdf
} 
Figure $\mathbf{9} \gamma_{3}$ for estimated regression for post event window from one to ninety days after demonetization

The graph shows the $\gamma_{3}$ coefficient estimate from the regression on prices for individual commodities. The regression equation is specified below:

$$
\ln P_{c, m, t}=\gamma_{0}+\gamma_{1} D_{\text {post }-N o v 8, t}+\gamma_{2} D_{2016, t}+\gamma_{3} D_{\text {post }-N o v 8, t}+\gamma_{4} Y_{c, m, t}+\beta_{4} X_{c, m, t}+\eta_{c, m, t}
$$

where ' $\mathrm{P}$ ' denotes prices, ' $\mathrm{c}$ ' as commodity, ' $\mathrm{m}$ ' as mandi and ' $\mathrm{t}$ ' as date. $\gamma_{3}$ is the coefficient of interest, which captures the percentage change in prices as a result of demonetization. The regression equation also includes control variables such as lags of rainfall data, and Diwali effect. In addition, it also controls for arrivals. Mandi, month, day of the week and variety effects are also included. Red dots indicate significant coefficients at $5 \%$ level, while blue dots indicate insignificant coefficients. Standard errors are robust to heteroscedasticity. The x-axis shows the post demonetization window size used in the estimation.
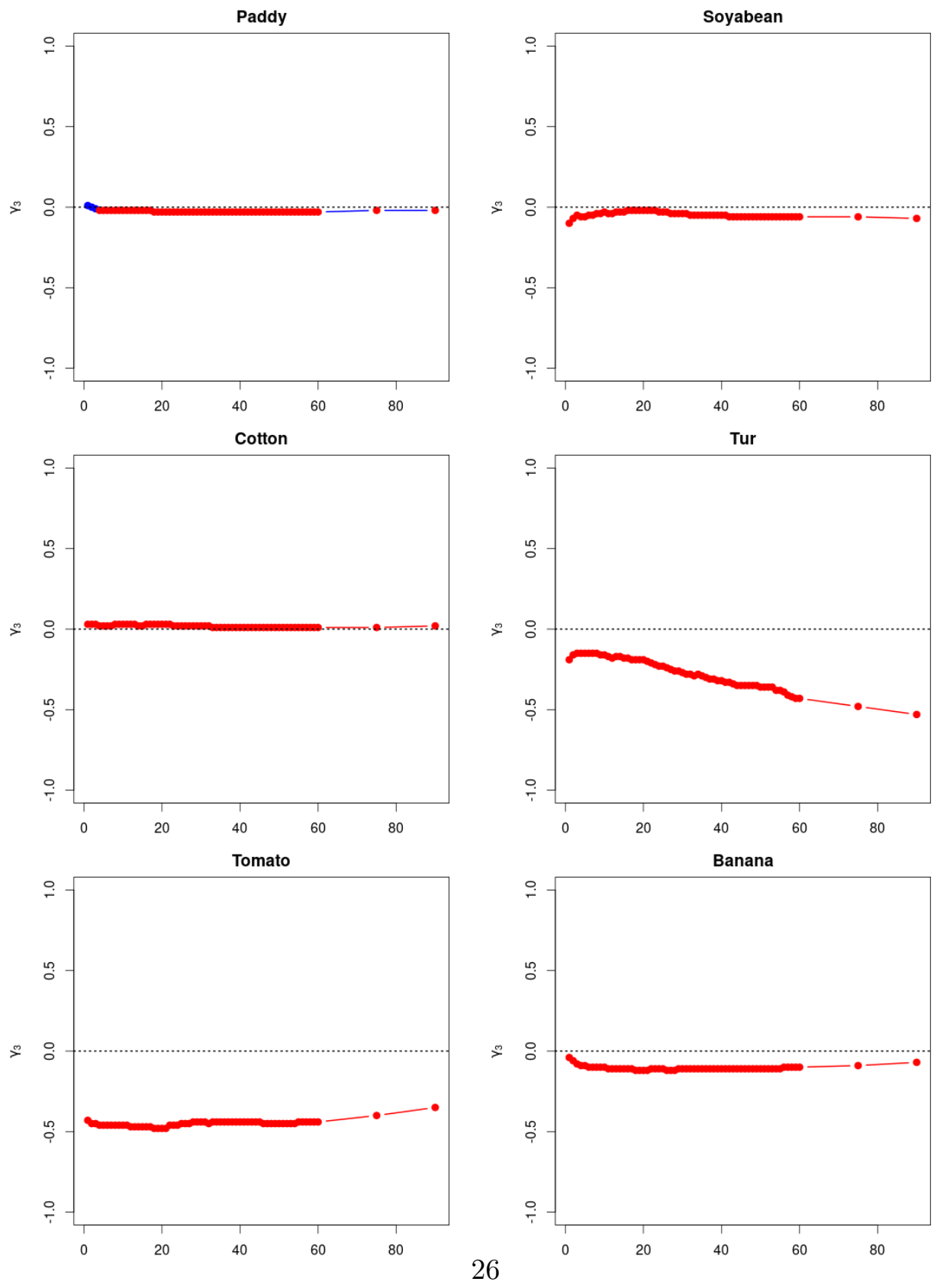
to demonetization are in fact justified. The findings from the synthetic control approach offers confirmation of our findings. These are described in detail in Appendix A.

As part of the falsification tests, we pick data for commodities one would not expect to be impacted by demonetization. As mentioned not all trade occurs through mandis nor are all transactions based on cash. If the withdrawal of notes only impinges on cash transactions, we would not expect it to impact those commodities that already have contract based electronic payment based transactions. Another aspect that likely will not get affected is international trade where most trade occurs based on prior contracts and processed forms of agricultural commodities. the supply of processed commodities is presumed to remain unaffected as the processing would have likely happened at some time in the past. Further non-delivery on contracts to international clients often has serious costs in terms of reputation. For these reasons one would not expect negative impacts of demonetization. We focus on five varieties of coffee (robusta, arabica, plantation, ground, instant) and five oilmeals (soyabean, rapeseed, groundnut, ricebran, castor seed) . A robustness check for coffee exports (five varieties) and oil meals exports all show no effects when a similar difference in differences strategy is adopted using monthly export data from 2012-2017. Results from these tests, reported in Table 7 suggest that by and large these lend credence to our arguments.

The results from the difference in differences also suggested that commodities where there is government intervention may have been affected to a lesser extent. We focus on milk marketing in Maharashtra, where three types of buyers dominate, the government dairies, private dairies and farmer owned and managed dairy cooperatives. This allows us to check if procurement by government has a cushioning influence on the potential negative impacts. In the case of milk, we find, as expected, that government procurement of milk shows no impacts (Table 7). However ,procurement by private players and cooperatives are impacted suggesting that the latter likely faced cash shortages in the wake of demonetization. Similarly, the results on procurement of grain are consistent with the patterns found in the mandi data. Paddy procurement before milling is higher post-demonetization relative to other years and to before demonetization, but this is not the case with other grains. These estimations use monthly data and do not control for rainfall and are hence best interpreted as a consistency check in a general sense.

We also analyze data on the quantity and value traded on the National Commodities and Derivatives Exchange (NCDEX) to see if the patterns of impacts on select commodities are consistent with those from mandi trades. While overall trade on the NCDEX (both agriculture and non-agricultural commodities) declined (results not shown here), we conducted the analysis for an illustrative list of commodities comprising wheat (foodgrain), soyabean (oilseed/pulse), cotton (fibre) and turmeric (spice) that had adequate data (Table 7 ). We find, as with the results for mandi, cotton and wheat show no impacts whereas the impact on turmeric and soyabean is quite substantial with the value traded showing a larger negative impact relative to quantity, suggesting that prices were impacted as well. these patterns correspond broadly to the results for mandis. 
One concern with attributing impacts from the analysis to demonetization is the contemporaneous election of a new president in the United States. We believe this is not a concern for several reasons. Other than a few commodities that are integrated with global markets, most agricultural commodities in India are somewhat insulated from world trade. There is not much evidence that the US elections impacted agricultural commodity markets worldwide. Given that India is not a key trading partner with the US for most agricultural commodities, this is perhaps an unlikely confounding factor. Existence evidence suggests a 0.9 to $1.5 \%$ decline in soy, corn and wheat futures on November 9, 2016, attributed to the election results in the US, but nothing beyond.

While our research suggests that there is an impact on many commodities, this effect may be overestimated if one believes that farmers are diverting trade away from mandis to local markets. In this case, the impacts estimated here represent at least in part displacement of trade rather than destruction of trade. In the absence of reliable data it is difficult to get a sense of the extent of displacement. ${ }^{42}$ Even with these caveats, it is possible that our estimates of trade displacement potentially seriously underestimates actual welfare losses to farmers. If, as our field based evidence suggest, transactions did occur at specified prices, but there was only an exchange of goods but not of money with traders promising farmers to pay them in 4 or 5 months, the time lag between trade and payments entails a significant loss of income. To tide over the cash crunch and transacting virtually fully on credit, many farmers were borrowing from informal lenders at very high interest rates / consumption loans. ${ }^{43}$ If this is the case, one would expect any negative impacts of demonetization to manifest with a lag akin to a "sleeper effect".

We stop short of estimating longer term consequences of demonetization because beyond three months it is difficult to gauge whether we are seeing second round effects of responses to demonetization rather than demonetization itself. For example, if farmers were holding out to cope with demonetization, it could well be that arrivals cause potential glut in the markets as all the stored stocks make their way into the market within a narrow window, thereby bringing down prices. It could also be the reverse that price declines post-demonetization attract traders and processors, presumably with better access to credit or financial resources, wish to take advantage of the low prices to buy up stocks, leading to the opposite effect and crowding in trade at the mandi. It is virtually impossible to parse these effects through secondary data. In addition, the anticipation of the introduction of Goods and Services Tax (GST) complicates clean identification beyond a certain window. ${ }^{44}$ These caveats are relevant while interpreting the results of our analysis.

\footnotetext{
${ }^{42}$ Estimating outside-mandi trade based on marketed surplus estimates applied to secondary data on production are notoriously unreliable in the context of Indian agriculture .

${ }^{43}$ As one farmer in the southern state of Tamil Nadu put it "today, anyone who has cash (that is legal tended) is a money lender" January 07, 2017 Field visit, Madurai/Trichy.

${ }^{44}$ Goods and Services Tax (GST) is an indirect tax introduced countrywide on 1 July 2017 replacing multiple cascading taxes by the federal and state governments.
} 


\section{Concluding Remarks}

This paper set out to evaluate the short term impacts of demonetization on domestic agricultural trade. Using difference in differences techniques using past years data as controls, we attempt to isolate the impact of demonetization. We find that demonetization displaced over $15 \%$ of daily trade on average, the effect tapering off only gradually over the 90 day window. Trade in perishables, for example, was displaced to the extent of $23 \%$ in the week following demonetization. It recovered slightly by the end of 90 days, but was still $18 \%$ lower than the usual. Much of this in on account of a collapse in prices, relative to arrivals - which seem to have recovered over the three month period studied. The price declines are particularly intense for perishables and seems to have persisted beyond the window analyzed. There are significant differences across commodities but almost all of these are in expected ways. The impacts are sharpest for kharif crops where government intervention is minimal and least for perishables and crops where farmers are well organized or where governments actively procure. The impacts estimated in this paper offer insights into the the slowdown in GDP growth rates in the three quarters following demonetization.

The findings also provide some understanding of the farmer discontent in recent months across the country. ${ }^{45}$ Often the consequences of monetary policy for the agricultural sector (and perhaps other informal) sectors are left unexamined, likely because of the huge challenges in securing the data to generate these assessments. Early commentaries suggested that perhaps not Chand and Singh (2016). The Economic Survey of India 2016-17, for example, concluded with cautious optimism that perhaps the impacts of demonetization on agriculture had been overstated. "Contrary to early fears, as of January15, 2017 aggregate sowing of the two major rabi crops - wheat and pulses (gram)-exceeded last year's planting by 7.1 percent and 10.7 percent. "(Government of India, 2016a). Yet it would seem that these impacts estimated in this paper suggest significant welfare consequences for farmers. As of 2016-17, horticulture production at 300 million tonnes outstripped the production of foodgrains (275 million tonnes). If indeed horticulture trade saw impacts of the magnitude estimated in this paper, especially without improvements even after three months postdemonetization, one would expect this to reflect perhaps with a lag. It is interesting that although rabi sowing and production were healthy, in the immediate aftermath of demonetization, it turns out there are marked declines in sowing for the kharif season 2017-18 as of September 2017. These shortfalls in sowing figures, despite adequate and timely rainfall, is suggestive then, perhaps, of a lagged response to the monetary shock of demonetization (Table 6).

If, as pointed out in the earlier section, farmers rely on borrowings at usurious interest rates, then the negative consequences of trade displacement could be higher than implied by our estimates. There exist ample evidence on poverty traps that suggest that in the absence of markets for credit and insurance, shocks can push people into poverty and entrap them (Azariadis and Stachurski,

\footnotetext{
${ }^{45}$ Several states have seen farmer protests - including Madhya Pradesh, Tamil Nadu, Rajasthan, Maharashtra in recent months.
} 
2005; Bowles et al., 2006; Carter and Barrett, 2006; Carter et al., 2007; Krishna, 2004). If on the other hand, demonetization engineers a transformation of the financial landscape in a way that farmers are integrated into the formal banking system, this could hold benefits in the long run in ways that may counterbalance these losses. Whether or how much farmers welfare is impacted remains to be seen, but the results from our analysis point to lingering impacts of demonetization on farmers and overall adverse distributional consequences overall. 


\section{References}

Abadie, A., Diamond, A., Hainmueller, J., 2010. Synthetic control methods for comparative case studies: Estimating the effect of california?s tobacco control program. Journal of the American statistical Association 105(490), 493-505.

Abadie, A., Diamond, A., Hainmueller, J., et al., 2014. Synth: Stata module to implement synthetic control methods for comparative case studies. Statistical Software Components .

Abadie, A., Gardeazabal, J., 2003. The economic costs of conflict: A case study of the basque country. The American Economic Review 93(1), 113-132.

Aggarwal, N., Jain, S., Narayanan, S., 2017. The long road to transformation of agricultural markets in india: Lessons from karnataka. Economic and Political Weekly 52(41), 47-55.

Aggarwal, N., Narayanan, S., 2016. Demonetisation and agricultural markets.

Azariadis, C., Stachurski, J., 2005. Poverty traps. Handbook of economic growth 1, 295-384.

Banerjee, A., Kala, N., 2017. The economic and political consequences of india's demonetisation.

Belongia, M. T., 1991. Monetary policy and the farm/nonfarm price ratio: a comparison of effects in alternative models. Federal Reserve Bank of St. Louis Review 73(July/August 1991).

Bowles, S., Durlauf, S. N., Hoff, K., 2006. Poverty traps. Princeton University Press.

Carter, M. R., Barrett, C. B., 2006. The economics of poverty traps and persistent poverty: An asset-based approach. The Journal of Development Studies 42(2), 178-199.

Carter, M. R., Little, P. D., Mogues, T., Negatu, W., 2007. Poverty traps and natural disasters in ethiopia and honduras. World development 35(5), 835-856.

Chadha, N., Das, A., Gangopadhyay, S., Mehta, N., 2017. Reassessing the impact of demonetisaition on agriculture and informal sector. RACE, IDF, January 2017 .

Chambers, R. G., 1984. Agricultural and financial market interdependence in the short run. American Journal of Agricultural Economics 66(1), 12-24.

Chambers, R. G., Just, R. E., 1982. An investigation of the effect of monetary factors on agriculture. Journal of Monetary Economics 9(2), 235-247.

Chand, R., Singh, J., 2016. Agricultural growth after demonetization.

Ciriacy-Wantrup, S. V., 1940. The relation of war economics to agriculture with particular reference to the effects of income and price inflation and deflation. The American Economic Review 30(1), $366-382$. 
Diaz-Bonilla, E., Robinson, S., 2010. Macroeconomics, macrosectoral policies, and agriculture in developing countries. Handbook of agricultural economics 4, 3035-3213.

Ghosh, J., Chandrasekhar, C., Patnaik, P., 2017. Demonetisation Decoded: A Critique of India's Currency Experiment. Taylor \& Francis.

Government of India, 2016a. Price policy for kharif crops, agricultural marketing year 2017-18.

Government of India, 2016b. State of agriculture in india 2015-16.

Hamilton, J. D., 1987. Monetary factors in the great depression. Journal of Monetary Economics 19(2), $145-169$.

Krishna, A., 2004. Escaping poverty and becoming poor: who gains, who loses, and why? World development 32(1), 121-136.

Krishnamurthy, M., 2017. Trading notes. Hot Spots, Cultural Anthropology website .

Miskimin, H. A., 1964. Monetary movements and market structure-forces for contraction in fourteenth- and fifteenth-century england. The Journal of Economic History 24(4), 470-490.

Reddy, C. R., 2017. Demonetisation and the Black Economy. Orient Blackswan, Delhi.

Schuh, G. E., 1974. The exchange rate and us agriculture. American Journal of Agricultural Economics 56(1), 1-13. 


\section{A Synthetic Control Method}

We use synthetic control methods to overcome the disadvantages of a difference in differences technique that presumes that unobservable differences between the comparison crop years 2011-12 to 2015-16 and treatment year 2016-17 are time invariant. We construct a synthetic control for 2016-17 to serve as a counterfactual and use it to predict the value of trade post demonetization. This synthetic control is constructed as a weighted combination of value of trade for each day, drawing on the donor pool of control years (2011-12 to 2015-16). The approach was pioneered by Abadie et al. (2010); Abadie and Gardeazabal (2003); Abadie et al. (2014).

To implement this approach, we compute the total value of trade in each mandi over a week, multiplying the minimum price and the total quantity, and aggregating it over all commodities over a week. This yields a dataset that has the total weekly value of trade, mandi-wise, in the country. Weekly data is smoother and enables us to obtain a synthetic control that is a better fit for the year of demonetization. As mentioned, in the synthetic control model, we use a donor pool comprising the years 2011-12 to 2015-16. The mean value of arrivals is shown for these years is shown in Figures 11 and 10. These suggests variations within season in arrivals but broadly comparable trade patterns across seasons. We use rainfall data upto 12 lagged months and account for all festivals during the year and control for whether the week coincided with any festival, the number of reporting mandis and the distribution of days of the week in these weekly data. In the version reported here, we truncate the weeks prior to demonetization such that we get a better fit of the synthetic control.

Figure 12 suggests a significant dip in post-November 8 value of trade (week 44 in the figure), amounting to as much as Rs.350 crores of trade per mandi per week at its worst. By end-December (week 50), there is a recovery so that the actual value of trade is higher than the predicted value. Overall however at that time, this is not enough to counterbalance the losses up until that period.

We also repeat this exercise using an alternate metric, i.e., computing an average daily value, mandi-wise the average computed over the week. We find similar results - a negative impact in the weeks following demonetization and recovery around week $50 .{ }^{46}$ In general, the synthetic control replicates the pre-Nov 8 figures closer to the start of the season than it does for early. The two methods assign the largest weights to different comparison years. While for the mean daily value of trade, the maximum weights are assigned to 2011 (0.523) and 2014 (0.2) with 2013 getting 0, for the sum of weekly trade, the year 2012 and 2013 get the highest weights of 0.706 and 0.273 with 2014 assigned 0. The years that contribute to synthetic control are therefore different, but these years are perhaps closest to 2016-17 from the perspective of value of mandi based time over the season.

\footnotetext{
${ }^{46}$ At the time of publishing this work, we are replicating this for daily total value of agricultural trade. We are also working to extend the period of analysis post demonetization.
} 
Figure 10 Total value of trade, by week, for donor pool years

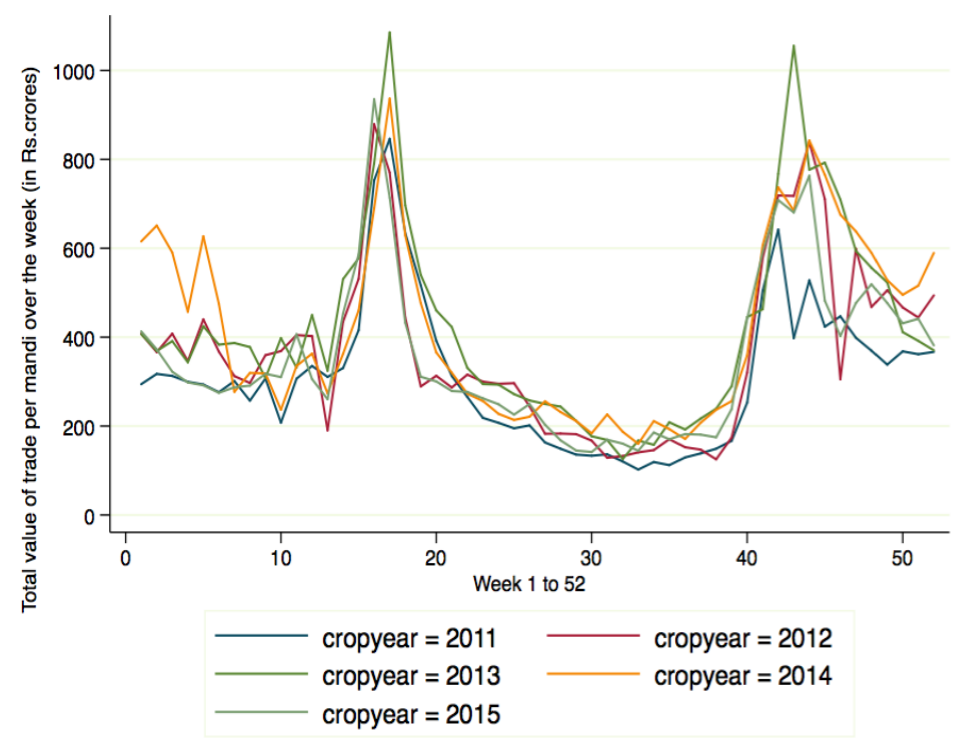

Figure 11 Mean value of trade, by week, for donor pool years

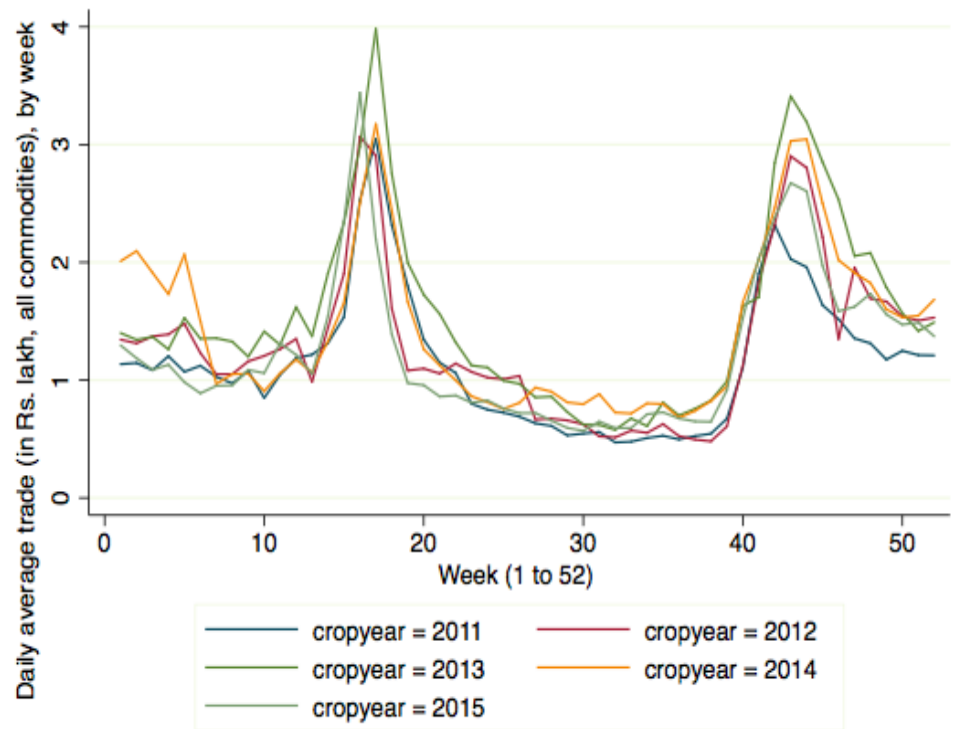




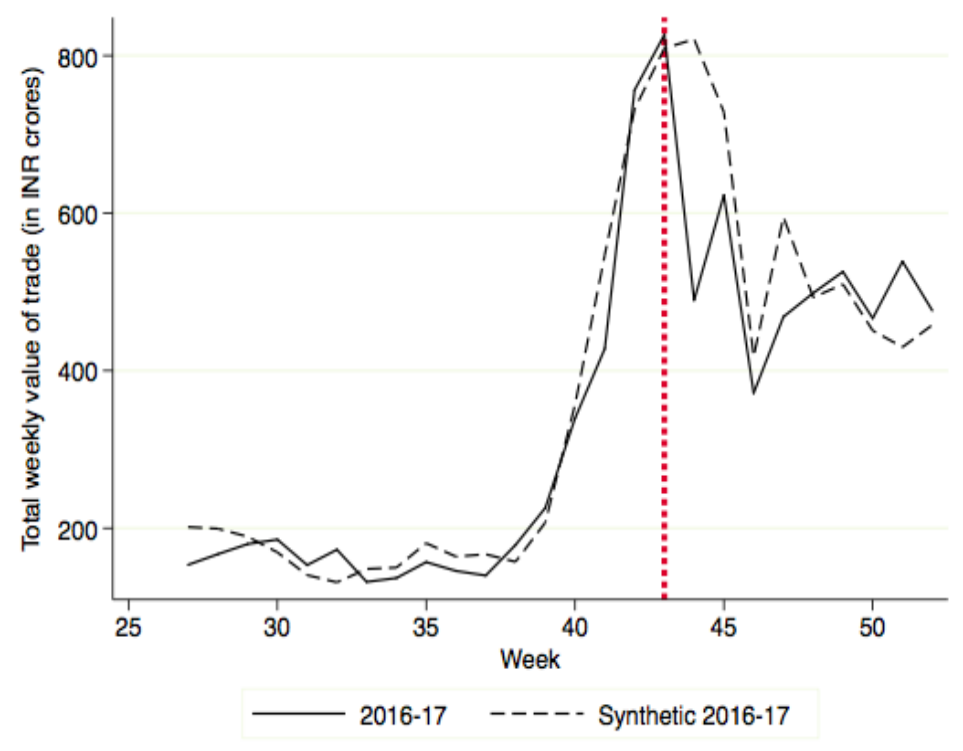

Source: Computed by authors

We conduct a placebo using 2015-16. ${ }^{47}$ If the impacts for the analysis for 2016-17 are indeed on account of demonetization, a synthetic control approach, when applied to 2015-16, should be such that the synthetic and actual 2015-16 are not very different from each other given that 2 there was no demonetization on November 8 of 2015. Using the donor pool years (2011-12 to 2014-15) we find that this is indeed the case (Figure 14). Although the synthetic 2015-16 does not track arrivals in the early weeks, it offers an accurate fit beyond week 20. This suggests that the impact we see in Figures 12 and 13 are on account of demonetization. The extent of impacts are more or less consistent with the difference-in-differences estimates, which therefore seem to yield credible estimates of impacts.

\footnotetext{
${ }^{47}$ We present the placebo for 2015 -16 and not for other years, merely as an illustration of our robustness checks.
} 
Figure 13 Synthetic Control (Mean daily value of trade)

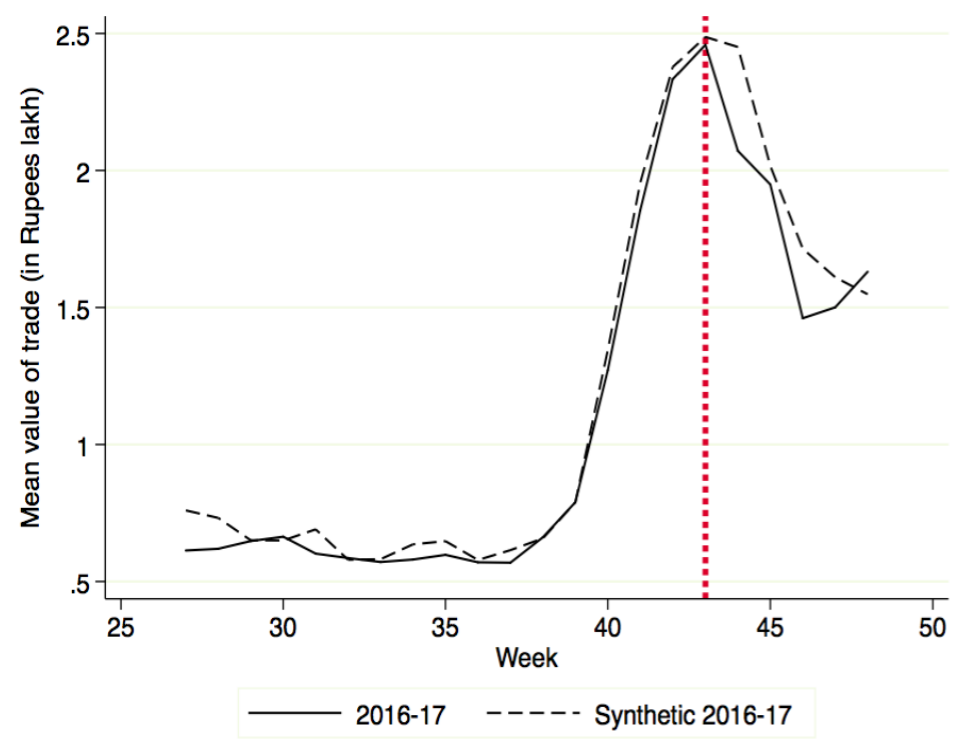

Source: Computed by authors

Figure 14 Synthetic Control : Placebo using 2015-16 mean daily value of trade

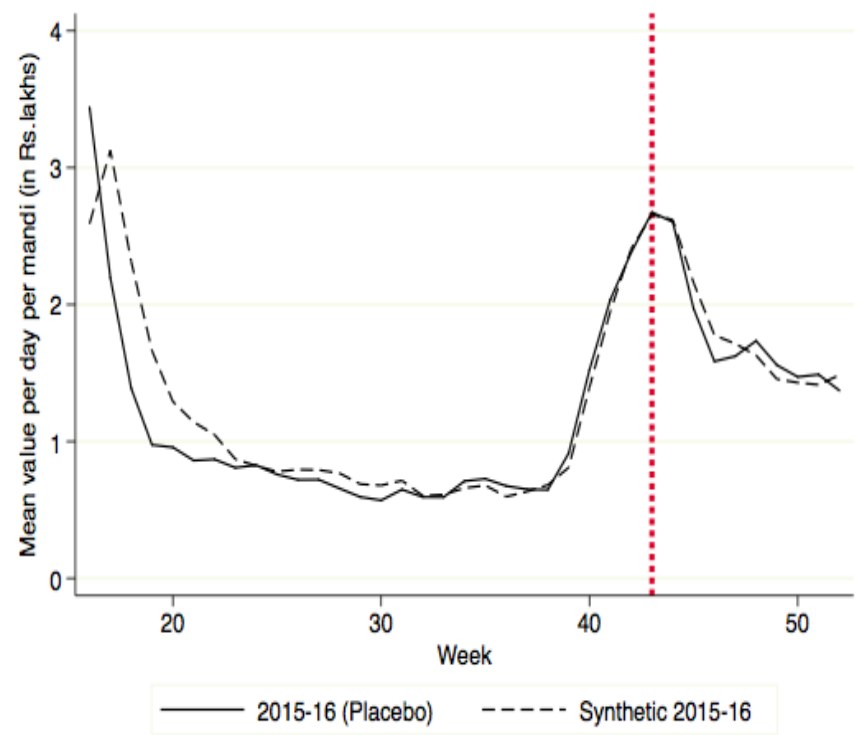

Source: Computed by authors 
B Tables 
Table 1 How was production in 2016-17 compared to 2003-04 to 2015-16?

This table provides a comparative perspective of production in 2016 in relation to the years 2003-04 to 2015-16. We compare the 2016 production with the minimum, maximum and mean of these years and deem 2016 to have been better if production exceeded the maximum for that period.

\begin{tabular}{|c|c|c|c|c|c|c|c|}
\hline Crop & season & Units & 2016 production & Minimum & Maximum & Mean & Was 2016 better? \\
\hline Rice & Rice (kharif) & mill. tonnes & 93.88 & 72.23 & 92.78 & 84.1 & Better \\
\hline Wheat & Rabi & mill. tonnes & & 68.64 & 95.85 & 82.9 & \\
\hline Jowar & Jowar (kharif) & mill. tonnes & 2.42 & 1.71 & 4.84 & 3.3 & \\
\hline Bajra & $\begin{array}{l}\text { Pearl Millet } \\
\text { Bajra }\end{array}$ & mill. tonnes & 8.55 & 6.51 & 12.11 & 9.0 & \\
\hline Maize & Maize (kharif) & mill. tonnes & 19.3 & 11.48 & 17.14 & 14.5 & Better \\
\hline Ragi Finger millet & Ragi, kharif & mill. tonnes & 1.85 & 1.44 & 2.43 & 2.0 & \\
\hline Small Millets & Kharif & mill. tonnes & 0.34 & 0.37 & 0.56 & 0.5 & \\
\hline Coarse Cereals & Kharif & mill. tonnes & 32.45 & 23.83 & 33.08 & 29.2 & \\
\hline Tur & Kharif & mill. tonnes & 4.29 & 2.27 & 3.17 & 2.7 & Better \\
\hline Urad & Kharif & mill. tonnes & 2.01 & 0.81 & 1.43 & 1.1 & Better \\
\hline Moong & Kharif & mill. tonnes & 1.35 & 0.44 & 1.53 & 1.0 & \\
\hline Other Kharif & Kharif & mill. tonnes & 1.06 & 0.49 & 1.33 & 0.8 & \\
\hline Groundnut & Kharif & lakh tonnes & 64.98 & 31.87 & 80.58 & 56.0 & \\
\hline Castorseed & Kharif & lakh tonnes & 17.31 & 7.62 & 22.95 & 13.4 & \\
\hline Sesamum & Kharif & lakh tonnes & 6.75 & 5.88 & 8.93 & 7.3 & \\
\hline Nigerseed & Kharif & lakh tonnes & 1.01 & 0.76 & 1.21 & 1.0 & \\
\hline Rapeseed-Mustard & Rabi & lakh tonnes & & 58.34 & 81.79 & 71.5 & \\
\hline Linseed & Rabi & lakh tonnes & & 1.32 & 1.97 & 1.6 & \\
\hline Sunflower & Kharif & lakh tonnes & 1.34 & 0.68 & 4.63 & 2.7 & \\
\hline Soyabean & Kharif & lakh tonnes & 142.23 & 68.76 & 146.66 & 102.4 & \\
\hline Cotton & Total & lakh bales\# & 321.23 & 137.29 & 359.02 & 266.7 & \\
\hline Jute & Total & lakh bales & 99.05 & 93.99 & 112.3 & 102.9 & \\
\hline Mesta & Total & lakh bales & 5.01 & 5.08 & 9.9 & 7.3 & \\
\hline Sugarcane & Total & lakh tonnes & 3052.46 & 2338.62 & 3623.33 & 3188.0 & \\
\hline Cereals & Kharif & mill. tonnes & 126.33 & 98.59 & 125.22 & 113.2769 & Better \\
\hline Total Pulses & Kharif & mill. tonnes & 8.7 & 4.2 & 7.12 & 5.552308 & Better \\
\hline Total Foodgrains & Kharif & milli. tonnes & 135.03 & 103.31 & 131.27 & 118.8277 & Better \\
\hline Total Nine Oilseeds & Kharif & lakh tonnes & 233.63 & 140.12 & 226.12 & 182.8054 & Better \\
\hline Jute-Mesta & Total & lakh bales & 104.05 & 102.72 & 118.17 & 110.14 & \\
\hline Sugarcane & Total & lakh tonnes & 3052.46 & 2338.62 & 3623.33 & 3188.014 & \\
\hline Cotton & Total & lakh bales\# & 321.23 & 137.29 & 359.02 & 266.7269 & \\
\hline
\end{tabular}


Table 2 Commodities selected for analysis

The table presents the list of commodities selected for the analysis. Arrivals during Kharif is computed as percentage of arrivals during October to January in a crop year. Average across 2012-2016 is reported. Mandis reported is computed as number of unique mandis that reported arrivals in a crop year.

\begin{tabular}{|c|c|c|c|c|c|}
\hline Commodity & Commodity group & $\begin{array}{c}\text { Area under cultivation } \\
(2015-16, \text { in million hectares })\end{array}$ & $\begin{array}{l}\text { \# of mandis } \\
\text { reporting trade }\end{array}$ & Season & $\begin{array}{c}\text { Arrivals } \\
\text { during Kharif (\%) }\end{array}$ \\
\hline Bajra & Cereals & 6.98 & 451 & Kharif & 49.18 \\
\hline Jowar & Cereals & 5.65 & 453 & & 37.84 \\
\hline Maize & Cereals & 8.69 & 778 & Kharif & 56.10 \\
\hline Paddy & Cereals & 43.39 & 1,098 & Kharif & 77.70 \\
\hline Ragi & Cereals & NA & 104 & Kharif & 35.14 \\
\hline Rice & Cereals & NA & 506 & & 35.75 \\
\hline Wheat & Cereals & 30.23 & 1,170 & Rabi & 9.60 \\
\hline Bengal Gram & Pulses & 8.35 & 549 & Rabi & 17.92 \\
\hline Arhar & Pulses & 3.75 & 519 & Kharif & 34.73 \\
\hline $\begin{array}{l}\text { Pigeon Pea } \\
\text { (arhar/tur) }\end{array}$ & Pulses & included above & 11 & Kharif & 50.08 \\
\hline Soyabean & Oilseeds & 11.67 & 473 & Kharif & 63.11 \\
\hline Mustard & Oilseeds & 5.76 & 591 & Rabi & 16.63 \\
\hline Groundnut & Oilseeds & 4.56 & 376 & Kharif & 54.52 \\
\hline Cumin & Spices & 0.70 & 85 & Rabi & 13.51 \\
\hline Coriander Seed & Spices & 0.62 & 142 & & 17.84 \\
\hline Dry Chillies & Spices & 0.79 & & & 24.67 \\
\hline Turmeric & Spices & 0.19 & 102 & & 19.37 \\
\hline Turmeric raw & Spices & included above & 19 & Kharif & 85.20 \\
\hline Arecanut & Plantation & 0.47 & 94 & & 38.42 \\
\hline Cashewnuts & Plantation & 1.04 & 53 & & 7.37 \\
\hline Copra & Plantation & 2.09 & 65 & & 40.24 \\
\hline Cotton & Fibre & 11.87 & 476 & Kharif & 64.15 \\
\hline Sugarcane & Sugar & 4.95 & 10 & & 10.47 \\
\hline Brinjal & Vegetable & 0.66 & 665 & & 34.47 \\
\hline Cabbage & Vegetable & 0.39 & 542 & & 39.63 \\
\hline Cauliflower & Vegetable & 0.43 & 562 & & 45.86 \\
\hline Okra & Vegetable & 0.49 & 556 & & 21.29 \\
\hline Onion & Vegetable & 1.23 & 859 & & 34.02 \\
\hline Potato & Vegetable & 2.13 & 860 & & 34.98 \\
\hline Tomato & Vegetable & 0.76 & 744 & & 33.34 \\
\hline Apple & Fruits & 0.31 & 347 & & 50.04 \\
\hline Banana & Fruits & 0.85 & 460 & & 34.32 \\
\hline Guava & Fruits & 0.25 & 196 & & 53.97 \\
\hline Lemon & Fruits & 0.26 & 250 & & 23.18 \\
\hline Lime & Fruits & included above & 72 & & 30.11 \\
\hline Sweet Lime & Fruits & 0.22 & 203 & & 21.83 \\
\hline Orange, others & Fruits & 0.46 & 226 & & 73.01 \\
\hline
\end{tabular}


Table 3 Diwali dates during 2011-12 to 2016-17

\begin{tabular}{lr} 
Crop year & Diwali date \\
\hline $2011-12$ & $2011-10-26$ \\
$2012-13$ & $2012-11-13$ \\
$2013-14$ & $2013-11-03$ \\
$2014-15$ & $2014-10-23$ \\
$2015-16$ & $2015-11-11$ \\
$2016-17$ & $2016-10-30$ \\
\hline
\end{tabular}

Table 4 Heterogeneous impacts on value of trade after demonetization

The table presents impacts on the value of trade for days 1, 7, 15, 21, 30, 45, 60, 75, 90 days after demonetization. The first column shows results for pooled regression and third and fourth show results for subgroups kharif and rabi crops, and the fifth and sixth for non-perishables and perishables.

\begin{tabular}{|c|c|c|c|c|c|}
\hline \multicolumn{6}{|c|}{ With controls for commodity, mandi fixed effects } \\
\hline Days & Pooled & Kharif & Rabi & Non-perishables & Perishables \\
\hline 1 & $-0.102^{* * *}$ & -0.009 & -0.017 & $-0.059 * *$ & $-0.114^{* * *}$ \\
\hline 7 & $-0.149 * * *$ & $-0.050^{* *}$ & $-0.151^{* * *}$ & $-0.111^{* * *}$ & $-0.167^{* * *}$ \\
\hline 15 & $-0.132^{* * *}$ & 0.020 & $-0.131^{* * *}$ & $-0.077^{* * *} *$ & $-0.200^{* * *}$ \\
\hline 21 & $-0.112^{* * *}$ & $0.070^{* * *}$ & $-0.055^{* * *}$ & $-0.046^{* * *}$ & $-0.210^{* * *}$ \\
\hline 30 & $-0.096 * * *$ & $0.105^{* * *}$ & $0.037^{* * *}$ & $-0.030 * * *$ & $-0.217^{* * *}$ \\
\hline 45 & $-0.087^{* * *}$ & $0.113^{* * *}$ & $0.065^{* * *}$ & $-0.023 * * *$ & $-0.215^{* * *}$ \\
\hline 60 & $-0.080^{* * *}$ & $0.109 * * *$ & $0.057^{* * *}$ & $-0.019 * * *$ & $-0.203^{* * *}$ \\
\hline 75 & $-0.070^{* * *}$ & $0.113^{* * *}$ & $0.066^{* * *}$ & $-0.010^{*}$ & $-0.190^{* * *}$ \\
\hline 90 & $-0.070^{* * *}$ & $0.100^{* * *}$ & $0.068^{* * *}$ & $-0.013^{* *}$ & $-0.183^{* * *}$ \\
\hline \multicolumn{6}{|c|}{ Without controls for commodity, with mandi fixed effects } \\
\hline Days & Pooled & Kharif & Rabi & Non-perishables & Perishables \\
\hline 1 & $-0.120^{* * *}$ & -0.021 & -0.006 & $-0.061^{* *}$ & $-0.122^{* * *}$ \\
\hline 7 & $-0.163^{* * *}$ & $-0.069^{* *}$ & $-0.135^{* * *}$ & $-0.104^{* * *}$ & $-0.163^{* * *}$ \\
\hline 15 & $-0.140^{* * *}$ & 0.005 & $-0.115^{* * *}$ & $-0.066^{* * *}$ & $-0.199 * * *$ \\
\hline 21 & $-0.117^{* * *}$ & $0.058^{* * *}$ & $-0.039 * *$ & $-0.031^{* * *}$ & $-0.211^{* * *}$ \\
\hline 30 & $-0.099 * * *$ & $0.085 * * *$ & $0.049 * * *$ & $-0.018^{* *}$ & $-0.214^{* * *}$ \\
\hline 45 & $-0.086^{* * *}$ & $0.097^{* * *}$ & $0.077^{* * *}$ & -0.011 & $-0.212^{* * *}$ \\
\hline 60 & $-0.078 * * *$ & $0.097^{* * *}$ & $0.069 * * *$ & -0.006 & $-0.200^{* * *}$ \\
\hline 75 & $-0.071^{* * *}$ & $0.099 * * *$ & $0.076^{* * *}$ & 0.001 & $-0.188 * * *$ \\
\hline 90 & $-0.072^{* * *}$ & $0.084^{* * *}$ & $0.078^{* * *}$ & -0.004 & $-0.181^{* * *}$ \\
\hline
\end{tabular}

${ }^{1}$ Coefficients from estimation of minimum value of transactions in each mandi each day

2 Significance level: $* * *$ is $1 \%, * *$ is $5 \%$ and $*$ is $10 \%$ 
Table 5 Weekly changes in arrivals prior and post demonetization

The table below shows one and two weeks changes in arrivals vis-a-vis the week prior demonetization. Columns 2 and 3 show the change for 2016-17, that is the year of demonetization. The next two columns show the average change around the same date for the remaining years. Since Diwali can have a significant impact on arrivals, the weekly changes for the remaining years are also shown by excluding the impact of Diwali (Column 6 and 7 ). This is done by excluding three days prior and three days post Diwali if the date of Diwali falls within the weeks analyzed around demonetization. The last columns shows the proportion of arrivals that come during the kharif season for each of the sample commodities. All values are presented as percentage of arrivals in the week prior demonetization.

\begin{tabular}{|c|c|c|c|c|c|c|c|}
\hline \multirow[b]{2}{*}{ Commodity } & \multicolumn{2}{|c|}{ Treatment year (2016-17) } & \multicolumn{2}{|c|}{ Control years (with Diwali) } & \multicolumn{2}{|c|}{ Control years (w/o Diwali) } & \multirow{2}{*}{$\begin{array}{l}\text { Kharif } \\
\text { arrivals }\end{array}$} \\
\hline & Post 1 week & Post 2 weeks & Post 1 week & Post 2 weeks & Post 1 week & Post 2 weeks & \\
\hline Paddy & -41.99 & -30.55 & -32.55 & -28.66 & -35.72 & -36.96 & 77.07 \\
\hline Maize & -43.19 & -8.59 & -12.66 & 33.84 & 8.33 & 24.22 & 56.10 \\
\hline Bajra & -54.62 & -31.53 & -3.91 & 25.79 & -2.96 & 6.26 & 49.18 \\
\hline Jowar & -66.10 & -55.09 & -9.27 & 38.92 & 11.65 & 24.15 & 37.84 \\
\hline Rice & -15.08 & 22.71 & 5.38 & 43.51 & 8.46 & 32.82 & 35.74 \\
\hline Ragi & -13.59 & -17.32 & -3.81 & 14.54 & 12.67 & 2.81 & 35.15 \\
\hline Wheat & -41.89 & -44.57 & -1.46 & 31.52 & -1.01 & 3.72 & 9.60 \\
\hline Soyabean & -86.05 & -76.24 & -14.08 & 19.75 & -7.14 & -7.29 & 63.11 \\
\hline Groundnut & -54.36 & -32.98 & 18.19 & 67.48 & -5.18 & 15.06 & 54.53 \\
\hline Mustard & -46.94 & -44.35 & -4.69 & 21.04 & -2.83 & -5.35 & 16.63 \\
\hline Turmericraw & -14.17 & 40.76 & -20.28 & 54.51 & -19.67 & 33.58 & 85.20 \\
\hline Dry Chilli & -14.31 & 28.46 & -3.53 & 33.31 & 7.07 & 41.08 & 24.67 \\
\hline Turmeric & -55.50 & -53.08 & 62.21 & 152.33 & 71.59 & 152.02 & 19.37 \\
\hline Coriander seed & -80.46 & -74.54 & 2.40 & 72.74 & 22.06 & 21.67 & 17.84 \\
\hline Cumin & -54.48 & -64.13 & 33.33 & 208.35 & 14.46 & 102.05 & 13.51 \\
\hline Arhar & -34.76 & 19.15 & -11.17 & 19.72 & -4.87 & 16.75 & 34.74 \\
\hline Bengal Gram & -68.39 & -50.21 & -7.22 & 34.48 & -0.69 & 12.06 & 17.92 \\
\hline Copra & -48.29 & -13.03 & 1.24 & 26.49 & -11.83 & 1.40 & 40.25 \\
\hline Arecanut & -31.91 & 9.64 & 1.88 & 58.11 & 11.65 & 62.41 & 38.42 \\
\hline Cashewnuts & -21.73 & 30.22 & 22.23 & 62.64 & 11.66 & 62.55 & 7.37 \\
\hline Cotton & -31.10 & 3.20 & 11.61 & 55.07 & 4.58 & 29.48 & 64.15 \\
\hline Cotton Seed & 65.88 & 176.71 & 601.11 & 1812.72 & 615.67 & 1809.29 & 57.15 \\
\hline Apple & -21.47 & -41.16 & 16.98 & 55.15 & 5.79 & 21.18 & 50.04 \\
\hline Orange & 10.32 & -37.18 & 14.08 & 33.49 & 4.59 & 26.11 & 73.01 \\
\hline Guava & 33.43 & 105.08 & 38.39 & 98.16 & 68.51 & 101.63 & 53.98 \\
\hline Banana & 21.67 & 70.98 & -4.48 & 5.52 & -8.70 & -6.78 & 34.32 \\
\hline Cauliflower & 7.63 & 46.02 & 3.47 & 37.24 & 7.60 & 38.07 & 45.86 \\
\hline Cabbage & -9.75 & 23.44 & -2.61 & 24.52 & 1.43 & 21.70 & 39.63 \\
\hline Potato & -2.58 & 19.73 & 0.77 & 30.73 & 1.79 & 23.92 & 34.98 \\
\hline Brinjal & -9.95 & 18.65 & -5.46 & 25.70 & 2.53 & 27.58 & 34.47 \\
\hline Onion & -6.19 & 7.69 & 4.80 & 38.98 & 2.45 & 20.26 & 34.02 \\
\hline Tomato & -7.49 & 19.83 & -6.53 & 20.23 & -3.54 & 16.53 & 33.34 \\
\hline Okra & -8.05 & 14.00 & -17.88 & -3.34 & -19.00 & -9.56 & 21.30 \\
\hline Lime & -9.10 & -5.06 & -13.04 & 68.01 & -19.10 & 51.01 & 30.12 \\
\hline Lemon & 21.26 & -10.45 & -27.45 & 1.05 & -20.84 & 8.15 & 23.18 \\
\hline Sweet Lime & -18.31 & -18.74 & 0.36 & 21.03 & -5.81 & 2.30 & 21.83 \\
\hline
\end{tabular}


Table 6 Kharif and rabi sowing, 2016-17 and 2017-18

The table presents the area sown in kharif 2017-18 (as on 22.09.2017) and rabi 2016-17 (as on 03.02.2017).

\begin{tabular}{|c|c|c|c|c|}
\hline & \multicolumn{2}{|c|}{ Kharif sowing \%age change } & \multicolumn{2}{|c|}{ Rabi sowing \%age change } \\
\hline & $2016-17$ & (5 yr-avg.) & $2015-16$ & (5 yr-avg.) \\
\hline \multicolumn{5}{|l|}{ Cereals } \\
\hline \multirow{2}{*}{$\begin{array}{l}\text { Wheat } \\
\text { Rice }\end{array}$} & & & 6.9 & 4.5 \\
\hline & -1.3 & -4.8 & -11.7 & -41.2 \\
\hline Pulses & -3.5 & 33.7 & 11.2 & 13.5 \\
\hline Gram & & & 10.7 & 12.0 \\
\hline \multirow{2}{*}{$\begin{array}{l}\text { Arhar } \\
\text { urad }\end{array}$} & -18.0 & 10.2 & 21.2 & 12.6 \\
\hline & 21.6 & 72.9 & 9.0 & 13.8 \\
\hline Moong & -8.0 & 35.5 & 3.4 & -30.5 \\
\hline Fieldpea & & & 17.4 & 18.4 \\
\hline Kulthi & 6.1 & -71.0 & -10.9 & 68.0 \\
\hline Lathyrus & & & 9.6 & -17.4 \\
\hline Other pulses & -2.0 & 43.9 & 12.1 & 160.9 \\
\hline \multirow{2}{*}{$\begin{array}{l}\text { Coarse cereals } \\
\text { Jowar }\end{array}$} & -2.5 & -3.5 & -5.6 & -11.6 \\
\hline & -7.4 & -22.4 & -13.9 & -15.8 \\
\hline & 1.9 & -6.5 & 9.3 & -93.5 \\
\hline $\begin{array}{l}\text { Bajra } \\
\text { Ragi }\end{array}$ & 1.0 & -12.1 & -33.4 & -12.7 \\
\hline Maize & -4.8 & 9.3 & 9.4 & 5.6 \\
\hline Small millets & -10.9 & -27.8 & & \\
\hline Barley & & & 7.5 & 18.8 \\
\hline \multirow{4}{*}{$\begin{array}{l}\text { Oilseeds } \\
\text { Groundnut } \\
\text { RapeseedMustard } \\
\text { Safflower }\end{array}$} & -8.7 & -6.0 & 6.2 & -0.7 \\
\hline & -11.4 & 0.1 & 3.4 & -27.2 \\
\hline & & & 9.3 & 11.6 \\
\hline & & & -18.6 & -53.9 \\
\hline Sunflower & -14.6 & -40.2 & -47.4 & -65.5 \\
\hline Sesamum & -12.6 & -9.0 & -19.8 & -81.1 \\
\hline Linseed & & & 31.1 & 23.5 \\
\hline Other Oilseeds & & & -36.4 & 241.2 \\
\hline Soyabean & -7.7 & -4.0 & & \\
\hline Niger & 6.7 & -27.7 & & \\
\hline Caster & -2.6 & -30.7 & & \\
\hline \multirow{3}{*}{$\begin{array}{l}\text { Sugarcane } \\
\text { Jute and Mesta } \\
\text { Cotton }\end{array}$} & 9.4 & -0.2 & & \\
\hline & -6.5 & -15.6 & & \\
\hline & 18.7 & -0.6 & & \\
\hline \multicolumn{5}{|c|}{$\begin{array}{l}{ }^{1} \text { All India Crop Situation obtained from the website of the Department of Agriculture Cooperation and farmers welfare, } \\
\text { URL: http://agricoop.nic.in/all-india-crop-situation?page=1. } \\
2 \text { Missing data means the crop is not grown mainly in that season. }\end{array}$} \\
\hline
\end{tabular}


Table 7 Robustness Checks: Estimates for select commodities - export, procurement, commodity exchange based trade

This table presents difference in differences estimates for oilmeal and coffee exports, milk procurement in the state of Maharashtra by government, cooperatives and private dairy players, grain procurement by government. In addition, estimates for the value and quantity traded of specific commodities in the National Commodities and Derivatives Exchange (NCDEX).

\begin{tabular}{|c|c|c|c|c|}
\hline & Commodity & D-in-D estimates & Standard Error & Details \\
\hline \multirow[t]{5}{*}{1} & Total Oilmeal exports & 6726.52 & $(61759.54)$ & Monthly data, 2013-2017 \\
\hline & Soyameal & -4956.17 & $(59728.63)$ & (tonnes) \\
\hline & Rapeseed meal & 1469.74 & $(18793.42)$ & \\
\hline & Groundnut meal & -65.91 & $(151.14)$ & \\
\hline & Castormeal & -15763.46 & $(24495.68)$ & \\
\hline 2 & Total Coffee Exports & 3330.25 & $(3342.45)$ & $\begin{array}{l}\text { Monthly data, 2001-2017 } \\
\text { (tonnes) }\end{array}$ \\
\hline \multirow[t]{4}{*}{3} & $\begin{array}{l}\text { Total milk procurement (Maha- } \\
\text { rashtra) }\end{array}$ & $-40.85^{*}$ & $(16.81)$ & Monthly data, 2013-2016 \\
\hline & Government & 0.25 & $(0.91)$ & (in lakh litres per day) \\
\hline & Cooperatives & $-4.60^{*}$ & $(2.07)$ & \\
\hline & Private & $-35.51^{*}$ & $(14.88)$ & \\
\hline \multirow[t]{6}{*}{4} & Total grain procurement & -0.14 & $(0.07)$ & Monthly data, 2011-2017 \\
\hline & Rice Procurement & -0.17 & $(0.11)$ & $\begin{array}{l}\text { in log (procurement in ten } \\
\text { thousand tonnes) }\end{array}$ \\
\hline & Wheat procurement & -0.14 & $(0.09)$ & \\
\hline & Total grain procurement & -0.14 & $(0.07)$ & \\
\hline & Unmilled Paddy procurement & $0.61^{* *}$ & $(0.14)$ & \\
\hline & Coarse grain procurement & -0.5 & $(0.29)$ & \\
\hline \multirow[t]{5}{*}{$5 \mathrm{a}$} & NCDEX Quantity traded & & & Daily data $2013-17$ \\
\hline & Wheat & 0.080 & $(0.38)$ & $\log$ (traded qty. in tonnes) \\
\hline & Turmeric & $-1.504^{* *}$ & $(0.34)$ & \\
\hline & Soyabean & $-1.189^{*}$ & $(0.46)$ & \\
\hline & Cotton(Shankar/kapas) & -0.014 & $(0.05)$ & \\
\hline \multirow[t]{5}{*}{$5 \mathrm{~b}$} & NCDEX Value traded & & & Daily data $2013-17$ \\
\hline & Wheat & 0.170 & $(0.32)$ & $\log$ (value in lakhs) \\
\hline & Turmeric & $-1.548^{* *}$ & $(0.36)$ & \\
\hline & Soyabean & $-1.237^{* *}$ & $(0.44)$ & \\
\hline & Cotton(Shankar/kapas) & 0.007 & $(0.08)$ & \\
\hline \multicolumn{5}{|c|}{$\begin{array}{l}{ }^{1} \text { Coefficients and standard errors presented fo } \\
\text { demonetization. } \\
2 * * \text { refers to } 1 \% \text { level of significance, } * 5 \% \text { level o } \\
{ }^{3} \text { For milk procurement, the analysis is restricted } \\
{ }^{4} \text { The full results are available with the authors. }\end{array}$} \\
\hline
\end{tabular}




\section{Table 8 Impact of demonetization after one week}

The table below presents the coefficient estimates of $\alpha_{3}$ (value), $\beta_{3}$ (arrivals), and $\gamma_{3}$ based on commodity specific regressions specified in Equation 1-3. Minimum value represents traded value based on minimum prices reported in data, while maximum value indicates traded value based on maximum prices. The event window used in the regressions is 7 days after demonetization. Standard errors are robust to heteroscedasticity. The values that are boldfaced are significant at $5 \%$ level.

\begin{tabular}{|c|c|c|c|c|c|c|c|c|c|c|c|c|c|c|}
\hline \multirow[b]{2}{*}{ Commodity } & \multicolumn{3}{|c|}{ Minimum value } & \multicolumn{3}{|c|}{ Maximum value } & \multicolumn{3}{|c|}{ Minimum prices } & \multicolumn{3}{|c|}{ Arrivals } & \multirow[t]{2}{*}{ \# of obs. } & \multirow[t]{2}{*}{ Treated Obs. } \\
\hline & $\alpha_{3}$ & t-stat & $\mathrm{R}^{2}$ & $\alpha_{3}$ & t-stat & $\mathrm{R}^{2}$ & $\beta_{3}$ & t-stat & $\mathrm{R}^{2}$ & $\gamma_{3}$ & t-stat & $\mathrm{R}^{2}$ & & \\
\hline Paddy & 0.32 & 8.46 & 0.85 & 0.32 & 8.47 & 0.85 & -0.02 & -4.02 & 0.46 & 0.34 & 8.93 & 0.85 & 224,771 & 2,661 \\
\hline Jowar & -0.28 & -3.76 & 0.60 & -0.31 & -4.12 & 0.59 & 0.01 & 0.53 & 0.52 & -0.29 & -3.89 & 0.58 & 49,781 & 381 \\
\hline Bajra & -0.4 & -5.71 & 0.62 & -0.4 & -5.64 & 0.62 & -0.08 & -13.26 & 0.58 & -0.33 & -4.62 & 0.63 & 78,120 & 567 \\
\hline Maize & -0.02 & -0.44 & 0.69 & -0.04 & -0.80 & 0.68 & -0.04 & -9.88 & 0.54 & 0.02 & 0.40 & 0.68 & 108,697 & 1,329 \\
\hline Rice & -0.11 & -3.68 & 0.85 & -0.11 & -3.84 & 0.85 & 0 & 0.75 & 0.63 & -0.11 & -3.91 & 0.86 & 119,794 & 1,085 \\
\hline Ragi & -0.19 & -0.92 & 0.66 & -0.26 & -1.19 & 0.66 & 0.17 & 6.31 & 0.63 & -0.37 & -1.65 & 0.66 & 9,975 & 85 \\
\hline Wheat & -0.2 & -5.57 & 0.70 & -0.2 & -5.55 & 0.70 & 0.02 & 5.27 & 0.52 & -0.22 & -6.12 & 0.70 & 239,035 & 1,203 \\
\hline Cotton & 0.22 & 4.36 & 0.78 & 0.21 & 4.18 & 0.78 & 0.02 & 3.58 & 0.31 & 0.2 & 3.98 & 0.78 & 54,873 & 1,199 \\
\hline Bengal Gram & 0 & -0.06 & 0.74 & -0.01 & -0.27 & 0.74 & 0.14 & 13.46 & 0.77 & -0.15 & -2.82 & 0.73 & 84,420 & 502 \\
\hline Arhar & -0.27 & -3.67 & 0.69 & -0.26 & -3.42 & 0.69 & -0.15 & -8.48 & 0.75 & -0.13 & -1.76 & 0.66 & 46,421 & 355 \\
\hline Soyabean & -0.69 & -9.54 & 0.61 & -0.7 & -9.36 & 0.61 & -0.05 & -5.35 & 0.42 & -0.66 & -8.89 & 0.62 & 90,855 & 744 \\
\hline Mustard & -0.01 & -0.17 & 0.71 & -0.01 & -0.17 & 0.71 & -0.04 & -8.95 & 0.55 & 0.03 & 0.59 & 0.70 & 113,320 & 497 \\
\hline Groundnut & -0.34 & -3.66 & 0.60 & -0.4 & -4.27 & 0.60 & -0.05 & -3.44 & 0.61 & -0.3 & -3.24 & 0.61 & 50,509 & 371 \\
\hline Cumin & 0.31 & 1.42 & 0.64 & 0.36 & 1.60 & 0.65 & -0.12 & -3.76 & 0.64 & 0.44 & 2.00 & 0.65 & 16,545 & 29 \\
\hline Coriander seed & -0.82 & -6.38 & 0.72 & -0.87 & -6.58 & 0.74 & -0.13 & -3.51 & 0.55 & -0.71 & -5.57 & 0.75 & 18,864 & 74 \\
\hline Dry Chilli & -0.23 & -1.67 & 0.76 & -0.14 & -0.92 & 0.78 & -0.12 & -2.90 & 0.76 & -0.11 & -0.76 & 0.80 & 9,945 & 106 \\
\hline Turmeric & -0.42 & -2.72 & 0.77 & -0.47 & -3.03 & 0.77 & 0 & 0.09 & 0.65 & -0.43 & -2.73 & 0.78 & 11,212 & 102 \\
\hline Turmeric raw & 0.43 & 1.96 & 0.60 & 0.25 & 1.12 & 0.60 & 0.21 & 1.93 & 0.76 & 0.25 & 1.26 & 0.65 & 1,264 & 44 \\
\hline Arecanut & -0.25 & -2.60 & 0.73 & -0.24 & -2.57 & 0.75 & -0.08 & -2.36 & 0.65 & -0.17 & -1.90 & 0.76 & 18,487 & 247 \\
\hline Cashewnuts & -0.43 & -1.58 & 0.89 & -0.45 & -1.67 & 0.89 & -0.37 & -2.55 & 0.72 & -0.06 & -0.24 & 0.94 & 3,191 & 31 \\
\hline Copra & 0.05 & 0.50 & 0.79 & 0.07 & 0.70 & 0.79 & 0.09 & 2.75 & 0.44 & -0.04 & -0.39 & 0.80 & 9,712 & 146 \\
\hline Brinjal & -0.15 & -7.11 & 0.78 & -0.14 & -6.69 & 0.79 & -0.19 & -16.45 & 0.64 & 0.04 & 1.95 & 0.77 & 219,897 & 2,291 \\
\hline Cabbage & -0.14 & -4.79 & 0.76 & -0.13 & -4.52 & 0.77 & -0.11 & -8.83 & 0.68 & -0.03 & -1.12 & 0.80 & 118,182 & 1,495 \\
\hline Cauliflower & -0.23 & -9.37 & 0.72 & -0.22 & -9.14 & 0.73 & -0.14 & -10.68 & 0.65 & -0.1 & -4.11 & 0.74 & 136,010 & 1,977 \\
\hline Okra & -0.13 & -4.22 & 0.74 & -0.13 & -4.20 & 0.75 & -0.18 & -13.57 & 0.52 & 0.05 & 1.54 & 0.75 & 159,877 & 1,147 \\
\hline Onion & -0.13 & -5.90 & 0.78 & -0.14 & -6.47 & 0.80 & -0.03 & -3.42 & 0.65 & -0.1 & -4.97 & 0.82 & 251,968 & 2,421 \\
\hline Potato & -0.24 & -12.69 & 0.82 & -0.23 & -12.10 & 0.83 & -0.31 & -33.55 & 0.57 & 0.07 & 4.12 & 0.84 & 282,598 & 2,760 \\
\hline Tomato & -0.36 & -16.94 & 0.79 & -0.35 & -16.67 & 0.80 & -0.46 & -47.47 & 0.61 & 0.11 & 5.54 & 0.83 & 248,118 & 2,598 \\
\hline Apple & -0.27 & -7.20 & 0.74 & -0.28 & -7.21 & 0.75 & -0.12 & -9.08 & 0.71 & -0.17 & -4.27 & 0.75 & 104,515 & 966 \\
\hline Banana & 0.01 & 0.24 & 0.78 & 0.02 & 0.58 & 0.78 & -0.1 & -9.48 & 0.85 & 0.11 & 3.68 & 0.81 & 120,127 & 1,060 \\
\hline Guava & -0.16 & -2.06 & 0.71 & -0.08 & -0.96 & 0.71 & -0.22 & -5.71 & 0.69 & 0.07 & 0.86 & 0.69 & 22,821 & 217 \\
\hline Orange & -0.25 & -3.21 & 0.71 & -0.21 & -2.70 & 0.72 & -0.01 & -0.36 & 0.75 & -0.25 & -3.47 & 0.75 & 16,307 & 330 \\
\hline Lemon & -0.18 & -3.71 & 0.74 & -0.15 & -3.16 & 0.75 & -0.45 & -19.15 & 0.67 & 0.29 & 6.31 & 0.77 & 59,498 & 399 \\
\hline Lime & -0.27 & -2.39 & 0.77 & -0.2 & -1.86 & 0.79 & -0.41 & -5.29 & 0.83 & 0.16 & 1.95 & 0.84 & 13,209 & 121 \\
\hline Sweet Lime & -0.03 & -0.42 & 0.76 & -0.01 & -0.14 & 0.78 & -0.03 & -1.40 & 0.66 & 0 & 0.07 & 0.79 & 57,547 & 317 \\
\hline
\end{tabular}




\section{Table 9 Impact of demonetization after two weeks}

The table below presents the coefficient estimates of $\alpha_{3}$ (value), $\beta_{3}$ (arrivals), and $\gamma_{3}$ from commodity specific regressions specified in Equation 1-3. Minimum value represents traded value based on minimum prices reported in data, while maximum value indicates traded value based on maximum prices. The event window used in the regressions is 15 days after demonetization. Standard errors are robust to heteroscedasticity. The values that are boldfaced are significant at $5 \%$ level.

\begin{tabular}{|c|c|c|c|c|c|c|c|c|c|c|c|c|c|c|}
\hline \multirow[b]{2}{*}{ Commodity } & \multicolumn{3}{|c|}{ Minimum value } & \multicolumn{3}{|c|}{ Maximum value } & \multicolumn{3}{|c|}{ Minimum prices } & \multicolumn{3}{|c|}{ Arrivals } & \multirow[t]{2}{*}{ \# of obs. } & \multirow[t]{2}{*}{ Treated Obs. } \\
\hline & $\alpha_{3}$ & t-stat & $\mathrm{R}^{2}$ & $\alpha_{3}$ & t-stat & $\mathrm{R}^{2}$ & $\beta_{3}$ & t-stat & $\mathrm{R}^{2}$ & $\gamma_{3}$ & t-stat & $\mathrm{R}^{2}$ & & \\
\hline Paddy & 0.46 & 16.58 & 0.84 & 0.46 & 16.54 & 0.84 & -0.02 & -6.84 & 0.46 & 0.49 & 17.36 & 0.84 & 242,916 & 5,664 \\
\hline Jowar & -0.2 & -3.96 & 0.59 & -0.21 & -4.01 & 0.59 & 0.01 & 0.70 & 0.53 & -0.21 & -4.12 & 0.58 & 53,544 & 1,009 \\
\hline Bajra & -0.29 & -6.26 & 0.62 & -0.28 & -6.13 & 0.62 & -0.07 & -17.26 & 0.57 & -0.21 & -4.66 & 0.63 & 83,813 & 1,417 \\
\hline Maize & 0.05 & 1.30 & 0.68 & 0.03 & 0.88 & 0.68 & -0.05 & -16.09 & 0.52 & 0.1 & 2.68 & 0.68 & 118,092 & 3,111 \\
\hline Ragi & 0.22 & 1.51 & 0.66 & 0.19 & 1.27 & 0.65 & 0.15 & 6.87 & 0.63 & 0.07 & 0.48 & 0.66 & 10,492 & 164 \\
\hline Rice & -0.12 & -5.73 & 0.85 & -0.13 & -5.86 & 0.85 & 0 & -0.34 & 0.63 & -0.12 & -5.78 & 0.86 & 126,904 & 2,258 \\
\hline Wheat & -0.15 & -6.47 & 0.70 & -0.15 & -6.49 & 0.69 & 0.03 & 9.19 & 0.52 & -0.18 & -7.74 & 0.70 & 253,167 & 3,326 \\
\hline Cotton & 0.18 & 4.80 & 0.77 & 0.18 & 4.66 & 0.78 & 0.02 & 5.23 & 0.31 & 0.16 & 4.21 & 0.78 & 63,409 & 2,609 \\
\hline Bengal Gram & -0.14 & -3.61 & 0.74 & -0.13 & -3.35 & 0.74 & 0.08 & 11.67 & 0.76 & -0.23 & -6.11 & 0.73 & 88,979 & 1,276 \\
\hline Arhar & -0.27 & -5.56 & 0.69 & -0.26 & -5.18 & 0.68 & -0.18 & -15.31 & 0.74 & -0.1 & -2.05 & 0.66 & 48,906 & 905 \\
\hline Soyabean & -0.62 & -14.54 & 0.61 & -0.63 & -14.35 & 0.62 & -0.03 & -5.73 & 0.41 & -0.6 & -13.90 & 0.62 & 99,299 & 2,258 \\
\hline Mustard & -0.09 & -2.24 & 0.70 & -0.09 & -2.34 & 0.70 & -0.07 & -18.57 & 0.54 & -0.02 & -0.62 & 0.70 & 119,302 & 1,223 \\
\hline Groundnut & -0.09 & -1.51 & 0.61 & -0.17 & -2.63 & 0.61 & -0.03 & -3.58 & 0.61 & -0.06 & -0.99 & 0.62 & 54,731 & 884 \\
\hline Cumin & 0.24 & 1.45 & 0.64 & 0.29 & 1.73 & 0.65 & -0.13 & -4.80 & 0.64 & 0.38 & 2.29 & 0.65 & 17,489 & 74 \\
\hline Coriander seed & -0.8 & -9.07 & 0.72 & -0.83 & -9.24 & 0.74 & -0.16 & -6.89 & 0.55 & -0.66 & -7.57 & 0.75 & 20,082 & 235 \\
\hline Dry Chillies & -0.17 & -1.59 & 0.76 & -0.07 & -0.60 & 0.78 & -0.12 & -3.83 & 0.76 & -0.05 & -0.47 & 0.80 & 10,597 & 221 \\
\hline Turmeric & -0.42 & -3.81 & 0.77 & -0.46 & -4.14 & 0.77 & -0.02 & -0.87 & 0.65 & -0.41 & -3.67 & 0.78 & 11,862 & 214 \\
\hline Turmeric raw & 0.41 & 2.49 & 0.62 & 0.27 & 1.62 & 0.62 & 0.19 & 2.51 & 0.75 & 0.26 & 1.59 & 0.66 & 1,472 & 93 \\
\hline Arecanut & -0.3 & -4.30 & 0.73 & -0.28 & -4.08 & 0.75 & -0.07 & -2.85 & 0.65 & -0.23 & -3.51 & 0.76 & 19,648 & 509 \\
\hline Cashewnuts & -0.33 & -1.57 & 0.89 & -0.35 & -1.67 & 0.89 & -0.37 & -3.23 & 0.72 & 0.04 & 0.20 & 0.94 & 3,349 & 52 \\
\hline Copra & 0.07 & 0.79 & 0.79 & 0.08 & 0.94 & 0.79 & 0.08 & 3.47 & 0.44 & -0.02 & -0.25 & 0.79 & 10,361 & 287 \\
\hline Brinjal & -0.19 & -12.53 & 0.78 & -0.18 & -11.55 & 0.79 & -0.25 & -29.37 & 0.64 & 0.06 & 4.39 & 0.77 & 232,868 & 4,709 \\
\hline Cabbage & -0.18 & -8.82 & 0.76 & -0.17 & -8.19 & 0.76 & -0.15 & -16.23 & 0.68 & -0.04 & -1.82 & 0.79 & 127,144 & 3,171 \\
\hline Cauliflower & -0.32 & -17.45 & 0.72 & -0.3 & -16.20 & 0.73 & -0.29 & -27.84 & 0.65 & -0.04 & -1.93 & 0.74 & 147,983 & 4,150 \\
\hline Okra & -0.16 & -6.75 & 0.73 & -0.16 & -6.44 & 0.74 & -0.23 & -22.45 & 0.52 & 0.07 & 2.95 & 0.75 & 165,531 & 2,293 \\
\hline Onion & -0.11 & -6.62 & 0.77 & -0.12 & -7.06 & 0.80 & -0.01 & -1.06 & 0.65 & -0.11 & -6.96 & 0.82 & 267,312 & 5,143 \\
\hline Potato & -0.31 & -22.00 & 0.82 & -0.29 & -20.58 & 0.83 & -0.36 & -53.60 & 0.57 & 0.05 & 4.14 & 0.84 & 299,365 & 5,741 \\
\hline Tomato & -0.35 & -22.30 & 0.78 & -0.35 & -22.18 & 0.80 & -0.47 & -63.96 & 0.60 & 0.13 & 8.51 & 0.83 & 262,678 & 5,347 \\
\hline Apple & -0.34 & -11.66 & 0.74 & -0.34 & -11.19 & 0.75 & -0.12 & -11.61 & 0.70 & -0.24 & -8.07 & 0.75 & 111,143 & 1,950 \\
\hline Banana & -0.02 & -0.93 & 0.78 & -0.01 & -0.58 & 0.78 & -0.11 & -13.99 & 0.85 & 0.09 & 4.18 & 0.81 & 127,101 & 2,218 \\
\hline Guava & -0.15 & -2.53 & 0.71 & -0.07 & -1.09 & 0.71 & -0.2 & -7.45 & 0.69 & 0.06 & 1.03 & 0.69 & 24,894 & 499 \\
\hline Orange & -0.27 & -4.45 & 0.71 & -0.23 & -3.70 & 0.72 & 0.01 & 0.55 & 0.75 & -0.3 & -5.05 & 0.75 & 19,338 & 698 \\
\hline Lemon & -0.24 & -7.02 & 0.74 & -0.22 & -6.25 & 0.75 & -0.48 & -28.59 & 0.67 & 0.25 & 7.43 & 0.77 & 62,449 & 826 \\
\hline Lime & -0.2 & -2.28 & 0.76 & -0.19 & -2.16 & 0.79 & -0.35 & -5.97 & 0.83 & 0.18 & 2.75 & 0.84 & 13,892 & 234 \\
\hline Sweet Lime & -0.04 & -0.79 & 0.76 & -0.02 & -0.39 & 0.78 & -0.06 & -3.41 & 0.65 & 0.02 & 0.38 & 0.78 & 60,340 & 629 \\
\hline
\end{tabular}


Table 10 Impact of demonetization after four weeks

The table below presents the coefficient estimates of $\alpha_{3}$ (value), $\beta_{3}$ (arrivals), and $\gamma_{3}$ based on commodity specific regressions specified in Equation 1-3. Minimum value represents traded value based on minimum prices reported in data, while maximum value indicates traded value based on maximum prices. The event window used in the regressions is 30 days after demonetization. Standard errors are robust to heteroscedasticity. The values that are boldfaced are significant at $5 \%$ level.

\begin{tabular}{|c|c|c|c|c|c|c|c|c|c|c|c|c|c|c|}
\hline \multirow[b]{2}{*}{ Commodity } & \multicolumn{3}{|c|}{ Minimum value } & \multicolumn{3}{|c|}{ Maximum value } & \multicolumn{3}{|c|}{ Minimum prices } & \multicolumn{3}{|c|}{ Arrivals } & \multirow{2}{*}{ \# of obs. } & \multirow[t]{2}{*}{ Treated Obs. } \\
\hline & $\alpha_{3}$ & t-stat & $\mathrm{R}^{2}$ & $\alpha_{3}$ & t-stat & $\mathrm{R}^{2}$ & $\beta_{3}$ & t-stat & $\mathrm{R}^{2}$ & $\gamma_{3}$ & t-stat & $\mathrm{R}^{2}$ & & \\
\hline Paddy & 0.42 & 24.87 & 0.82 & 0.43 & 25.30 & 0.82 & -0.03 & -18.23 & 0.47 & 0.46 & 27.03 & 0.82 & 306,888 & 16,801 \\
\hline Jowar & -0.25 & -8.54 & 0.58 & -0.25 & -8.05 & 0.58 & 0 & -0.75 & 0.52 & -0.25 & -8.51 & 0.57 & 67,627 & 3,844 \\
\hline Bajra & -0.24 & -9.57 & 0.63 & -0.23 & -8.91 & 0.62 & -0.1 & -37.37 & 0.52 & -0.14 & -5.50 & 0.63 & 104,486 & 5,268 \\
\hline Maize & 0.13 & 5.79 & 0.67 & 0.12 & 5.28 & 0.67 & -0.07 & -32.89 & 0.48 & 0.2 & 8.88 & 0.67 & 151,658 & 10,048 \\
\hline Rice & -0.15 & -11.08 & 0.85 & -0.15 & -11.48 & 0.85 & 0 & -0.23 & 0.63 & -0.15 & -11.31 & 0.86 & 153,164 & 6,420 \\
\hline Ragi & 0.43 & 4.78 & 0.66 & 0.39 & 4.21 & 0.66 & 0.11 & 7.29 & 0.62 & 0.33 & 3.59 & 0.66 & 12,462 & 516 \\
\hline Wheat & 0.03 & 2.42 & 0.70 & 0.03 & 2.55 & 0.69 & 0.03 & 20.19 & 0.48 & 0 & -0.06 & 0.70 & 305,150 & 12,568 \\
\hline Cotton & 0.24 & 9.37 & 0.77 & 0.23 & 9.15 & 0.77 & 0.01 & 2.54 & 0.33 & 0.23 & 9.09 & 0.77 & 97,353 & 8,971 \\
\hline Bengal Gram & -0.09 & -4.10 & 0.74 & -0.07 & -3.30 & 0.74 & 0.04 & 9.15 & 0.76 & -0.14 & -6.11 & 0.72 & 105,545 & 4,405 \\
\hline Arhar & -0.35 & -11.10 & 0.66 & -0.33 & -10.18 & 0.66 & -0.35 & -48.04 & 0.68 & 0 & -0.00 & 0.64 & 60,405 & 3,615 \\
\hline Soyabean & -0.16 & -6.86 & 0.62 & -0.17 & -7.25 & 0.63 & -0.06 & -20.46 & 0.36 & -0.11 & -4.41 & 0.63 & 128,966 & 8,841 \\
\hline Mustard & 0.08 & 3.94 & 0.70 & 0.08 & 3.80 & 0.70 & -0.1 & -48.11 & 0.49 & 0.19 & 8.75 & 0.69 & 141,774 & 4,747 \\
\hline Groundnut & 0.33 & 9.29 & 0.63 & 0.27 & 7.47 & 0.63 & -0.02 & -3.05 & 0.59 & 0.35 & 9.89 & 0.64 & 69,784 & 3,237 \\
\hline Cumin & 0.19 & 2.42 & 0.65 & 0.18 & 2.31 & 0.65 & 0 & -0.42 & 0.62 & 0.2 & 2.50 & 0.65 & 21,200 & 508 \\
\hline Coriander seed & -0.17 & -3.49 & 0.72 & -0.19 & -3.85 & 0.74 & -0.12 & -10.30 & 0.52 & -0.05 & -0.99 & 0.74 & 24,694 & 1,255 \\
\hline Dry Chilli & -0.04 & -0.59 & 0.75 & 0.08 & 1.03 & 0.77 & -0.16 & -7.69 & 0.75 & 0.11 & 1.51 & 0.80 & 13,042 & 653 \\
\hline Turmeric & -0.26 & -3.54 & 0.77 & -0.29 & -3.96 & 0.78 & 0.01 & 1.02 & 0.63 & -0.28 & -3.78 & 0.79 & 14,274 & 638 \\
\hline Turmeric raw & 0.08 & 0.55 & 0.61 & 0.02 & 0.17 & 0.61 & -0.09 & -1.54 & 0.74 & 0.19 & 1.31 & 0.63 & 2,239 & 246 \\
\hline Arecanut & -0.31 & -6.46 & 0.73 & -0.28 & -5.87 & 0.75 & -0.04 & -1.83 & 0.65 & -0.28 & -6.25 & 0.76 & 23,874 & 1,491 \\
\hline Cashewnuts & -0.01 & -0.09 & 0.88 & -0.05 & -0.37 & 0.89 & -0.21 & -2.77 & 0.70 & 0.21 & 1.67 & 0.93 & 3,890 & 147 \\
\hline Copra & 0.33 & 4.73 & 0.79 & 0.33 & 4.73 & 0.79 & 0.21 & 11.37 & 0.43 & 0.13 & 1.86 & 0.79 & 12,676 & 800 \\
\hline Brinjal & -0.21 & -21.07 & 0.78 & -0.18 & -18.60 & 0.78 & -0.3 & -55.21 & 0.64 & 0.1 & 10.81 & 0.77 & 278,169 & 13,050 \\
\hline Cabbage & -0.2 & -15.16 & 0.75 & -0.17 & -13.37 & 0.76 & -0.17 & -27.89 & 0.67 & -0.03 & -2.05 & 0.78 & 161,380 & 9,314 \\
\hline Cauliflower & -0.34 & -29.69 & 0.73 & -0.32 & -28.17 & 0.74 & -0.23 & -35.49 & 0.67 & -0.13 & -11.24 & 0.74 & 192,847 & 12,120 \\
\hline Okra & -0.16 & -9.84 & 0.73 & -0.15 & -9.20 & 0.73 & -0.21 & -29.75 & 0.53 & 0.05 & 3.30 & 0.73 & 183,271 & 5,851 \\
\hline Onion & -0.02 & -1.93 & 0.77 & -0.02 & -1.45 & 0.80 & 0.1 & 22.12 & 0.65 & -0.13 & -13.02 & 0.82 & 324,675 & 14,785 \\
\hline OnionGreen & 0.15 & 2.61 & 0.78 & 0.1 & 1.77 & 0.78 & 0.07 & 2.51 & 0.89 & 0.08 & 1.48 & 0.82 & 11,693 & 788 \\
\hline Potato & -0.44 & -49.01 & 0.82 & -0.39 & -43.76 & 0.82 & -0.47 & -107.67 & 0.55 & 0.03 & 3.10 & 0.84 & 362,356 & 16,470 \\
\hline Tomato & -0.34 & -33.74 & 0.78 & -0.33 & -33.08 & 0.80 & -0.44 & -89.61 & 0.59 & 0.11 & 11.75 & 0.82 & 317,822 & 15,135 \\
\hline Apple & -0.38 & -20.10 & 0.74 & -0.39 & -19.89 & 0.75 & -0.07 & -9.68 & 0.69 & -0.35 & -17.90 & 0.75 & 134,042 & 5,242 \\
\hline Banana & -0.05 & -3.34 & 0.78 & -0.04 & -2.54 & 0.78 & -0.11 & -21.08 & 0.84 & 0.06 & 4.15 & 0.80 & 151,643 & 6,069 \\
\hline Guava & -0.14 & -3.76 & 0.71 & -0.08 & -2.03 & 0.72 & -0.1 & -5.78 & 0.66 & -0.05 & -1.23 & 0.70 & 34,224 & 1,666 \\
\hline Orange & -0.21 & -5.35 & 0.71 & -0.2 & -4.85 & 0.73 & 0.13 & 5.51 & 0.73 & -0.37 & -9.17 & 0.74 & 30,689 & 2,173 \\
\hline Lemon & -0.25 & -10.94 & 0.73 & -0.21 & -9.46 & 0.75 & -0.58 & -51.24 & 0.66 & 0.35 & 16.47 & 0.77 & 72,803 & 2,363 \\
\hline Lime & -0.05 & -0.84 & 0.75 & -0.06 & -1.08 & 0.78 & -0.31 & -7.29 & 0.83 & 0.3 & 7.44 & 0.83 & 16,315 & 602 \\
\hline Sweet Lime & 0.06 & 1.82 & 0.76 & 0.08 & 2.60 & 0.77 & -0.06 & -5.22 & 0.64 & 0.12 & 3.64 & 0.78 & 68,962 & 1,449 \\
\hline
\end{tabular}


Table 11 Impact of demonetization after six weeks

The table below presents the coefficient estimates of $\alpha_{3}$ (value), $\beta_{3}$ (arrivals), and $\gamma_{3}$ from commodity specific regressions specified in Equation 1-3. Minimum value represents traded value based on minimum prices reported in data, while maximum value indicates traded value based on maximum prices. The event window used in the regressions is 45 days after demonetization. Standard errors are robust to heteroscedasticity. The values that are boldfaced are significant at $5 \%$ level.

\begin{tabular}{|c|c|c|c|c|c|c|c|c|c|c|c|c|c|c|}
\hline \multirow[b]{2}{*}{ Commodity } & \multicolumn{3}{|c|}{ Minimum value } & \multicolumn{3}{|c|}{ Maximum value } & \multicolumn{3}{|c|}{ Minimum prices } & \multicolumn{3}{|c|}{ Arrivals } & \multirow[t]{2}{*}{ \# of obs. } & \multirow[t]{2}{*}{ Treated Obs. } \\
\hline & $\alpha_{3}$ & t-stat & $\mathrm{R}^{2}$ & $\alpha_{3}$ & t-stat & $\mathrm{R}^{2}$ & $\beta_{3}$ & t-stat & $\mathrm{R}^{2}$ & $\gamma_{3}$ & t-stat & $\mathrm{R}^{2}$ & & \\
\hline Paddy & 0.47 & 23.07 & 0.83 & 0.47 & 23.24 & 0.83 & -0.03 & -13.87 & 0.47 & 0.5 & 24.72 & 0.83 & 274,735 & 11,233 \\
\hline Jowar & -0.22 & -6.46 & 0.58 & -0.22 & -6.15 & 0.58 & 0 & 0.79 & 0.52 & -0.23 & -6.66 & 0.58 & 60,619 & 2,435 \\
\hline Bajra & -0.23 & -7.65 & 0.62 & -0.22 & -7.12 & 0.62 & -0.09 & -28.33 & 0.54 & -0.14 & -4.52 & 0.63 & 94,316 & 3.352 \\
\hline Maize & 0.13 & 4.92 & 0.67 & 0.12 & 4.51 & 0.67 & -0.07 & -28.54 & 0.50 & 0.2 & 7.52 & 0.67 & 135,027 & 6,675 \\
\hline Rice & -0.15 & -9.81 & 0.85 & -0.16 & -10.12 & 0.85 & 0 & 0.48 & 0.63 & -0.15 & -10.14 & 0.86 & 140,159 & 4,393 \\
\hline Ragi & 0.39 & 3.79 & 0.66 & 0.36 & 3.34 & 0.66 & 0.12 & 7.23 & 0.62 & 0.28 & 2.61 & 0.66 & 11,423 & 314 \\
\hline Wheat & 0 & 0.27 & 0.69 & 0.01 & 0.40 & 0.69 & 0.03 & 18.65 & 0.50 & -0.03 & -2.08 & 0.70 & 279,408 & 8,026 \\
\hline Cotton & 0.22 & 7.96 & 0.77 & 0.22 & 7.84 & 0.77 & 0.02 & 4.99 & 0.32 & 0.21 & 7.40 & 0.77 & 80,034 & 5,747 \\
\hline Bengal Gram & -0.11 & -4.24 & 0.74 & -0.09 & -3.56 & 0.74 & 0.04 & 7.84 & 0.76 & -0.16 & -6.12 & 0.73 & 97,330 & 2,876 \\
\hline Arhar & -0.26 & -6.99 & 0.68 & -0.24 & -6.36 & 0.67 & -0.27 & -31.20 & 0.71 & 0.01 & 0.27 & 0.65 & 53,947 & 2,103 \\
\hline Soyabean & -0.23 & -8.55 & 0.62 & -0.24 & -8.71 & 0.62 & -0.04 & -13.04 & 0.38 & -0.19 & -7.00 & 0.63 & 114,390 & 5,639 \\
\hline Mustard & 0.06 & 2.20 & 0.70 & 0.05 & 2.06 & 0.70 & -0.08 & -34.31 & 0.52 & 0.14 & 5.50 & 0.69 & 130,517 & 2,934 \\
\hline Groundnut & 0.22 & 5.14 & 0.62 & 0.15 & 3.53 & 0.62 & -0.02 & -3.50 & 0.60 & 0.24 & 5.75 & 0.63 & 62,379 & 2,079 \\
\hline Cumin & 0.31 & 3.11 & 0.64 & 0.31 & 3.16 & 0.65 & -0.03 & -2.04 & 0.63 & 0.34 & 3.45 & 0.65 & 19,318 & 264 \\
\hline Coriander seed & -0.27 & -4.69 & 0.72 & -0.29 & -4.93 & 0.74 & -0.13 & -9.69 & 0.53 & -0.14 & -2.50 & 0.74 & 22,396 & 734 \\
\hline Dry Chilli & -0.1 & -1.19 & 0.75 & 0 & -0.02 & 0.78 & -0.12 & -5.03 & 0.75 & 0.02 & 0.21 & 0.80 & 11,808 & 449 \\
\hline Turmeric & -0.29 & -3.44 & 0.77 & -0.32 & -3.84 & 0.77 & 0 & 0.06 & 0.64 & -0.29 & -3.48 & 0.78 & 13,069 & 425 \\
\hline Turmeric raw & 0.32 & 2.15 & 0.61 & 0.25 & 1.66 & 0.61 & 0.04 & 0.62 & 0.73 & 0.31 & 2.08 & 0.63 & 1,859 & 172 \\
\hline Arecanut & -0.29 & -5.48 & 0.73 & -0.26 & -5.03 & 0.75 & -0.05 & -2.15 & 0.65 & -0.25 & -5.06 & 0.76 & 21,753 & 1,009 \\
\hline Cashewnuts & -0.11 & -0.71 & 0.88 & -0.15 & -0.93 & 0.89 & -0.27 & -3.06 & 0.70 & 0.16 & 1.13 & 0.93 & 3,620 & 100 \\
\hline Copra & 0.26 & 3.56 & 0.79 & 0.26 & 3.63 & 0.79 & 0.16 & 8.50 & 0.44 & 0.1 & 1.38 & 0.79 & 11,494 & 540 \\
\hline Brinjal & -0.22 & -18.76 & 0.78 & -0.19 & -16.74 & 0.78 & -0.29 & -45.20 & 0.64 & 0.08 & 7.53 & 0.77 & 255,963 & 8,947 \\
\hline Cabbage & -0.19 & -12.80 & 0.75 & -0.17 & -11.49 & 0.76 & -0.15 & -22.16 & 0.68 & -0.04 & -2.86 & 0.79 & 143,979 & 6,227 \\
\hline Cauliflower & -0.36 & -27.17 & 0.72 & -0.34 & -25.94 & 0.74 & -0.27 & -34.69 & 0.66 & -0.11 & -8.38 & 0.74 & 170,193 & 8,119 \\
\hline Okra & -0.16 & -8.85 & 0.73 & -0.16 & -8.47 & 0.74 & -0.22 & -27.43 & 0.53 & 0.06 & 3.21 & 0.74 & 174,682 & 4,172 \\
\hline Onion & -0.08 & -6.99 & 0.77 & -0.08 & -6.40 & 0.80 & 0.04 & 6.83 & 0.65 & -0.13 & -11.38 & 0.82 & 295,777 & 9,953 \\
\hline Potato & -0.41 & -38.59 & 0.82 & -0.36 & -35.10 & 0.82 & -0.43 & -85.04 & 0.55 & 0.02 & 2.23 & 0.84 & 330,578 & 11,101 \\
\hline Tomato & -0.34 & -28.82 & 0.78 & -0.33 & -28.69 & 0.80 & -0.44 & -79.97 & 0.60 & 0.12 & 10.48 & 0.82 & 289,781 & 10,238 \\
\hline Apple & -0.4 & -18.07 & 0.74 & -0.4 & -17.74 & 0.75 & -0.09 & -11.35 & 0.70 & -0.33 & -15.00 & 0.75 & 122,663 & 3,595 \\
\hline Banana & -0.04 & -2.55 & 0.78 & -0.03 & -1.93 & 0.78 & -0.11 & -19.13 & 0.84 & 0.07 & 4.32 & 0.81 & 139,474 & 4,177 \\
\hline Guava & -0.12 & -2.86 & 0.71 & -0.05 & -1.21 & 0.71 & -0.14 & -7.14 & 0.67 & 0.02 & 0.51 & 0.69 & 29,329 & 1,074 \\
\hline Orange & -0.22 & -4.92 & 0.71 & -0.2 & -4.33 & 0.72 & 0.09 & 4.04 & 0.75 & -0.33 & -7.62 & 0.75 & 25,056 & 1,453 \\
\hline Lemon & -0.24 & -9.12 & 0.74 & -0.21 & -8.02 & 0.75 & -0.53 & -40.79 & 0.66 & 0.31 & 12.40 & 0.77 & 67,739 & 1,577 \\
\hline Lime & -0.11 & -1.67 & 0.76 & -0.13 & -1.96 & 0.78 & -0.31 & -6.77 & 0.83 & 0.24 & 5.00 & 0.83 & 15,133 & 424 \\
\hline Sweet Lime & 0.02 & 0.48 & 0.76 & 0.04 & 1.09 & 0.78 & -0.05 & -4.45 & 0.65 & 0.08 & 1.99 & 0.78 & 64,832 & 1,069 \\
\hline
\end{tabular}


Table 12 Impact of demonetization after eight weeks

The table below presents the coefficient estimates of $\alpha_{3}$ (value), $\beta_{3}$ (arrivals), and $\gamma_{3}$ from commodity specific regressions specified in Equation 1-3. Minimum value represents traded value based on minimum prices reported in data, while maximum value indicates traded value based on maximum prices. The event window used in the regressions is 60 days after demonetization. Standard errors are robust to heteroscedasticity. The values that are boldfaced are significant at $5 \%$ level.

\begin{tabular}{|c|c|c|c|c|c|c|c|c|c|c|c|c|c|c|}
\hline \multirow[b]{2}{*}{ Commodity } & \multicolumn{3}{|c|}{ Minimum value } & \multicolumn{3}{|c|}{ Maximum value } & \multicolumn{3}{|c|}{ Minimum prices } & \multicolumn{3}{|c|}{ Arrivals } & \multirow[t]{2}{*}{ \# of obs. } & \multirow[t]{2}{*}{ Treated Obs } \\
\hline & $\alpha_{3}$ & t-stat & $\mathrm{R}^{2}$ & $\alpha_{3}$ & t-stat & $\mathrm{R}^{2}$ & $\beta_{3}$ & t-stat & $\mathrm{R}^{2}$ & $\gamma_{3}$ & t-stat & $\mathrm{R}^{2}$ & & \\
\hline Paddy & 0.39 & 25.43 & 0.81 & 0.4 & 26.07 & 0.82 & -0.03 & -18.01 & 0.47 & 0.42 & 27.56 & 0.81 & 335,927 & 21,586 \\
\hline Jowar & -0.28 & -10.63 & 0.57 & -0.27 & -9.90 & 0.57 & -0.02 & -5.51 & 0.51 & -0.26 & -9.79 & 0.57 & 74,130 & 4,991 \\
\hline Bajra & -0.23 & -10.42 & 0.63 & -0.22 & -9.72 & 0.62 & -0.11 & -44.38 & 0.50 & -0.13 & -5.55 & 0.63 & 113,912 & 6,784 \\
\hline Maize & 0.1 & 4.86 & 0.67 & 0.09 & 4.36 & 0.67 & -0.07 & -36.84 & 0.47 & 0.17 & 8.37 & 0.67 & 166,683 & 12,777 \\
\hline Rice & -0.14 & -11.41 & 0.85 & -0.14 & -11.94 & 0.85 & 0.01 & 1.97 & 0.62 & -0.14 & -12.15 & 0.86 & 165,412 & 8,123 \\
\hline Ragi & 0.31 & 3.94 & 0.66 & 0.26 & 3.24 & 0.66 & 0.12 & 9.09 & 0.61 & 0.19 & 2.40 & 0.66 & 13,527 & 718 \\
\hline Wheat & 0.03 & 2.78 & 0.69 & 0.03 & 3.03 & 0.69 & 0.02 & 17.27 & 0.46 & 0.01 & 0.71 & 0.70 & 328,945 & 16,322 \\
\hline Cotton & 0.24 & 9.99 & 0.77 & 0.23 & 9.72 & 0.77 & 0.01 & 2.91 & 0.34 & 0.23 & 9.67 & 0.76 & 113,334 & 11,651 \\
\hline Bengal Gram & -0.11 & -5.18 & 0.73 & -0.09 & -4.33 & 0.73 & 0.02 & 5.65 & 0.76 & -0.14 & -6.51 & 0.72 & 113,661 & 5,598 \\
\hline Arhar & -0.41 & -14.98 & 0.65 & -0.39 & -13.86 & 0.64 & -0.43 & -67.76 & 0.65 & 0.02 & 0.63 & 0.62 & 68,869 & 5,429 \\
\hline Soyabean & -0.03 & -1.66 & 0.63 & -0.05 & -2.35 & 0.63 & -0.06 & -25.46 & 0.34 & 0.03 & 1.39 & 0.63 & 141,973 & 11,553 \\
\hline Mustard & 0.08 & 4.24 & 0.70 & 0.08 & 4.13 & 0.69 & -0.11 & -57.05 & 0.48 & 0.19 & 10.02 & 0.69 & 152,110 & 6,153 \\
\hline Groundnut & 0.4 & 12.48 & 0.63 & 0.35 & 10.59 & 0.64 & -0.02 & -3.85 & 0.58 & 0.43 & 13.22 & 0.64 & 76,546 & 4,284 \\
\hline Cumin & 0.17 & 2.63 & 0.64 & 0.16 & 2.37 & 0.65 & -0.01 & -1.28 & 0.61 & 0.19 & 2.84 & 0.65 & 22,997 & 740 \\
\hline Coriander seed & -0.04 & -1.01 & 0.71 & -0.06 & -1.44 & 0.73 & -0.12 & -11.06 & 0.50 & 0.07 & 1.72 & 0.74 & 26,826 & 1,691 \\
\hline Dry Chilli & -0.05 & -0.74 & 0.75 & 0.08 & 1.07 & 0.77 & -0.17 & -8.99 & 0.73 & 0.11 & 1.68 & 0.79 & 14,226 & 848 \\
\hline Turmeric & -0.23 & -3.43 & 0.77 & -0.26 & -3.97 & 0.78 & 0.02 & 1.66 & 0.62 & -0.25 & -3.79 & 0.79 & 15,436 & 835 \\
\hline Turmeric raw & 0.03 & 0.23 & 0.59 & -0.03 & -0.22 & 0.59 & -0.14 & -2.36 & 0.75 & 0.18 & 1.27 & 0.60 & 2,605 & 308 \\
\hline Arecanut & -0.35 & -7.97 & 0.73 & -0.32 & -7.39 & 0.75 & -0.04 & -2.26 & 0.65 & -0.32 & -7.68 & 0.75 & 26,093 & 1,954 \\
\hline Cashewnuts & 0.2 & 1.43 & 0.87 & 0.16 & 1.15 & 0.88 & -0.12 & -1.68 & 0.69 & 0.33 & 2.56 & 0.92 & 4,142 & 192 \\
\hline Copra & 0.31 & 4.85 & 0.79 & 0.31 & 4.84 & 0.78 & 0.23 & 13.56 & 0.43 & 0.09 & 1.37 & 0.78 & 13,783 & 1,046 \\
\hline Brinjal & -0.2 & -22.03 & 0.77 & -0.17 & -18.94 & 0.78 & -0.31 & -62.40 & 0.64 & 0.12 & 13.76 & 0.76 & 297,833 & 16,398 \\
\hline Cabbage & -0.21 & -17.84 & 0.75 & -0.18 & -15.55 & 0.76 & -0.19 & -32.97 & 0.67 & -0.02 & -1.72 & 0.78 & 177,780 & 12,043 \\
\hline Cauliflower & -0.38 & -36.00 & 0.73 & -0.35 & -33.52 & 0.74 & -0.29 & -48.39 & 0.67 & -0.11 & -10.15 & 0.74 & 213,805 & 15,471 \\
\hline Okra & -0.1 & -6.90 & 0.72 & -0.09 & -6.16 & 0.73 & -0.18 & -27.14 & 0.53 & 0.08 & 5.80 & 0.73 & 191,154 & 7,272 \\
\hline Onion & 0.05 & 4.99 & 0.77 & 0.05 & 5.00 & 0.80 & 0.16 & 38.58 & 0.65 & -0.12 & -12.95 & 0.82 & 351,540 & 18,873 \\
\hline Potato & -0.47 & -56.88 & 0.81 & -0.41 & -50.34 & 0.82 & -0.48 & -123.48 & 0.55 & 0.01 & 1.76 & 0.84 & 391,478 & 20,855 \\
\hline Tomato & -0.34 & -36.54 & 0.78 & -0.33 & -35.40 & 0.79 & -0.44 & -93.90 & 0.59 & 0.11 & 12.09 & 0.82 & 343,696 & 19,259 \\
\hline Apple & -0.36 & -20.16 & 0.73 & -0.36 & -19.65 & 0.74 & -0.05 & -8.26 & 0.69 & -0.33 & -18.49 & 0.74 & 143,755 & 6,447 \\
\hline Banana & -0.03 & -2.17 & 0.78 & -0.02 & -1.34 & 0.78 & -0.1 & -21.01 & 0.84 & 0.07 & 5.45 & 0.80 & 162,205 & 7,605 \\
\hline Guava & -0.05 & -1.31 & 0.71 & 0.01 & 0.41 & 0.72 & -0.05 & -3.30 & 0.65 & 0.01 & 0.23 & 0.71 & 38,575 & 2,129 \\
\hline Orange & -0.22 & -5.74 & 0.71 & -0.2 & -5.10 & 0.72 & 0.12 & 5.66 & 0.71 & -0.38 & -9.71 & 0.73 & 35,011 & 2,672 \\
\hline Lemon & -0.26 & -12.59 & 0.73 & -0.22 & -10.98 & 0.74 & -0.61 & -59.07 & 0.66 & 0.38 & 19.53 & 0.77 & 77,250 & 2,978 \\
\hline Lime & -0.03 & -0.62 & 0.75 & -0.04 & -0.82 & 0.78 & -0.31 & -8.03 & 0.83 & 0.33 & 8.87 & 0.83 & 17,500 & 767 \\
\hline Sweet Lime & 0.11 & 3.94 & 0.75 & 0.14 & 4.80 & 0.77 & -0.05 & -5.25 & 0.63 & 0.18 & 5.83 & 0.77 & 72,168 & 1,728 \\
\hline
\end{tabular}


Table 13 Impact of demonetization after ten weeks

The table below presents the coefficient estimates of $\alpha_{3}$ (value), $\beta_{3}$ (arrivals), and $\gamma_{3}$ from commodity specific regressions specified in Equation 1-3. Minimum value represents traded value based on minimum prices reported in data, while maximum value indicates traded value based on maximum prices. The event window used in the regressions is 75 days after demonetization. Standard errors are robust to heteroscedasticity. The values that are boldfaced are significant at $5 \%$ level.

\begin{tabular}{|c|c|c|c|c|c|c|c|c|c|c|c|c|c|c|}
\hline \multirow[b]{2}{*}{ Commodity } & \multicolumn{3}{|c|}{ Minimum value } & \multicolumn{3}{|c|}{ Maximum value } & \multicolumn{3}{|c|}{ Minimum prices } & \multicolumn{3}{|c|}{ Arrivals } & \multirow[t]{2}{*}{ \# of obs. } & \multirow[t]{2}{*}{ Treated Obs } \\
\hline & $\alpha_{3}$ & t-stat & $\mathrm{R}^{2}$ & $\alpha_{3}$ & t-stat & $\mathrm{R}^{2}$ & $\beta_{3}$ & t-stat & $\mathrm{R}^{2}$ & $\gamma_{3}$ & t-stat & $\mathrm{R}^{2}$ & & \\
\hline Paddy & 0.38 & 26.68 & 0.81 & 0.39 & 27.49 & 0.81 & -0.02 & -15.35 & 0.47 & 0.4 & 28.53 & 0.81 & 365,081 & 26,420 \\
\hline Jowar & -0.25 & -10.10 & 0.57 & -0.23 & -9.24 & 0.57 & -0.03 & -7.06 & 0.51 & -0.22 & -8.98 & 0.56 & 80,670 & 6,220 \\
\hline Bajra & -0.21 & -10.23 & 0.63 & -0.2 & -9.51 & 0.62 & -0.11 & -47.75 & 0.48 & -0.1 & -4.96 & 0.63 & 123,243 & 8,487 \\
\hline Maize & 0.09 & 4.82 & 0.67 & 0.08 & 4.32 & 0.67 & -0.07 & -39.63 & 0.46 & 0.17 & 8.64 & 0.67 & 181,810 & 15,725 \\
\hline Rice & -0.13 & -11.60 & 0.84 & -0.14 & -12.21 & 0.85 & 0.01 & 4.18 & 0.62 & -0.14 & -12.83 & 0.86 & 178,832 & 10,161 \\
\hline Ragi & 0.25 & 3.42 & 0.66 & 0.19 & 2.55 & 0.66 & 0.13 & 10.55 & 0.60 & 0.12 & 1.68 & 0.66 & 14,538 & 876 \\
\hline Wheat & 0.05 & 4.48 & 0.69 & 0.05 & 4.81 & 0.69 & 0.02 & 19.63 & 0.45 & 0.02 & 2.17 & 0.70 & 354,173 & 20,821 \\
\hline Cotton & 0.25 & 11.01 & 0.76 & 0.25 & 10.75 & 0.76 & 0.01 & 3.88 & 0.36 & 0.24 & 10.57 & 0.76 & 129,581 & 14,462 \\
\hline Bengal Gram & -0.14 & -7.17 & 0.72 & -0.12 & -6.19 & 0.72 & 0 & -1.02 & 0.75 & -0.14 & -7.25 & 0.71 & 122,959 & 6,963 \\
\hline Arhar & -0.42 & -17.11 & 0.64 & -0.39 & -15.57 & 0.63 & -0.48 & -85.34 & 0.63 & 0.06 & 2.27 & 0.61 & 79,382 & 7,745 \\
\hline Soyabean & 0.09 & 4.40 & 0.62 & 0.07 & 3.46 & 0.63 & -0.06 & -27.62 & 0.33 & 0.15 & 7.73 & 0.63 & 155,632 & 14,635 \\
\hline Mustard & 0.12 & 6.88 & 0.69 & 0.12 & 6.86 & 0.69 & -0.11 & -63.00 & 0.46 & 0.23 & 13.43 & 0.68 & 163,165 & 8,038 \\
\hline Groundnut & 0.45 & 14.83 & 0.63 & 0.4 & 12.92 & 0.63 & -0.02 & -4.09 & 0.58 & 0.48 & 15.58 & 0.63 & 83,183 & 5,368 \\
\hline Cumin & 0.24 & 4.07 & 0.64 & 0.22 & 3.75 & 0.65 & -0.01 & -0.99 & 0.60 & 0.25 & 4.25 & 0.65 & 24,666 & 1,005 \\
\hline Coriander seed & 0.04 & 0.95 & 0.71 & 0.02 & 0.49 & 0.73 & -0.1 & -10.73 & 0.49 & 0.15 & 3.70 & 0.73 & 29,081 & 2,159 \\
\hline Dry Chilli & -0.15 & -2.37 & 0.74 & -0.02 & -0.36 & 0.76 & -0.17 & -9.86 & 0.73 & 0.02 & 0.31 & 0.79 & 15,413 & 1,038 \\
\hline Turmeric & -0.22 & -3.62 & 0.77 & -0.26 & -4.28 & 0.78 & 0.02 & 2.01 & 0.62 & -0.25 & -4.06 & 0.79 & 16,616 & 1,059 \\
\hline Turmeric raw & 0.12 & 0.87 & 0.59 & 0.05 & 0.39 & 0.59 & -0.07 & -1.36 & 0.73 & 0.21 & 1.49 & 0.60 & 2,972 & 390 \\
\hline Arecanut & -0.34 & -8.47 & 0.72 & -0.32 & -7.89 & 0.74 & -0.03 & -1.95 & 0.66 & -0.32 & -8.32 & 0.75 & 28,493 & 2,443 \\
\hline Cashewnuts & 0.16 & 1.35 & 0.86 & 0.12 & 0.97 & 0.87 & -0.08 & -1.34 & 0.68 & 0.26 & 2.38 & 0.92 & 4,413 & 240 \\
\hline Copra & 0.34 & 5.48 & 0.78 & 0.33 & 5.42 & 0.78 & 0.25 & 15.75 & 0.43 & 0.09 & 1.43 & 0.78 & 14,902 & 1,300 \\
\hline Brinjal & -0.2 & -23.43 & 0.77 & -0.17 & -19.71 & 0.77 & -0.32 & -69.64 & 0.63 & 0.13 & 16.15 & 0.76 & 318,810 & 20,392 \\
\hline Cabbage & -0.21 & -19.06 & 0.75 & -0.18 & -16.38 & 0.75 & -0.2 & -36.53 & 0.67 & -0.01 & -0.69 & 0.78 & 195,821 & 15,264 \\
\hline Cauliflower & -0.39 & -39.42 & 0.73 & -0.36 & -36.55 & 0.75 & -0.31 & -55.11 & 0.67 & -0.1 & -10.53 & 0.74 & 237,422 & 19,578 \\
\hline Okra & -0.05 & -3.31 & 0.72 & -0.04 & -2.79 & 0.73 & -0.14 & -21.82 & 0.53 & 0.1 & 7.40 & 0.72 & 199,390 & 8,818 \\
\hline Onion & 0.11 & 12.52 & 0.77 & 0.11 & 12.05 & 0.80 & 0.21 & 55.44 & 0.64 & -0.1 & -12.52 & 0.82 & 380,829 & 23,809 \\
\hline Potato & -0.47 & -62.54 & 0.81 & -0.41 & -54.97 & 0.82 & -0.48 & -138.94 & 0.56 & 0.01 & 1.26 & 0.84 & 423,796 & 26,281 \\
\hline Tomato & -0.32 & -36.92 & 0.77 & -0.31 & -35.55 & 0.79 & -0.4 & -92.41 & 0.58 & 0.09 & 11.29 & 0.82 & 372,304 & 24,155 \\
\hline Apple & -0.33 & -19.78 & 0.73 & -0.33 & -18.89 & 0.74 & -0.04 & -6.87 & 0.68 & -0.32 & -18.62 & 0.74 & 154,221 & 7,919 \\
\hline Banana & -0.01 & -1.00 & 0.78 & 0 & -0.29 & 0.78 & -0.09 & -18.77 & 0.83 & 0.08 & 5.93 & 0.80 & 173,982 & 9,530 \\
\hline Guava & 0.03 & 1.00 & 0.71 & 0.09 & 2.72 & 0.72 & -0.01 & -0.70 & 0.64 & 0.05 & 1.46 & 0.71 & 43,242 & 2,667 \\
\hline Orange & -0.23 & -6.26 & 0.71 & -0.21 & -5.67 & 0.72 & 0.11 & 5.47 & 0.71 & -0.38 & -10.22 & 0.73 & 39,182 & 3,213 \\
\hline Lemon & -0.26 & -13.79 & 0.73 & -0.23 & -12.04 & 0.74 & -0.64 & -66.70 & 0.65 & 0.4 & 22.25 & 0.77 & 81,897 & 3,755 \\
\hline Lime & -0.04 & -0.79 & 0.75 & -0.05 & -1.04 & 0.78 & -0.33 & -9.13 & 0.84 & 0.34 & 9.93 & 0.83 & 18,727 & 909 \\
\hline Sweet Lime & 0.16 & 5.71 & 0.75 & 0.19 & 6.65 & 0.76 & -0.05 & -5.16 & 0.63 & 0.21 & 7.62 & 0.77 & 75,671 & 2,082 \\
\hline
\end{tabular}


Table 14 Impact of demonetization after 12 weeks (90 days)

The table below presents the coefficient estimates of $\alpha_{3}$ (value), $\beta_{3}$ (arrivals), and $\gamma_{3}$ from commodity specific regressions specified in Equation 1-3. Minimum value represents traded value based on minimum prices reported in data, while maximum value indicates traded value based on maximum prices. The event window used in the regressions is 90 days after demonetization. Standard errors are robust to heteroscedasticity. The values that are boldfaced are significant at $5 \%$ level.

\begin{tabular}{|c|c|c|c|c|c|c|c|c|c|c|c|c|c|c|}
\hline \multirow[b]{2}{*}{ Commodity } & \multicolumn{3}{|c|}{ Minimum value } & \multicolumn{3}{|c|}{ Maximum value } & \multicolumn{3}{|c|}{ Minimum prices } & \multicolumn{3}{|c|}{ Arrivals } & \multirow[t]{2}{*}{ \# of obs. } & \multirow[t]{2}{*}{ Treated Obs. } \\
\hline & $\alpha_{3}$ & t-stat & $\mathrm{R}^{2}$ & $\alpha_{3}$ & t-stat & $\mathrm{R}^{2}$ & $\beta_{3}$ & t-stat & $\mathrm{R}^{2}$ & $\gamma_{3}$ & t-stat & $\mathrm{R}^{2}$ & & \\
\hline Paddy & 0.34 & 26.03 & 0.81 & 0.36 & 27.03 & 0.81 & -0.02 & -12.87 & 0.47 & 0.36 & 27.60 & 0.80 & 391,881 & 31,230 \\
\hline Jowar & -0.25 & -10.81 & 0.57 & -0.24 & -9.88 & 0.57 & -0.03 & -7.56 & 0.51 & -0.22 & -9.61 & 0.56 & 86,952 & 7,560 \\
\hline Bajra & -0.19 & -9.86 & 0.63 & -0.18 & -9.12 & 0.62 & -0.11 & -51.49 & 0.48 & -0.08 & -4.10 & 0.63 & 132,216 & 10,242 \\
\hline Maize & 0.06 & 3.35 & 0.67 & 0.05 & 2.79 & 0.67 & -0.07 & -41.30 & 0.45 & 0.13 & 7.37 & 0.67 & 196,263 & 18,778 \\
\hline Rice & -0.12 & -11.73 & 0.84 & -0.13 & -12.36 & 0.84 & 0.01 & 4.42 & 0.62 & -0.13 & -13.01 & 0.86 & 191,768 & 12,284 \\
\hline Ragi & 0.2 & 3.03 & 0.66 & 0.16 & 2.30 & 0.66 & 0.14 & 11.72 & 0.60 & 0.07 & 1.00 & 0.66 & 15,679 & 1,070 \\
\hline Wheat & 0.05 & 5.01 & 0.69 & 0.05 & 5.42 & 0.69 & 0.02 & 16.78 & 0.44 & 0.03 & 3.05 & 0.69 & 378,030 & 25,234 \\
\hline Cotton & 0.26 & 11.83 & 0.76 & 0.26 & 11.45 & 0.76 & 0.02 & 8.47 & 0.38 & 0.24 & 10.77 & 0.76 & 145,676 & 17,634 \\
\hline Bengal Gram & -0.11 & -5.79 & 0.70 & -0.09 & -4.88 & 0.70 & -0.05 & -13.36 & 0.74 & -0.06 & -3.32 & 0.69 & 133,386 & 8,869 \\
\hline Arhar & -0.35 & -15.41 & 0.63 & -0.31 & -13.63 & 0.63 & -0.53 & -103.14 & 0.61 & 0.19 & 8.31 & 0.61 & 90,592 & 10,979 \\
\hline Soyabean & 0.16 & 8.69 & 0.62 & 0.14 & 7.45 & 0.63 & -0.07 & -32.40 & 0.33 & 0.23 & 12.59 & 0.63 & 168,247 & 17,560 \\
\hline Mustard & 0.17 & 10.33 & 0.69 & 0.17 & 10.27 & 0.68 & -0.12 & -69.24 & 0.45 & 0.29 & 17.72 & 0.68 & 174,197 & 10,070 \\
\hline Groundnut & 0.45 & 15.48 & 0.61 & 0.41 & 13.65 & 0.61 & -0.02 & -5.71 & 0.58 & 0.48 & 16.45 & 0.62 & 89,680 & 6,549 \\
\hline Cumin & 0.29 & 5.36 & 0.64 & 0.28 & 5.06 & 0.65 & -0.01 & -0.98 & 0.66 & 0.3 & 5.55 & 0.65 & 26,371 & 1,319 \\
\hline Coriander seed & 0.08 & 2.09 & 0.69 & 0.07 & 1.89 & 0.71 & -0.13 & -14.81 & 0.48 & 0.22 & 5.84 & 0.72 & 31,510 & 2,704 \\
\hline Dry Chillies & -0.2 & -3.30 & 0.73 & -0.09 & -1.43 & 0.76 & -0.18 & -10.91 & 0.72 & -0.02 & -0.34 & 0.79 & 16,666 & 1,278 \\
\hline Turmeric & -0.22 & -3.86 & 0.77 & -0.26 & -4.57 & 0.78 & 0.01 & 1.17 & 0.62 & -0.24 & -4.15 & 0.79 & 17,888 & 1,307 \\
\hline Turmeric raw & 0.11 & 0.79 & 0.57 & 0.05 & 0.40 & 0.58 & -0.06 & -1.17 & 0.71 & 0.18 & 1.29 & 0.58 & 3,290 & 459 \\
\hline Arecanut & -0.36 & -9.74 & 0.72 & -0.34 & -9.12 & 0.74 & -0.01 & -0.80 & 0.68 & -0.36 & -10.17 & 0.75 & 30,732 & 2,988 \\
\hline Cashewnuts & 0.04 & 0.41 & 0.85 & -0.02 & -0.18 & 0.86 & -0.04 & -0.72 & 0.67 & 0.08 & 0.92 & 0.92 & 4,759 & 302 \\
\hline Copra & 0.4 & 7.16 & 0.78 & 0.41 & 7.18 & 0.78 & 0.33 & 21.53 & 0.43 & 0.08 & 1.44 & 0.78 & 16,063 & 1,592 \\
\hline Brinjal & -0.2 & -25.02 & 0.77 & -0.17 & -21.25 & 0.77 & -0.32 & -76.01 & 0.62 & 0.14 & 17.90 & 0.76 & 338,766 & 24,316 \\
\hline Cabbage & -0.21 & -20.13 & 0.75 & -0.18 & -17.76 & 0.75 & -0.19 & -36.32 & 0.67 & -0.02 & -1.80 & 0.78 & 212,956 & 18,450 \\
\hline Cauliflower & -0.37 & -39.47 & 0.73 & -0.34 & -36.48 & 0.75 & -0.29 & -53.97 & 0.68 & -0.11 & -11.35 & 0.75 & 259,639 & 23,606 \\
\hline Okra & 0.01 & 0.87 & 0.72 & 0.02 & 1.31 & 0.73 & -0.09 & -15.65 & 0.54 & 0.12 & 9.06 & 0.72 & 207,604 & 10,494 \\
\hline Onion & 0.13 & 15.76 & 0.77 & 0.12 & 14.59 & 0.80 & 0.23 & 65.12 & 0.64 & -0.11 & -13.53 & 0.82 & 408,288 & 28,707 \\
\hline Potato & -0.48 & -68.07 & 0.81 & -0.42 & -60.01 & 0.82 & -0.48 & -150.32 & 0.57 & -0.01 & -0.86 & 0.83 & 454,432 & 31,560 \\
\hline Tomato & -0.29 & -35.36 & 0.77 & -0.28 & -34.29 & 0.79 & -0.35 & -82.05 & 0.58 & 0.07 & 8.59 & 0.81 & 399,521 & 29,020 \\
\hline Apple & -0.3 & -18.53 & 0.73 & -0.28 & -17.15 & 0.74 & -0.04 & -6.78 & 0.68 & -0.28 & -17.25 & 0.74 & 163,880 & 9,310 \\
\hline Banana & 0 & 0.14 & 0.78 & 0.01 & 0.92 & 0.78 & -0.07 & -17.32 & 0.83 & 0.08 & 6.65 & 0.80 & 185,214 & 11,387 \\
\hline Guava & 0.1 & 3.21 & 0.71 & 0.15 & 4.69 & 0.72 & 0.01 & 0.99 & 0.64 & 0.1 & 3.07 & 0.71 & 46,964 & 3,160 \\
\hline Orange & -0.23 & -6.39 & 0.71 & -0.21 & -5.79 & 0.72 & 0.1 & 4.86 & 0.71 & -0.36 & -10.02 & 0.73 & 43,071 & 3,846 \\
\hline Lemon & -0.3 & -16.91 & 0.73 & -0.27 & -14.95 & 0.74 & -0.68 & -75.11 & 0.65 & 0.4 & 23.27 & 0.77 & 86,362 & 4,464 \\
\hline Lime & -0.07 & -1.40 & 0.75 & -0.07 & -1.54 & 0.78 & -0.37 & -10.79 & 0.83 & 0.35 & 10.68 & 0.83 & 19,880 & 1,078 \\
\hline Sweet Lime & 0.19 & 7.36 & 0.75 & 0.22 & 8.38 & 0.76 & -0.05 & -5.52 & 0.63 & 0.25 & 9.45 & 0.77 & 79,079 & 2,393 \\
\hline
\end{tabular}




\section{RBI Notifications}




\section{Circulars of the Department of Currency Management}

(November 2016-March 2017)

\begin{tabular}{|c|c|c|c|c|}
\hline S.No. & $\begin{array}{l}\text { DATE OF THE } \\
\text { CIRCULAR }\end{array}$ & CIRCULAR NUMBER & TITLE OF THE CIRCULAR & CONTENT \\
\hline 1. & $08-11-2016$ & $\begin{array}{l}\text { RBI/2016-2017/122 } \\
\mathrm{DCM}(\mathrm{plg}) \text { No.1226/10 } \\
.27 .00 / \\
2016-17\end{array}$ & $\begin{array}{lcr}\text { Withdrawal of } & \text { Legal } \\
\text { Tenders } & & \\
\text { Character of existing } \\
\text { Rs500/-and Rs } & 1000 /- \\
\text { Bank notes } & & \end{array}$ & $\begin{array}{l}\text { 1. Existing bank notes of Rs } 500 /- \text { and Rs } \\
\text { 1000/- (hence referred to as specified } \\
\text { bank notes(SBNs)) cease to exist as legal } \\
\text { tenders from November } 9,2016 \text {. } \\
\text { 2. Urban and State cooperative banks are } \\
\text { allowed to exchange SBNs of aggregate } \\
\text { value of } 4000 /- \text { or below. } \\
\text { 3. Limit of cash withdrawal from bank } \\
\text { account over the counter is Rs } 10,000 /- \\
\text { per day subject to overall limit of Rs } \\
20,000 /- \text { a week from date of notification } \\
\text { to end of business hours of November } 24 \text {, } \\
2016 \text {, after which limit shall be revised. } \\
\text { 4. Withdrawal from ATMs restricted to } \\
\text { RS2000/- } \\
\text { 5. Business correspondents may be allowed } \\
\text { to exchange SBN up to Rs4000/-per } \\
\text { person in case of bank branches. }\end{array}$ \\
\hline 2. & 09-11-2016 & $\begin{array}{l}\text { RBI/2016-2017/115 } \\
\text { DCM(plg)No.1241/10 } \\
.27 .00 / \\
2016-17\end{array}$ & $\begin{array}{lcr}\text { Withdrawal of } & \text { Legal } \\
\text { Tenders } & & \\
\text { Character of existing } \\
\text { Rs500/-and Rs } \\
\text { Bank notes }\end{array}$ & $\begin{array}{l}\text { limit of Rs2000/- per day per card and } \\
20,000 /- \text { in a week across all the channels is } \\
\text { applied to all customers. }\end{array}$ \\
\hline 3. & $10-11-2016$ & $\begin{array}{l}\mathrm{RBI} / 2016-2017 / 123 \\
\mathrm{DCM}(\mathrm{plg}) \mathrm{No} .1251 / 10 \\
.27 .00 / \\
2016-17\end{array}$ & $\begin{array}{l}\text { Withdrawal of Legal } \\
\text { Tender Character of } \\
\text { existing Rs500/- and } \\
\text { Rs1000/-Bank notes-Limit } \\
\text { of Withdrawal of Cash }\end{array}$ & $\begin{array}{l}\text { Interbank transfers, post offices, money } \\
\text { changers in international airports, white label } \\
\text { ATM operators are exempt from over the } \\
\text { counter limits }\end{array}$ \\
\hline 4. & $13-11-2016$ & $\begin{array}{l}\text { RBI/2016-2017/129 } \\
\text { DCM(plg)No.1272/10 } \\
.27 .00 / \\
2016-17\end{array}$ & $\begin{array}{l}\text { Withdrawal of Legal } \\
\text { Tender Character of } \\
\text { existing Rs500/- and } \\
\text { Rs1000/-Bank notes- } \\
\text { Revision in limits }\end{array}$ & $\begin{array}{l}\text { Limit for exchange of SBNs over the counter } \\
\text { increased from existing Rs } 4000 /- \text { to Rs } \\
4,500 /- \\
\text { ATM limit increased from Rs 2000/- to } \\
\text { Rs } 2,500 /- \text { per day. } \\
\text { The weekly limit of withdrawal was increased } \\
\text { from Rs } 20,000 /- \text { to Rs } 24,000 /- \text {. }\end{array}$ \\
\hline 5. & $14-11-2016$ & $\begin{array}{l}\text { RBI/2016-2017/130 } \\
\text { DCM(plg)No.1273/10 } \\
.27 .00 / \\
2016-17\end{array}$ & $\begin{array}{l}\text { Withdrawal of Legal } \\
\text { Tender Character of } \\
\text { existing Rs500/- and } \\
\text { Rs1000/-Applicability of } \\
\text { the Scheme to DCCBs }\end{array}$ & $\begin{array}{l}\text { DCCBs can allow their existing customers to } \\
\text { withdraw money from their accounts up to Rs } \\
24,000 /- \text { per week up to November } 24,2016 \text {. } \\
\text { However no exchange or deposit facility } \\
\text { against SBN should be entertained by them. }\end{array}$ \\
\hline 6. & $14-11-2016$ & $\begin{array}{l}\mathrm{RBI} / 2016-2017 / 131 \\
\mathrm{DCM} \text { (plg)No.1274/10 }\end{array}$ & $\begin{array}{l}\text { Withdrawal of Legal } \\
\text { Tender Character of }\end{array}$ & $\begin{array}{l}\text { Persons with current accounts functional for } \\
\text { the last three months or more are allowed to }\end{array}$ \\
\hline
\end{tabular}




\section{Circulars of the Department of Currency Management}

(November 2016-March 2017)

\begin{tabular}{|c|c|c|c|c|}
\hline & & $\begin{array}{l}.27 .00 / \\
2016-17\end{array}$ & $\begin{array}{l}\text { Specified Bank Notes- } \\
\text { Expanding the distribution } \\
\text { location for deposit and } \\
\text { withdrawal of cash }\end{array}$ & withdraw up to Rs50,000/- per week. \\
\hline 7. & 16-11-2016 & $\begin{array}{l}\mathrm{RBI} / 2016-2017 / 135 \\
\mathrm{DCM}(\mathrm{plg}) \text { No.1287/10 } \\
.27 .00 / \\
2016-17\end{array}$ & $\begin{array}{l}\text { Withdrawal of Legal } \\
\text { Tender Character of } \\
\text { Specified Bank Notes- } \\
\text { Compliance with provision } \\
\text { of } 114 \mathrm{~B} \text { of the Income Tax } \\
\text { Rules } 1962\end{array}$ & $\begin{array}{l}\text { For deposits more than Rs50,000/- in cash a } \\
\text { copy of the PAN card has to be submitted in } \\
\text { case the bank account is not seeded with the } \\
\text { PAN. }\end{array}$ \\
\hline 8. & $17-11-2016$ & $\begin{array}{l}\mathrm{RBI} / 2016-2017 / 139 \\
\mathrm{DCM}(\mathrm{pg}) \mathrm{No} .1302 / 10 \\
27.00 / \\
2016-17\end{array}$ & 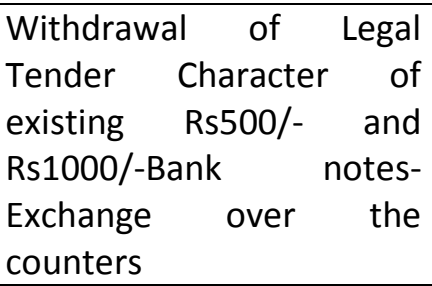 & $\begin{array}{l}\text { Limit of exchange of SBNs in cash, across the } \\
\text { counter of the banks shall be Rs2000/- per } \\
\text { person with effect from November } 18,2016 \text {. }\end{array}$ \\
\hline 9. & 20-11-2016 & $\begin{array}{l}\text { RBI/2016-2017/141 } \\
\text { DCM(plg)No.1304/10 } \\
.27 .00\end{array}$ & $\begin{array}{l}\text { Withdrawal of Legal } \\
\text { Tender Character of } \\
\text { existing Rs500/- and } \\
\text { Rs1000/-Bank notes- } \\
\text { Revision in limits }\end{array}$ & $\begin{array}{l}\text { Banks may continue to dispense Rs } 50 /- \text { and } \\
\text { Rs } 100 /- \text { bank notes through the non - } \\
\text { recalibrated ATMs until they are re-calibrated } \\
\text { with no change in the withdrawal limits. }\end{array}$ \\
\hline 10. & 21-11-2016 & $\begin{array}{l}\mathrm{RBI} / 2016-2017 / 142 \\
\mathrm{DCM}(\mathrm{plg}) \text { No.1317/10 } \\
.27 .00 / \\
2016-17\end{array}$ & $\begin{array}{l}\text { Withdrawal of Legal } \\
\text { Tender Character of } \\
\text { Specified Bank Notes- } \\
\text { Cash Withdrawal Limits }\end{array}$ & $\begin{array}{l}\text { Holders of current / overdraft / cash credit } \\
\text { accounts, which are operational for the last } \\
\text { three months or more, may now withdraw up } \\
\text { to Rs } 50000 \text { /-in cash, in a week. }\end{array}$ \\
\hline 11. & 21-11-2016 & $\begin{array}{l}\mathrm{RBI} / 2016-2017 / 146 \\
\mathrm{DCM}(\mathrm{plg}) \text { No.1323/10 } \\
.27 .00 / \\
2016-17\end{array}$ & $\begin{array}{l}\text { Withdrawal of Legal } \\
\text { Tender Character of } \\
\text { existing Rs500/- and } \\
\text { Rs1000/-Bank notes- } \\
\text { Revisions }\end{array}$ & $\begin{array}{l}\text { Farmers may be allowed to draw up to Rs } \\
25000 /- \text { per week in cash from their loan } \\
\text { (including Kisan Credit Card limit) or KYC } \\
\text { compliant deposit accounts. } \\
\text { Traders registered with APMC markets / } \\
\text { mandis are allowed to withdraw, in cash, Rs } \\
50,000 /- \text { in a week from their KYC complaint } \\
\text { current account subject to certain terms and } \\
\text { conditions. }\end{array}$ \\
\hline 12. & $22-11-2016$ & $\begin{array}{l}\mathrm{RBI} / 2016-2017 / 148 \\
\mathrm{DCM} \text { (plg)No.1345/10 } \\
.27 .00 / \\
2016-17\end{array}$ & $\begin{array}{l}\text { Making cash available for } \\
\text { Rabi Crop Season - } \\
\text { Advisory to banks }\end{array}$ & $\begin{array}{l}\text { To ensure adequate credit for farmers in the } \\
\text { Rabi season, an estimated Rs } 35,000 /- \text { crore } \\
\text { would be required by the DCCBs for sanctions } \\
\text { and disbursement of crop loan to the farmers } \\
\text { at the rate Rs } 10,000 /- \text { crore per week. } \\
\text { NABARD would utilize its own Cash Credit } \\
\text { limits up to about Rs } 23,000 /- \text { crore to enable } \\
\text { DCCBs to disburse the required crop loans to } \\
\text { PACS and farmers. }\end{array}$ \\
\hline 13. & 23-11-2016 & $\begin{array}{l}\text { RBI/2016-2017/151 } \\
\text { DCM(plg)No.1351/10 } \\
.27 .00 / 2016-17 \\
\end{array}$ & $\begin{array}{l}\text { Deposit of Specified } \\
\text { Banknotes (SBN) in Small } \\
\text { Saving Schemes }\end{array}$ & $\begin{array}{l}\text { Banks are advised not to accept SBNs for } \\
\text { deposits in Small Savings Scheme with } \\
\text { immediate effect. }\end{array}$ \\
\hline 14. & 24-11-2016 & $\mathrm{RBI} / 2016-2017 / 155$ & Discontinuation of over & No over the counter exchange (in cash) of \\
\hline
\end{tabular}




\section{Circulars of the Department of Currency Management}

(November 2016-March 2017)

\begin{tabular}{|c|c|c|c|c|}
\hline & & $\begin{array}{l}\text { DCM(plg)No.1391/10 } \\
.27 .00 / \\
2016-17\end{array}$ & $\begin{array}{l}\text { the Counters Exchanges of } \\
\text { SBN }\end{array}$ & $\begin{array}{l}\text { SBNs will be permitted after midnight of } \\
\text { November 24, 2016, instead SBNs can be } \\
\text { deposited in the account. }\end{array}$ \\
\hline 15. & $25-11-2016$ & $\begin{array}{l}\text { RBI/2016-2017/158 } \\
\text { DCM(plg)No.1424/10 } \\
.27 .00 / \\
2016-17\end{array}$ & $\begin{array}{l}\text { Withdrawal of cash - } \\
\text { Weekly limit }\end{array}$ & $\begin{array}{l}\text { Cash withdrawals (including ATM } \\
\text { withdrawals) allowed up to Rs 24,000/- per } \\
\text { week, till further instructions. }\end{array}$ \\
\hline 16. & $28-11-2016$ & $\begin{array}{l}\text { RBI/2016-2017/163 } \\
\text { DCM(plg)No.1437/10 } \\
.27 .00 / \\
2016-17\end{array}$ & $\begin{array}{l}\text { Withdrawal of cash from } \\
\text { bank deposit accounts - } \\
\text { Relaxation }\end{array}$ & $\begin{array}{l}\text { Withdrawal of deposits made in current legal } \\
\text { tender notes on or after November } 29,2016 \\
\text { beyond the current limits; preferably, } \\
\text { available higher denominations bank notes of } \\
\text { Rs } 2000 \text { /-and Rs 500/- are to be issued for } \\
\text { such withdrawals. }\end{array}$ \\
\hline 17. & 29-11-2016 & $\begin{array}{l}\mathrm{RBI} / 2016-2017 / 165 \\
\mathrm{DCM} \text { (plg)No.1450/10 } \\
.27 .00 / \\
2016-17\end{array}$ & $\begin{array}{l}\text { Accounts under PMJDY - } \\
\text { Precautions }\end{array}$ & $\begin{array}{l}\text { Fully KYC compliant account holders may be } \\
\text { allowed to withdraw Rs } 10,000 /- \text { from their } \\
\text { account, in a month, while Non KYC compliant } \\
\text { account holders may be allowed to withdraw } \\
\text { Rs 5,000/- per month from the amount } \\
\text { deposited through SBNs after November 09, } \\
2016 \text { within the overall ceiling of Rs } 10,000 /-.\end{array}$ \\
\hline 18. & $19-12-2016$ & $\begin{array}{l}\text { RBI/2016-2017/189 } \\
\text { DCM(plg)No.1859/10 } \\
.27 .00 / \\
2016-17\end{array}$ & $\begin{array}{l}\text { Withdrawal of Legal } \\
\text { Tender Character of } \\
\text { existing Rs500/- and } \\
\text { Rs1000/-Bank notes(SBN)- } \\
\text { Deposit of Specified Bank } \\
\text { Notes into bank accounts }\end{array}$ & $\begin{array}{l}\text { Restrictions on deposits of SBNs into bank } \\
\text { accounts } 2016 \text { are as indicated below: } \\
\text { a. Tenders of SBNs in excess of Rs5000/- into } \\
\text { a bank account will be received for credit } \\
\text { only once in KYC complaint accounts } \\
\text { during the remaining period till December } \\
\text { 30, } 2016 \text { after due inspection. } \\
\text { b. Tenders of SBNs up to Rs } 5000 /- \text { in value } \\
\text { received across the counter will allowed } \\
\text { to be credited to bank accounts in the } \\
\text { normal course until December } 30,2016 \text {. } \\
\text { c. Non KYC compliant credits may be } \\
\text { restricted up to Rs } 50,000 /-. \\
\text { d. The equivalent value of SBNs tendered } \\
\text { may be credited to an account maintained } \\
\text { by the tenderer or a third party account at } \\
\text { any bank in accordance with standard } \\
\text { banking procedure and on production of } \\
\text { valid proof of Identity. } \\
\text { e. The above restrictions shall not apply to } \\
\text { tenders of SBNs for the purpose of } \\
\text { deposits under the Taxation and } \\
\text { Investment Regime for the Pradhan } \\
\text { Mantri Garib Kalyan Yojana, } 2016 \text {. }\end{array}$ \\
\hline 19. & $30-12-2016$ & $\begin{array}{l}\text { RBI/2016-2017/204 } \\
\mathrm{DCM} \text { (plg)No.2142/10 } \\
.27 .00 /\end{array}$ & $\begin{array}{l}\text { Cash Withdrawals from } \\
\text { ATMs -enhancement of } \\
\text { Daily limits }\end{array}$ & $\begin{array}{l}\text { Cash withdrawal from ATMs has been } \\
\text { increased with effect from January 01,2017, } \\
\text { from the existing Rs } 2500 /- \text { to Rs } 4500 /- \text { per }\end{array}$ \\
\hline
\end{tabular}




\section{Circulars of the Department of Currency Management}

(November 2016-March 2017)

\begin{tabular}{|c|c|c|c|c|}
\hline & & 2016-17 & & day per card \\
\hline 20. & 16-01-2017 & $\begin{array}{l}\text { RBI/2016-2017/213 } \\
\mathrm{DCM} \text { (plg)No.2559/10 } \\
.27 .00 / \\
2016-17\end{array}$ & $\begin{array}{l}\text { Enhancement of } \\
\text { withdrawal limits from } \\
\text { ATMs and Current } \\
\text { Accounts }\end{array}$ & $\begin{array}{l}\text { Limit on withdrawal from ATMs has been } \\
\text { enhanced from current limit of Rs } 4,500 /- \text { to } \\
\text { Rs } 10,000 /- \text { per day per card and from } \\
\text { RS50,000/- to RS1,00,00,/- per week for } \\
\text { cuurent, Overdraft and cash credit accounts. }\end{array}$ \\
\hline 21. & 30-01-2017 & $\begin{array}{l}\mathrm{RBI} / 2016-2017 / 217 \\
\mathrm{DCM} \text { (plg)No.2905/10 } \\
.27 .00 / \\
2016-17\end{array}$ & $\begin{array}{l}\text { Limits on Cash } \\
\text { withdrawals from Banks } \\
\text { accounts and ATMs - } \\
\text { Restoration of status quo } \\
\text { ante }\end{array}$ & $\begin{array}{l}\text { Limits placed on cash withdrawal from Saving } \\
\text { Bank accounts will continue till February 01, } \\
2017 \text { while limits on Current Accounts/ Cash } \\
\text { Credit Accounts/Overdraft Accounts stand } \\
\text { withdrawn. }\end{array}$ \\
\hline 22. & $08-02-2016$ & $\begin{array}{l}\mathrm{RBI} / 2016-2017 / 224 \\
\mathrm{DCM} \text { (plg)No.3107/10 } \\
.27 .00 / \\
2016-17\end{array}$ & $\begin{array}{l}\text { Removal of limits of } \\
\text { withdrawal of cash from } \\
\text { Savings Bank Accounts }\end{array}$ & $\begin{array}{l}\text { Limit on cash withdrawals from Savings Banks } \\
\text { Accounts will be enhanced to Rs } 50,000 /- \text { per } \\
\text { week ( from current limit of Rs } 24,000 /- \text { per } \\
\text { week) and no such limit effective March 13, } \\
2017 \text {. }\end{array}$ \\
\hline
\end{tabular}

